Universidade de Brasília

Instituto de Ciências Biológicas

Departamento de Biologia Celular

Programa de Pós-Graduação em Biologia Molecular

Engenharia metabólica de Saccharomyces cerevisiae para aproveitamento de xilose na produção de etanol lignocelulósico

Bárbara Gomes Paes

Brasília 
Universidade de Brasília

Instituto de Ciências Biológicas

Departamento de Biologia Celular

\title{
Engenharia metabólica de Saccharomyces cerevisiae para aproveitamento de xilose na produção de etanol lignocelulósico
}

\author{
Dissertação de Mestrado apresentada ao \\ Programa de Pós-Graduação em Biologia \\ Molecular do Instituto de Ciências \\ Biológicas da Universidade de Brasília \\ como requisito parcial para obtenção do \\ título de Mestre em Biologia Molecular.
}

\author{
Aluna: Bárbara Gomes Paes \\ Orientadora: Prof. ${ }^{a}$ Lídia Maria Pepe de Moraes \\ Coorientador: Dr. João Ricardo Moreira de Almeida \\ Brasília
}


À minha avó Mônica. 


\section{AGRADECIMENTOS}

Antes de tudo, à minha família, que foi fortaleza quando eu já não tinha forças, foram energia quando eu precisei recarregar, foram ouvidos quando eu precisava falar, foram ombros quando eu precisava chorar. Obrigada por me darem a herança mais valiosa que alguém pode ter, muitas vezes com sacrifícios, mas sempre com muito amor.

Ao querido (co)orientador João Ricardo, pela confiança e oportunidade de desenvolver este projeto em seu grupo de trabalho. Por todas as lições, disponibilidade, e todas as vezes que me disse para ter calma, muita calma. Pela paciência, e especialmente por acreditar em mim até quando eu mesma duvidei, muito obrigada.

A minha orientadora Lídia, pela orientação e por acreditar que eu faria um bom trabalho. À Viviane Reis, pela colaboração e disponibilidade na realização dos ensaios enzimáticos.

A Ana Paula Ribeiro, conselheira, consultora, salvadora, ajuda para todos os momentos! Amiga que me ensinou tanto, brigou e me abrigou, e me iluminou tantas vezes com o seu conhecimento. Ao Henrique, sempre disponível para ajudar, que me salvou em especial nos momentos mais difíceis. À Carol e à Talita, que me ajudaram na bancada e fora dela, que dividem comigo vícios adoráveis, histórias incríveis, e risadas intermináveis.

A todos os amigos do grupo ou que já passaram por ele, que dividiram não apenas bancada, meios e soluções comigo, mas também risadas e histórias, e gostam de mim mesmo com as minhas duzentas canetas e mania de organização. Saibam que eu sei que não é fácil me aguentar! Um agradecimento especial à Samantha, que foi minha fiel escudeira, e se me permite, uma pupila e amiga da qual me orgulho!

Obrigada a todos vocês queridos, que tornaram os dias no LGB mais alegres e leves. Sem vocês esta jornada seria infinitamente mais difícil, e certamente sem a mesma graça. Aos analistas do LGB e LPB, sempre dispostos a ajudar. Em especial à Betúlia, que me ajudou a enxergar a beleza do sequenciamento.

Aos amigos da salinha da pós, pelos cafés, lanches, risadas, pelo encorajamento, e por dividirem essa experiência nada simples que é a pós-graduação.

A tantos amigos do Lab MOA, que estão longe, mas foram todos importantes companheiros e antigos mentores. Aos amigos da graduação e a sumida Lena. Sem vocês essa jornada nem teria começado.

As professoras Ildinete e Cynthia, minhas fadas madrinhas, que me salvaram e deram bons conselhos tantas (e tantas) vezes. Vocês me inspiram. Obrigada por cuidarem e acreditarem em mim. 
A Thais 'Japa' Ziober, que mesmo de longe sempre me apoiou, e me perguntou o que eu tinha almoçado. Ao Bruno 'Baiano' Amui, por não desistir de mim por todas as vezes que eu disse "não dá, estou/vou pro lab, e por tentar solucionar meus problemas insolucionáveis (por favor, se forme). Ao Álvaro e à Dri, companheiros de aventuras e divagações, que entraram nessa saga de mestrado, em que dividimos momentos de alegria e dúvida, regados à cafés e cervejas e música boa. À Verô e Igor, que numa amizade recente e surpreendente foram fundamentais neste processo. Ao meu Pedaço querido de Deborah. Pelos papos cabeças e fúteis, pelos conselhos, cervejas, pelos bons momentos e por aparecerem na minha vida!

A todos os meus amigos, os lymdos, os loucos, e a todos aqueles que o sol toca. Aos amigos do Núcleo de PesquisaS pela motivação. Aos amigos perto, amigos longe. Vocês que foram meus psicólogos, meus conselheiros, meus companheiros de aventuras, aguentaram minhas crises, me distraíram, viajaram comigo ou me abrigaram em viagens, me aconselharam, ouviram infinitas vezes eu explicar o meu projeto, e especialmente me amaram durante todo este processo. Eu sei que não foi fácil me aguentar, e por isso e por tudo eu sou profundamente grata.

A Ceres e à cerveja, inspiração e solução, e que empresta seu nome à minha levedura. Com certeza não teria chegado aqui sem estas.

Aos podcasts: Nerdcast, MRG, PDG, Scicast, Rapaduracast, TED Radio Hour, Invisibilia, Seth Andrews, que foram companhia indispensável nos momentos mais solitários, durante as longas horas de lavagem de vidraria e preparação de materiais, e em meus finais de semana no laboratório.

Ao Dream Theater, Pink Floyd, Led Zeppelin, ACDC, Metallica, Janis Joplin, Dear Hunter dentre tantos outros, e especialmente ao Queen, que me inspiraram, me acompanharam, e foram a trilha sonora de tantos momentos.

A CAPES e CNPq pelo apoio financeiro.

A EMBRAPA Agroenergia que me deu todo apoio, oportunidade e estrutura de desenvolver o projeto, foi meu laboratório e casa pelos dois últimos anos.

A sociedade brasileira.

E a todos que, de uma forma ou de outra, se sintam parte deste processo (ou não);

o meu sincero muito obrigada. 
"Try not. Do... or do not. There is no try"

Mestre Yoda 


\section{ÍNDICE}

ÍNDICE DE FIGURAS

LISTA DE ABREVIATURAS IV

RESUMO V

ABSTRACT VII

INTRODUÇ̃̃O 8

1. Petróleo Como fonte de energia mundial

2. BIOCOMBUSTÍVEIS: ETANOL

2.1. O CENÁRIO BRASILEIRO

2.2. PRODUÇão DE ETANOL: PRIMEIRA E SEGUNDA GERAÇÕES

3. COMPOSIÇÃO DA BIOMASSA

3.1. MiCRORGANISMOS E VIAS DO CATABOLISMO DE XILOSE

4. SACCHAROMYCES CEREVISIAE

4.1. ENGENHARIA METABÓLICA DE S. CEREVISIAE

5. XI PIROMYCES

\begin{tabular}{lr} 
OBJETIVOS & 21 \\
\hline
\end{tabular}

MATERIAIS E MÉTODOS

1. Microrganismos 22

2. GENES 22

3. OLIGONUCLEOTÍDEOS 22

4. VETORES

5. ENZIMAS $\quad 24$

5.1. ENZIMAS DE RESTRIÇÃO 24

5.2. TAQ POLIMERASE 24

5.3. PFU POLIMERASE 24

5.4. T4 DNA LIGASE 24

5.5. RNASE A 24

6. MARCADOR MOLECULAR 25

7. SOLUÇÕES

7.1. ANTIBIÓTICOS 25

7.2. ANÁLISE EM GEL DE AGAROSE

7.3. SOLUÇ̃̃O DE AMINOÁCIDOS 25

7.4. SOluÇão PARA ANÁlise EM HPLC (CROMATOGRAFIA LÍQUidA DE ALTA PERFORMANCE) 25

7.5. SOLUÇão DE SAIS (10X) 26

7.6. SOLUÇão DE VITAMINAS (1000X) 26

7.7. SOLUÇão de ELEMENTOS TRAÇO (1000X) 26

7.8. ERGOSTEROL/TWEEN $80 \quad 27$

8. Meios De CUltura

8.1. Meios DE CUltura PARA BACTÉRIA 27

8.2. MeIOS DE CULTURA PARA LEVEDURA 27

9. Protocolos 29

9.1. PCR (POLIMERASE CHAIN REACTION) 29 
9.2. ELETROFORESE EM GEL DE AGAROSE 30

9.3. RESTRIÇÕES 30

9.4. LIGAÇÃO 30

9.5. PURIFICAÇÃO DE FRAGMENTO DE DNA EM GEL DE AGAROSE 31

9.6. PURIFICAÇÃO DE PLASMÍDEOS E PCR 31

9.7. PREPARO de CÉlULAS ElETROCOMPETENTES 31

9.8. PREPARO E TRANSFORMAÇÃo DE LEVEDURA 31

9.9. TRANSFORMAÇÃO DE BACTÉRIA POR ELETROPORAÇÃO (E. COLI) 31

9.10. EXTRAÇÃO DE DNA PLASMIDIAL POR LISE ALCALINA (MIDIPREPARAÇÃO DE BACTÉRIA) 31

9.11. EXTRAÇÃO DE DNA PLASMIDIAL (MINIPREPARAÇÃO DE LEVEDURA) 32

10. CURVA DE CRESCIMENTO EM TUBO DE ENSAIO

11. FERMENTAÇÃO EM ERLENMEYER

12. FERMENTAÇÃO EM BIORREATOR

13. CONDICIONAMENTO DE LEVEDURAS

14. CuRa de LeVEduras

14.1. TESTE DE CURA

14.2. TESTE FISIOLÓGICO DE CONFIRMAÇÃO DA CURA

15. ANÁLISE DE METABÓLITOS - HPLC

16. ATIVIDADE ENZIMÁTICA

16.1. PREPARO DE EXTRATO CELULAR

16.2. ATIVIDADE ENZIMÁTICA 36

16.3. NORMALIZAÇÃO POR CURVA DE BRADFORD 36

16.4. ANÁLISE ESTATÍSTICA 36

17. SEQUENCIAMENTO DA XIPIRO CONDICIONADA

17.1. PREPARAÇÃO DE AMOSTRAS PARA SEQUENCIAMENTO 37

RESULTADOS

1. CONSTRUÇão DE LINHAGENS DE SACCHAROMYCES CEREVISIAE CAPAZES DE CONSUMIR XILOSE $\quad \mathbf{3 8}$

1.1. CLONAGEM DOS GENES XKS1 E XYLA 38

1.2. TRANSFORMAÇÃO EM DE LEVEDURA $\quad 40$

1.3. MELHORAMENTO GENÉTICO POR EVOLUÇÃO ADAPTATIVA 42

1.4. AVALIAÇÃO DO PERFIL DE CRESCIMENTO E CAPACIDADE FERMENTATIVA DAS LINHAGENS CONSTRUÍDAS 48

1.5. TESTE DE ATIVIDADE ENZIMÁTICA

2. SEQUENCIAMENTO DA XIPIRO CONDICIONADA

2.1. PREPARAÇÃO DE AMOSTRAS PARA SEQUENCIAMENTO 59

2.2. SEQUENCIAMENTO DAS AMOSTRAS 60

3. INVESTIGAÇÃO DA MELHORIA DAS LINHAGENS CONDICIONADAS E GERAÇÃO DE LINHAGENS DE SELEÇÃO

3.1. OBTENÇÃO DE LINHAGENS CURADAS

3.2. CONFIRMAÇÃO DA CURA POR TESTE FISIOLÓGICO E PCR 63

3.3. RETRANSFORMAÇÃO DA LINHAGEM LC7 66

\begin{tabular}{lr} 
DISCUSSÃO & 68 \\
\hline
\end{tabular}

CONCLUSÕES

\begin{tabular}{lr} 
PERSPECTIVAS & $\mathbf{7 7}$ \\
\hline
\end{tabular} 


\section{ÍNDICE DE FIGURAS}

Figura 1: Composição percentual da biomassa lignocelulósica, com seus principais monômeros constituintes.

Figura 2: Vias metabólicas de catabolismo da xilose: $\mathrm{A}=$ oxirredução e $\mathbf{B}=$ isomerização.

Figura 3: Confirmação da amplificação dos genes XIPiro $(1,4 \mathrm{~kb})$ e XK $(1,8 \mathrm{~kb}) .38$

Figura 4: Estratégia de construção do plasmídeo p424-XI.

Figura 5 Estratégia de clonagem para a construção do plasmídeo p426-XK. 40

Figura 6: Teste de crescimento das leveduras transformantes geradas. $\quad 42$

Figura 7: Teste de crescimento entre transformantes isolados originais.

Figura 8: Curva de crescimento de seis colônias isoladas das linhagens obtidas a partir de cada população de condicionadas.

Figura 9: Confirmação da presença do gene XIPiro nos isolados condicionados 46

Figura 10: Confirmação da presença do gene XK nos isolados condicionados. 47

Figura 11: Teste de crescimento das linhagens transformantes originais econdicionadas.

Figura 12: Teste de crescimento com inóculo inicial alto das linhagens transformantes Originais e Condicionadas.

Figura 13: Cofermentação de glicose e xilose pelas linhagens L2XI Original e Condicionada (A, B) em biorreator em anaerobiose.

Figura 14: Atividade enzimática de xiluloquinase das linhagens transformantes Originais e Condicionadas. As barras indicam o desvio padrão das amostras.

Figura 15: PCR de confirmação da presença do gene XIPiro das colônias de bactéria transformada com DNA extraído das leveduras.

Figura 16: Alinhamento entre as sequencias de XIPiro das leveduras condicionadas L2XI, L7XIФ, L7XIXK.

Figura 17: Teste de crescimento das leveduras condicionadas curadas.

Figura 18: Avaliação do crescimento das leveduras curadas.

Figura 19: PCR de colônia das leveduras curadas LC2, LCФ e L7XIXK. $\quad 65$

Figura 20: Comparação entre teste de crescimento da linhagem retransformada LC-RT7 (A) e a condicionada L7XIXK (B).

Figura 21: Sequência gerada a partir da montagem de contigs do sequenciamento do plasmídeo p424-XI.

Figura 22: Sequência gerada a partir montagem de contigs do sequenciamento da PCR de XIPiro utilizando plasmídeo extraído da levedura L2XI Condicionada. 
Figura 23: Sequência gerada a partir montagem de contigs do sequenciamento de XIPiro dos plasmídeos A B, C, D e E extraídos das colônias de E. coli transformadas com plasmídeo da levedura L7XIФ Condicionada.

Figura 24: Sequência gerada a partir montagem de contigs do sequenciamento de XIPiro dos plasmídeos A B, C, D e F extraídos das colônias de $E$. coli transformadas com plasmídeo da levedura L7XIXK Condicionada.

Figura 25: Alinhamento entre sequências obtidas, dos plasmídeos p424-XI, L2XI, L7XIФ e L7XIXK Condicionadas. 


\section{ÍNDICE DE TABELAS}

Tabela 1: Composição percentual de resíduos lignocelulósicos agroindustriais. 14

Tabela 2: Linhagens de microrganismos utilizados neste trabalho.

Tabela 3: Oligonucleotídeos utilizados na construção de cassetes de expressão. 23

Tabela 4: Vetores em $E$. coli e $S$. cerevisiae.

Tabela 5: Linhagens de $S$. cerevisiae transformantes geradas no trabalho, pela inserção dos vetores construídos.

Tabela 6: Concentração final de xilose consumida e de produtos formados. $\quad 50$

Tabela 7: Taxa de crescimento e rendimento em gramas de produto formado por grama de substrato (xilose) consumido em fermentação aeróbia de baixa OD600 inicial.

Tabela 8: Concentração final de xilose consumida e produtos formados, em

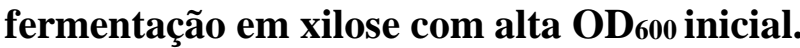

Tabela 9: Rendimento em gramas de produto formado por grama de substrato (xilose) consumido em fermentação aeróbia de alta OD600 inicial.

Tabela 10: Produtividade específica de produto em fermentação de xilose com alta OD600 inicial.

Tabela 11: Concentração final de açúcares consumidos e produtos formados por cofermentação em biorreator.

Tabela 12: Taxa de crescimento, balanço de carbono e rendimento em gramas de produto formado por grama de açúcar consumido de cofermentação em biorreator.

Tabela 13: Produtividade específica de produtos formados por cofermentação em biorreator.

Tabela 14: Comparação entre taxas de crescimento de Saccharomyces cerevisiae (linhagens isogênicas de CEN.PK) expressando XI de Piromyces sp em fermentação aeróbica de xilose como fonte de carbono. 


\section{LISTA DE ABREVIATURAS}

${ }^{\circ} \mathrm{C}$

ADP

ATP

BSA

$\mathrm{CO}_{2}$

dNTP

EDTA

$\mathrm{H}_{2} \mathrm{SO}_{4}$

$\mathrm{HCl}$

HPLC

КОH

LB

MCS

$\mathrm{Mg}_{2}$

$\mathrm{MgCl}_{2}$

$\mathrm{Mn} 2$

$\mathrm{NaCl}$

NAD+/NADH

NADP+/NADPH

$\mathrm{NaOH}$

OD600

PCR

Proálcool

SB

XDH

XI

XK

XR

Y-PER

YNB

YPD

YPX
Graus Celsius

Adenosina bi fosfato

Adenosina tri fosfato

Albumina do soro bovino (bovine serum albumin)

Dióxido de Carbono

Desoxirribonucleotídeos Fosfatados (deoxyribonucleotide

triphosphate)

Ácido Etileno-diamino-tetra-acético

Ácido Sulfúrico

Ácido Clorídrico

Cromatografia líquida de alta performance (high performance

liquid chromatography)

Hidróxido de Potássio

Meio de cultura Luria-Bertani

Sítios de clonagem múltipla (multiple cloning sites)

Complexo binuclear de magnésio

Cloreto de Magnésio

Complexo binuclear de manganês

Cloreto de Sódio

Nicotinamida adenina dinucleotídeo

Nicotinamida adenina dinucleotídeo fosfato

Hidróxido de Sódio

Densidade ótica à 600nm (densidade celular)

Reação em cadeia de polimerase (polymerase chain reaction)

Programa Nacional do Álcool

Tampão ácido bórico e sódio

Xilitol Desidrogenase

Xilose isomerase

Xiluloquinase

Xilose Redutase

Reagente de extração de proteína de levedura

Base nitrogenada para levedura (yeast nitrogen base)

Extrato de levedura, peptona, dextrose (yeast peptone

dextrose)

Extrato de levedura, peptona, xilose (yeast peptone xylose) 


\section{RESUMO}

O aumento na demanda por energias sustentáveis impulsiona o desenvolvimento de estratégias biotecnológicas para a produção de biocombustíveis. Neste contexto, o aproveitamento eficiente da biomassa lignocelulósica como matéria prima é fundamental para a produção de etanol de segunda geração. A levedura Saccharomyces cerevisiae, organismo mais utilizado na produção industrial de bioetanol, é incapaz de utilizar pentoses, como a xilose, que é o segundo açúcar mais abundante em algumas biomassas. Neste trabalho, plasmídeos epissomais foram construídos para expressão de genes codificadores para xilose isomerase (XI) de Piromyces sp. e xiluloquinase (XK) de $S$. cerevisiae. As linhagens laboratoriais de $S$. cerevisiae CEN.PK 113.14A Atrp1-289 (L2) e CEN.PK 113.3C Atrp1-289, Aura-52 (L7) foram transformadas com os plasmídeos gerados. Desta forma, foram construídas linhagens recombinantes de $S$. cerevisiae expressando XI isoladamente (L2XI) ou em conjunto com XK (L7XIXK). Uma terceira linhagem, L7XIФ, expressando XI e com o segundo plasmídeo vazio foi construída como controle. A linhagem L7XIXK apresentou melhores taxas fermentativas que as demais linhagens, confirmando o efeito positivo da expressão de XK. As linhagens L2XI, L7XIФ e L7XIXK obtidas foram submetidas a um processo de condicionamento em meio seletivo contendo xilose como única fonte de carbono. Ao final do condicionamento, quando comparadas com as originais, apresentaram menor fase lag de crescimento e maior taxa de crescimento, maior consumo de xilose (entre 1,8 e 18,5 vezes) e rendimento de etanol (47\% para L7XIXK), concomitante à diminuição do rendimento de xilitol (entre $87,6 \%$ e 91,8\%). A linhagem L2XI, investigada anaerobicamente, também apresentou aumento no consumo específico de xilose $(49,8 \%)$, rendimento de etanol (19\%) e redução no rendimento de xilitol (75\%). As linhagens condicionadas foram submetidas então a um processo de cura para remoção dos plasmídeos. Uma das linhagens obtidas, LC7, derivada de L7XIXK perdeu a capacidade de crescer em meio mínimo, indicando a perda dos plasmídeos. Entretanto o gene para XI ainda foi identificado na levedura. A retransformação desta levedura curada com os plasmídeos originais demonstrou que as melhorias da levedura condicionada podem estar associadas a mutações fora do plasmídeo. Esta linhagem curada tem grande potencial 
para desenvolvimento de uma linhagem de seleção para novas enzimas da via do catabolismo de xilose.

Palavras-chave: Xilose isomerase, Saccharomyces cerevisiae, Engenharia metabólica, Etanol. 


\begin{abstract}
The increasing demand for sustainable energy drives the development of biotechnological strategies for the production of biofuels. In this context, efficient utilization of lignocellulosic biomass as feedstock is essential for the production of second generation biofuels. The yeast $S$. cerevisiae, main organism utilized in the industrial production of bioethanol, is unable to use pentoses, such as xylose, which is the second most abundant sugar in some biomasses. In this work, multi-copy plasmids were constructed for the expression of genes coding xylose isomerase (XI) from Piromyces sp. and xylulokinase (XK) from $S$. cerevisiae. The laboratory strains of $S$. cerevisiae CEN.PK 113.14A Atrp1-289 (L2) and CEN.PK 113.3C Atrp1-289, Aura52 (L7) were transformed with the generated plasmids. Thus, recombinant strains of S. cerevisiae expressing solely XI (L2XI), or combined with XK (L7XIXK) were obtained. A third strain, L7XIФ, expressing XI and with an empty second plasmid, was constructed as control. The L7XIXK strain presented better fermentative rates than the other strains, confirming the positive effect of XK expression. The obtained strains L2XI, L7XIФ and L7XIXK underwent a conditioning process in selective medium with xylose as sole carbon source. At the end of the process, when compared to the original strains, conditioned strains presented shorter lag growth phase, and increased growth rate, increased xylose consumption (1,8 to 18,5 fold) and ethanol yield (47\% for L7XIXK), along with reduction in xylitol production (between 87,6 and 91,8\%). The strain L2XI was investigated under anaerobic conditions and also has presented improved xylose specific consumption (49,8\%), ethanol yield (19\%) and xylitol reduction (75\%). The conditioned strains underwent a curing process, in order to remove the plasmids. One of the obtained strains, LC7, which derived from L7XIXK, has lost its ability to grow on minimal medium, a result consistent with the loss of plasmids. However the XI gene was still identified in the yeast. The retransformation of this curated yeast with the originally constructed plasmids showed that the improvements observed in conditioned strains may be associated with mutations outside of the plasmids. The curated strain has a great potential for the development of a screening strain for new enzymes of the xylose catabolic pathway.
\end{abstract}

Keywords: Xylose isomerase, Saccharomyces cerevisiae, Metabolic engineering, Ethanol. 


\section{INTRODUÇÃO}

\section{Petróleo como fonte de energia mundial}

O desenvolvimento industrial e social no século $\mathrm{XX}$ ocorreu em boa parte devido ao desenvolvimento da indústria petroquímica. O petróleo se tornou uma fonte de energia de baixo custo, abundante e eficiente, tanto para a indústria, agricultura, e na produção de produtos químicos derivados. Adentramos o século XXI, portanto, cada vez mais dependentes de combustíveis fósseis (ANP, 2014).

Combustíveis fósseis atualmente representam aproximadamente $80 \%$ da energia produzida no mundo, incluindo petróleo, carvão e gás natural (HÖÖK; TANG, 2013). Ainda que tenha havido um crescimento da produção de petróleo de 85,7 milhões de barris por dia em 2009 para 90,88 milhões em 2013, a demanda aumentou quase proporcionalmente, de 84,97 para 91,19 milhões de barris por dia no mesmo período (EIA, 2014a). E a demanda mundial de energia está calculada para crescer cerca de 37\% até 2040 (IEA, 2014).

A utilização de combustíveis fósseis tem suscitado várias discussões. Além de disputas geopolíticas e crises econômicas (HE; WANG; LAI, 2010), também a crescente preocupação com os efeitos negativos dos derivados de petróleo para o meio ambiente, como a emissão de gases que contribuem para o efeito estufa (PETERSON; CONNOLLEY; FLECK, 2008), e o dano causado por contaminações subterrâneas e eventuais derramamentos. Adicionalmente, o distante, porém inevitável fato de que o petróleo tem disponibilidade limitada, têm incentivado estudos para o desenvolvimento de combustíveis alternativos (HÖÖK; TANG, 2013).

Ainda que a preocupação com o esgotamento do petróleo e com a utilização de combustíveis sustentáveis pareça uma discussão moderna, Henry Ford, fundador da Ford Motors Company, em 1916, já fazia previsões para o fim da gasolina durante a Primeira Guerra Mundial, apostando no etanol como substituto:

A gasolina está indo; o álcool, chegando [...]. E olhe que está chegando para ficar, pois é uma fonte ilimitada. E é bom nós nos prepararmos para recebê-la. O mundo espera por um substituto para a gasolina. E, quando ele chegar, não haverá mais gasolina; dentro em pouco, os preços da gasolina subirão tanto que será inviável consumi-la como combustível de motor. Não tarda o dia em que cada tambor de gasolina deverá ser substituído por um tambor de álcool.

Henry Ford, 1916

Wheels for the World: Henry Ford, His Company, and a Century of Progress

(Tradução retirada de GORDINHO, 2010) 


\section{Biocombustíveis: Etanol}

Biocombustíveis são combustíveis derivados de biomassa e, portanto alternativos aos de origem fóssil (IEA, 2015). Em outras palavras, são definidos como fontes de energia provenientes de processo biológico por fixação recente de carbono. Uma vez que o petróleo também é formado por fixação de carbono, mas em um período de eras, e na produção de biocombustíveis o carbono torna-se disponível em um intervalo de safras, é importante distinguir temporalmente os dois processos (VAN MARIS et al., 2006).

Adicionalmente, no uso dos biocombustíveis, o carbono presente na atmosfera é fixado pela planta, e volta à atmosfera quando queimado, não havendo introdução de mais carbono no sistema (PUPPÁN, 2002). Ao contrário, a queima de combustíveis fósseis reintroduz na atmosfera milhões de toneladas de carbono antes enterradas sob a superfície terrestre por milhares de anos (HÖÖK; TANG, 2013; VAN MARIS et al., 2006).

Se comparadas a outras fontes de energia renováveis atualmente disponíveis, como hidrelétrica, eólica e solar, a utilização de biomassa como matéria-prima para produção de biocombustíveis têm se destacado como principal alternativa aos combustíveis fósseis (NYLUND; AAKKO-SAKSA; SIPILÄ, 2008). Além de se basear em uma matéria prima amplamente disponível, biocombustíveis derivados de biomassa diminuem as emissões de gases responsáveis pelo efeito estufa, auxiliam no processo de sequestro de carbono, são sustentáveis e renováveis, além de economicamente reduzirem a dependência de combustíveis fósseis e suas decorrentes importações (DEMIRBAS, 2009; NIGAM; SINGH, 2011).

Sendo assim, biocombustíveis têm progressivamente ganhado espaço no mercado mundial (CLARK; LUQUE; MATHARU, 2012; MENON; RAO, 2012), tendo destaque o bioálcool (metanol, etanol, butanol), biodiesel, biogás, entre outros (DEMIRBAS, 2008; NIGAM; SINGH, 2011).

O etanol é um biocombustível derivado da fermentação de açúcares, extraídos, dentre outras fontes, de milho, beterraba e cana-de-açúcar (CLARK; LUQUE; MATHARU, 2012). Segundo a Agência de Proteção Ambiental dos EUA (EPA), o etanol proveniente da cana-deaçúcar tem capacidade de reduzir $61 \%$ da emissão de gases causadores de efeito estufa quando comparado à gasolina, enquanto o etanol de milho, produzido nos Estados Unidos, apresenta $21 \%$ de redução (GORDINHO, 2010).

Atualmente, o bioetanol representa aproximadamente $80 \%$ de todo o mercado de biocombustíveis, seguido pelo biodiesel (CLARK; LUQUE; MATHARU, 2012), e sua produção em 2013 foi estimada em aproximadamente 75 bilhões de litros (NIELSEN et al., 
2013). O Brasil é hoje o segundo maior produtor de etanol do mundo, com 27,6 bilhões de litros em 2013, atrás apenas dos Estados Unidos com 50,4 bilhões de litros (ANP, 2014).

Em veículos, este pode ser utilizado em sua forma pura ou combinada à gasolina (DEMIRBAS, 2008), e se destaca como uma das alternativas mais promissoras na redução da dependência de gasolina. O potencial do etanol como combustível não é visionado apenas para veículos terrestres, em 2014 foi lançado o VS-30, primeiro foguete nacional movido por uma combinação de etanol e oxigênio líquido, na base de Alcântara, MA (FAB, 2014).

\subsection{O cenário brasileiro}

O Brasil, apesar de ter grande potencial na indústria petroquímica e da recente descoberta de jazidas como o pré-sal, ainda é dependente da importação de petróleo para abastecer o mercado interno (EIA, 2014b). Ainda assim, desde 2008, o Brasil se destaca como o único país do mundo em que o consumo de gasolina é superado por um combustível alternativo, o etanol (JANK, 2009; UNICA, 2010).

No Brasil, a indústria sucroalcooleira é bem desenvolvida, e do período colonial até os anos 70 era principalmente voltada para produção de açúcar. Diante da crise do petróleo de 1973, o governo brasileiro criou em 1975 o Proálcool (Programa Nacional do Álcool). Com o programa, foram dados incentivos fiscais para o aumento do uso de etanol como combustível, além de tornar obrigatória a mistura do mesmo na gasolina, visando uma menor dependência da importação do combustível (MOREIRA; GOLDEMBERG, 1999).

Em 2012 no Brasil, o etanol já representava 70\% de todo o combustível utilizado em veículos, sendo boa parte representada pelos $20 \%$ de etanol adicionados à gasolina comum (CLARK; LUQUE; MATHARU, 2012). Em 2010, atingimos uma frota de 10 milhões de carros "flex", ou seja, capazes de utilizar tanto gasolina como etanol como combustível. Desde 2003, com o lançamento deste tipo de veículo, a utilização do etanol evitou o lançamento de mais de 100 milhões de toneladas de $\mathrm{CO}_{2}$ na atmosfera (UNICA, 2010). Contudo, segundo estimativas de crescimento da frota de veículos no Brasil, em 2020 será preciso dobrar a oferta de combustíveis para atender a demanda, assim como aumentar a produção de cana-de-açúcar de 555 milhões para 1,2 bilhões de toneladas por ano (UNICA, 2011a).

É necessário discutir a segurança energética brasileira, de forma que se reduza a dependência da importação de petróleo, e o mercado esteja menos sujeito a flutuações de preços. A demanda e as estimativas para o futuro impulsionam não apenas a indústria como 
também pesquisas biotecnológicas com o intuito de aumentar o rendimento e a produtividade do etanol.

\subsection{Produção de etanol: Primeira e segunda gerações}

Ainda no início do século XX, Albert Jan Kluyver já predizia a utilização de carboidratos e óleos presentes em plantas como matéria-prima para a indústria química:

Assim, a intensificação da agricultura, e seu desenvolvimento associado à indústria moderna, irá, no futuro, tornar-se cada vez mais comum. Isto significa que a indústria química será abastecida principalmente com alguns produtos agrícolas básicos, cujo valor deriva em grande parte de seu

conteúdo dos três principais grupos de substâncias, os carboidratos, óleos e proteínas. E assim, particularmente os hidrocarbonetos - os açúcares, amidos, e componentes da parede celular, - se tornarão proeminentes como matérias-primas.

Albert Jan Kluyver Albert Jan Kluyver, His Life and Work, 1959) (Tradução Livre)

Existe hoje a tendência de classificação dos biocombustíveis em primeira e segunda geração, baseada nas suas matérias primas (LENNARTSSON; ERLANDSSON; TAHERZADEH, 2014; MACHADO, 2013), tal como previsto por Kluyver. Combustíveis de primeira geração são aqueles derivados de açúcares e óleos, de fontes vegetais como cana-deaçúcar, milho, beterraba, sementes e oleaginosas, entre outras. De forma geral, da extração ao produto final, são combustíveis relativamente fáceis de obter (NIGAM; SINGH, 2011). No caso do etanol, pode-se utilizar qualquer matéria prima contendo carboidratos, seja ela sacarina (cana-de-açúcar, beterraba) ou amilácea (milho, trigo, arroz). Depois da extração dos açúcares fermentescíveis, a levedura Saccharomyces cerevisiae é responsável pela fermentação dos açúcares a etanol. A última etapa consiste na destilação do caldo, para purificação do etanol (MACHADO, 2013). As fontes de matéria prima para o etanol de primeira geração costumam entrar em conflito econômico e social, uma vez que também são usados na indústria alimentícia (CLARK; LUQUE; MATHARU, 2012; NIGAM; SINGH, 2011).

Os combustíveis de segunda geração são derivados de açúcares e óleos encontrados na biomassa lignocelulósica de plantas, e convertidos a combustíveis por meio de processos biológicos de esterificação (biodiesel) ou fermentação (etanol), ou ainda processos termoquímicos (pirólise) (TAYLOR, 2008). Geralmente, esses combustíveis são produzidos a 
partir de resíduos agroindustriais, como bagaço de cana, palha de milho e de trigo, ou de resíduos das indústrias madeireiras e de papel (CHERUBINI, 2010; SLUITER et al., 2010).

Uma vez que a produção de etanol de segunda geração utiliza os resíduos (principalmente) agroindustriais como fonte de matéria prima, o aumento da produção de etanol independe do aumento de áreas cultiváveis. Adicionalmente, não competem com o mercado de alimentos, como ocorre com o etanol de primeira geração(NIGAM; SINGH, 2011), e apresentam vantagens de distribuição, uma vez que esta matéria prima é comumente disponível para processamento no local de produção, quando comparada à difícil localização geográfica, acesso e transporte do petróleo (MENON; RAO, 2012).

O etanol brasileiro é produzido a partir de carboidratos presentes no caldo da cana-deaçúcar e classificado como combustível de primeira geração (DELLA-BIANCA; GOMBERT, 2013). Estima-se que a produção de etanol de segunda geração a partir de resíduos da produção de etanol de primeira geração (especialmente bagaço da cana) poderia aumentar em até $50 \%$ por unidade de área plantada (STAMBUK et al., 2008). Atualmente este bagaço não é desperdiçado. De cada tonelada de cana, cerca $288 \mathrm{~kg}$ são aproveitados na produção de energia elétrica de importância fundamental uma vez que a queima para produção de energia coincide com a seca dos reservatórios de usinas hidrelétricas (UNICA, 2011b). Nas safras de 2013/2014, foram produzidas 653.519 mil toneladas de cana de açúcar no Brasil, ou seja, aproximadamente 188213 mil toneladas de bagaço (UNICA, 2014).

A produção de etanol de segunda geração, a partir de resíduos lignocelulósicos é significativamente mais complexa do que a produção de primeira geração. Antes da fermentação, a biomassa lignocelulósica precisa passar por pré-tratamento, afim de reduzir a recalcitrância do material, e liberar os monômeros de açúcar para fermentação (ALMEIDA et al., 2011).

\section{Composicão da Biomassa}

A biomassa lignocelulósica é o principal componente estrutural de plantas e a maior fonte de matéria orgânica terrestre. Os principais componentes da lignocelulose são: celulose, hemicelulose e lignina, sendo que as porcentagens desta composição variam significativamente entre diferentes espécies de plantas (ALMEIDA et al., 2011). A celulose é um polímero homogêneo linear composto por monômeros de D-glicose (açúcares de seis carbonos). A hemicelulose é um polímero heterogêneo, sendo formado por pentoses como 
xilose e arabinose (açúcares de cinco carbonos) e hexoses (manose, glicose e galactose) (SAHA, 2004), conforme a Figura 1.

A utilização da biomassa lignocelulósica como matéria prima para produção de etanol esbarra em dois principais impasses relacionados à sua composição. Primeiramente, os monômeros de açúcar precisam ser liberados para fermentação, o que requer um prétratamento químico, físico, térmico e/ou enzimático da biomassa a fim de reduzir sua recalcitrância (PARACHIN; ALMEIDA, 2013).

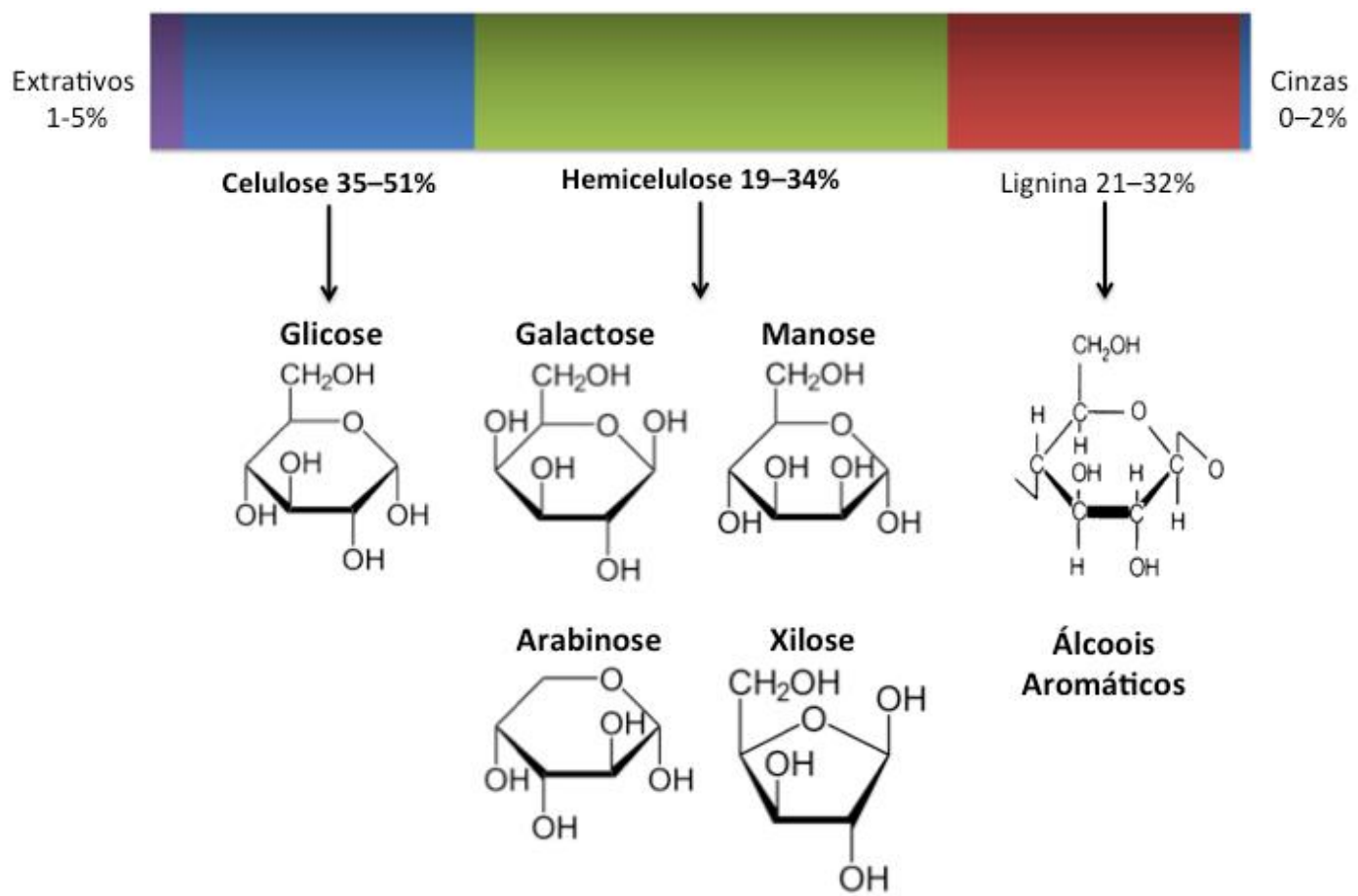

Figura 1: Composição percentual da biomassa lignocelulósica, com seus principais monômeros constituintes.

Adaptado de (ALMEIDA et al., 2007).

Em segundo lugar, nem todos os açúcares (hexoses) liberados são facilmente convertidos a etanol pelos microrganismos hoje empregados no processo industrial (GONG et al., 1983).

Como mostrado na Figura 1, a hemicelulose é composta por diferentes pentoses, como arabinose e, principalmente xilose (PARACHIN; ALMEIDA, 2013). A Tabela 1 mostra a composição percentual de algumas fontes de biomassa ricas em pentoses. 
Tabela 1: Composição percentual de resíduos lignocelulósicos agroindustriais.

\begin{tabular}{|c|c|c|c|c|c|c|c|}
\hline Material & Glucano & Manano & Galactana & Xilana & Arabinana & Lignana & Referência \\
\hline $\begin{array}{c}\text { Bagaço de cana- } \\
\text { de-açúcar }\end{array}$ & 41,4 & 3,4 & 1,3 & 22,5 & 1,3 & 23,6 & $\begin{array}{l}\text { (FERREIRA- } \\
\text { LEITÃO et al., } \\
\text { 2010) }\end{array}$ \\
\hline $\begin{array}{c}\text { Bagaço de cana- } \\
\text { de-açúcar }\end{array}$ & 43,3 & N.D & N.D & 24,3 & 2,0 & 22,8 & $\begin{array}{l}\text { (CARRASCO } \\
\text { et al., 2010) }\end{array}$ \\
\hline $\begin{array}{c}\text { Resíduo de milho } \\
\text { (Americana) }\end{array}$ & 36,1 & 1,8 & 2,5 & 21,4 & 3,5 & 17,2 & $\begin{array}{c}\text { (ÖHGREN et } \\
\text { al., 2007) }\end{array}$ \\
\hline $\begin{array}{c}\text { Resíduo de milho } \\
\text { (Italiana) }\end{array}$ & 36,8 & 0,3 & 2,9 & 22,2 & 5,5 & 21,2 & $\begin{array}{l}\text { Ohgren et al., } \\
2007\end{array}$ \\
\hline Palha de trigo & 41,2 & N.D & N.D & $26,1^{\mathrm{a}}$ & -- & 19,1 & $\begin{array}{l}\text { (RÉMOND et } \\
\text { al., 2010) }\end{array}$ \\
\hline Palha de cevada & 36,8 & N.D & 2,2 & 17,2 & 5,3 & 14,3 & $\begin{array}{c}\text { (LINDE; } \\
\text { GALBE; } \\
\text { ZACCHI, } \\
\text { 2007) }\end{array}$ \\
\hline Palha de arroz & 36,6 & N.D & N.D & 16,1 & N.D & 14,9 & $\begin{array}{c}\text { (HSU et al., } \\
\text { 2010) }\end{array}$ \\
\hline
\end{tabular}

N.D. não determinado; ${ }^{\mathrm{a}}=$ inclui arabinana

Adaptado de ALMEIDA, JOÃO R M et al., 2011.

A xilana é um polissacarídeo composto por monômeros de xilose. Esta, por sua vez, é uma pentose, e o segundo açúcar mais presente na lignocelulose, atrás apenas da glicose (HAHN-HÄGERDAL et al., 2006). No bagaço de cana, glicose e xilose podem representar respectivamente $62 \% \mathrm{~m} / \mathrm{m}$ e $33 \% \mathrm{~m} / \mathrm{m}$ do total de açúcares (FERREIRA-LEITÃO et al., 2010). Sua grande disponibilidade faz com que seja um importante alvo para desenvolvimento de estratégias de aproveitamento para produção de compostos de valor agregado, dentre eles o etanol (HAHN-HÄGERDAL et al., 2006).

Nesse contexto, um dos principais alvos de melhoramento do processo de utilização de biomassa para produção de etanol, é o desenvolvimento de linhagens de microrganismos capazes de fermentar hidrolisados contendo todos os diferentes açúcares (pentoses e hexoses) componentes da biomassa (PARACHIN; ALMEIDA, 2013). 


\subsection{Microrganismos e vias do catabolismo de xilose}

Microrganismos naturalmente capazes de fermentar xilose apresentam duas principais vias de catabolismo de xilose: a via da oxirredução e a via da isomerização (Figura 2).

A via da oxirredução da xilose é encontrada principalmente em leveduras e fungos filamentosos, e é composta de duas etapas: na primeira a xilose é reduzida a xilitol pela xilose redutase $(\mathrm{XR})$ e este, oxidado à xilulose pela xilitol desidrogenase (XDH - Figura 2: A). Na via da isomerização a xilose é isomerizada a xilulose pela xilose isomerase (XI - Figura 2: B) encontrada principalmente em procariotos, mas também presente em fungos filamentosos. Em ambas as vias a xilulose é fosforilada à xilulose-5-fosfato pela xiluloquinase (XK). A xilulose-5-fosfato é metabolizada pela via das pentoses fosfato até entrar na via glicolítica (KARHUMAA et al., 2007; KUYPER et al., 2003).

\section{Xilose}

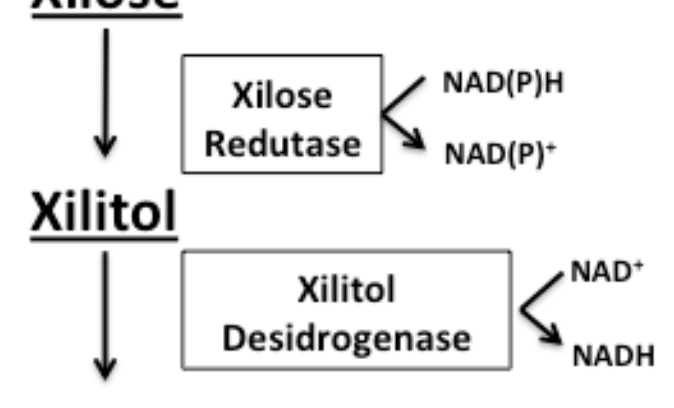

Xilulose

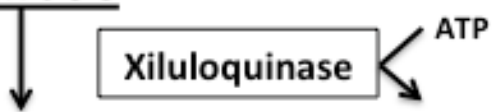

Xilulose -5P

A

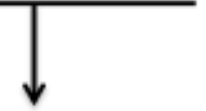

PPP $\underline{\text { Xilose }}$

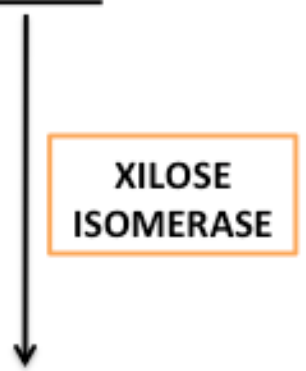

$\underline{\text { Xilulose }}$

Xiluloquinase $\underline{\text { Xilulose - 5P }}$

B

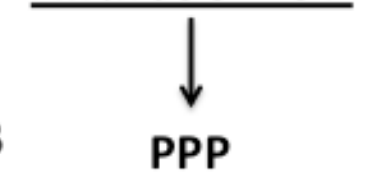

Figura 2: Vias metabólicas de catabolismo da xilose: $A=$ oxirredução $\mathrm{e} B=$ isomerização.

Adaptado de: KARHUMAA et al., 2007.

$\mathrm{Na}$ via de oxirredução, as duas enzimas envolvidas na conversão de xilose à xilulose, utilizam diferentes cofatores. Enquanto $\mathrm{XDH}$ utiliza unicamente $\mathrm{NAD}+, \mathrm{XR}$ utiliza preferencialmente NADPH (KOTTER; CIRIACY, 1993). Esta diferença gera um desbalanço de cofatores, levando ao excesso de formação de NADH (BRUINENBERG et al., 1983). 
Anaerobicamente, o excesso de NADH pode ser reoxidado, por meio da formação de xilitol (TOIVARI et al., 2004). O desbalanço de cofatores é um dos responsáveis pela redução da produtividade de etanol (KUYPER et al., 2004). Enquanto isso, a xilose isomerase depende da presença de cátions divalentes para atuar, frequentemente $\mathrm{Co}^{2+}, \mathrm{Mn}^{2+}$ ou $\mathrm{Mg}^{2+}$, dependendo da origem da enzima (BHOSALE; RAO; DESHPANDE, 1996).

As duas vias metabólicas são encontradas em diversos microrganismos entre archaeas, bactérias, fungos filamentosos e leveduras, capazes de fermentar xilose (HAHNHÄGERDAL et al., 2006). Pelo interesse na utilização de xilose como fonte de carbono para produção de etanol, a expressão heteróloga e a modificação destas vias em diferentes organismos têm sido amplamente exploradas (revisado por HAHN-HÄGERDAL et al., 2007).

Atualmente já foram construídas linhagens recombinantes de Zymomona mobilis, Klebsiella oxytoca e Escherichia coli entre outras, capazes de fermentar xilose a etanol (revisado por HAHN-HÄGERDAL et al., 2006). Entretanto, o organismo mais comumente utilizado em processos fermentativos industriais de produção de etanol é a levedura Saccharomyces cerevisiae (HAHN-HÄGERDAL et al., 2006).

\section{Saccharomyces cerevisiae}

Saccharomyces cerevisiae é uma levedura amplamente conhecida e utilizada pelos seres humanos. Desde a antiguidade é aplicada na panificação e na produção de vinhos e cervejas (NEVOIGT, 2008). Atualmente, é o eucarioto mais bem descrito e conhecido genética, fisiológica e metabolicamente (revisado por PAES; ALMEIDA, 2014). Seu genoma foi o primeiro de eucariotos a ser completamente sequenciado (GOFFEAU et al., 1996).

A quantidade de conhecimentos acumulado sobre este organismo, e disponível em bancos de dados, o torna uma plataforma atraente para melhoramentos genéticos e para engenharia metabólica (NEVOIGT, 2008; PAES; ALMEIDA, 2014; VAN MARIS et al., 2006). Atualmente é aplicado em indústrias para a produção dos mais diversos compostos, dentre eles propanodiol, farneseno, metil- ésteres, butanol, ácido succínico, lactato, glicerol, e claro, etanol (NEVOIGT, 2008; PAES; ALMEIDA, 2014).

Apesar de conhecermos o potencial de bactérias e outros microrganismos como possíveis produtores de etanol em escala industrial, a $S$. cerevisiae é hoje o microrganismo mais comumente utilizado na produção de biocombustíveis (VAN MARIS et al., 2007). Algumas características intrínsecas à $S$. cerevisiae são amplamente desejáveis, como sua 
capacidade de produzir etanol a altas taxas e com alto rendimento a partir de açúcares simples em diferentes condições de aeração (PAES; ALMEIDA, 2014).

A S. cerevisiae é a principal levedura que apresenta crescimento rápido em hexoses em condição de anaerobiose (KUYPER et al., 2003). Esta característica é fundamental para aplicação industrial da levedura, uma vez que a produção de etanol se dá em reatores, onde a aeração do sistema é considerada economicamente inviável (VAN MARIS et al., 2006). Além disso, S. cerevisiae apresenta alta tolerância a etanol, e é capaz de crescer em baixo pH, o que reduz problemas de contaminação do sistema por bactérias (NEVOIGT, 2008; PAES; ALMEIDA, 2014). Outro fator relevante para a produção de etanol de segunda geração, a $S$. cerevisiae também apresenta maior tolerância a compostos inibidores formados durante o processo de pré-tratamento da biomassa quando comparada a outros microrganismos (OLSSON; HAHN-HÄGERDAL, 1993).

Uma vez que a $S$. cerevisiae é a principal levedura utilizada para produção de etanol de primeira geração, ao tentar aplicar a mesma levedura para produção de etanol de segunda geração, esbarramos em restrições quanto à sua capacidade de fermentar todos os açúcares presentes na biomassa (GONG et al., 1983). Dentre os carboidratos encontrados na fração lignocelulósica, as linhagens selvagens de $S$. cerevisiae são capazes de fermentar outras hexoses além da glicose, como manose, frutose e galactose, por vias acopladas à via das pentoses fosfato. Entretanto estas linhagens são incapazes de fermentar ou assimilar pentoses (xilose e arabinose) (BATT et al., 1986; GONG et al., 1983), com exceção da D-xilulose, um isômero de xilose, que pode ser lentamente metabolizado na via das pentoses fosfato (UENG et al., 1981) ao ser fosforilada à D-xilulose-5-fosfato pela xiluloquinase (XK) (RODRIGUEZPEÑA et al., 1998).

\subsection{Engenharia metabólica de $S$. cerevisiae}

A engenharia metabólica, ou seja, a manipulação de fluxos metabólicos para produção de compostos desejados baseia-se em conhecimentos de genética, biologia molecular e bioquímica, como estratégia de melhoramento de organismos (NEVOIGT, 2008; VAN MARIS et al., 2007). Dentre as estratégias de engenharia metabólica de microrganismos podemos destacar quatro principais alvos frequentemente abordados no melhoramento de linhagens para o aproveitamento de xilose na produção de etanol de segunda geração: i) aumento de afinidade e especificidade dos transportadores para internalização de xilose (HAMACHER et al., 2002; SUBTIL; BOLES, 2012) e a cofermentação de açúcares (KIM et 
al., 2012); ii) expressão heteróloga de genes da via da isomerização e iii) da via de oxirredução da xilose (revisado por CAI; ZHANG; LI, 2012; SAUER, 2001; VAN MARIS et al., 2007) e iv) outros genes envolvidos com o metabolismo de xilose (revisado por VAN VLEET; JEFFRIES, 2009; NEVOIGT, 2008).

Outra estratégia que pode ser utilizada para melhoramento genético é a evolução adaptativa. Refletindo os princípios da seleção natural, a evolução adaptativa se aproveita da variação genética existente entre indivíduos para selecionar aqueles mais aptos diante de determinada pressão seletiva (SAUER, 2001). No caso de microrganismos utilizados em biotecnologia, a evolução adaptativa pode ser utilizada para obter linhagens mais tolerantes a compostos inibidores, linhagens com maior eficiência na produção de compostos desejáveis e na utilização de diferentes substratos (NEVOIGT, 2008; PAES; ALMEIDA, 2014; VAN MARIS et al., 2007).

Para que a $S$. cerevisiae seja capaz de utilizar outros carboidratos que não a glicose são necessários três requisitos principais. Primeiramente, a levedura deve ter transportadores funcionais para o carboidrato, caso contrário, este será fisicamente impossibilitado de participar de qualquer via metabólica. Em segundo lugar, é necessário que exista uma via ativa de catabolismo do carboidrato que se conecte com a via glicolítica para utilização deste carbono. Adicionalmente, é necessário que o balanço redox da célula seja mantido durante a utilização desses carboidratos (VAN MARIS et al., 2006).

A $S$. cerevisiae apresenta um conjunto de genes que possibilitariam a assimilação da xilose pela via de oxirredução (BATT et al., 1986; GONG et al., 1983). Na presença de xilose, genes essenciais para o metabolismo deste açúcar são induzidos, o que sugere que $S$. cerevisiae já foi capaz de crescer em xilose (TOIVARI et al., 2004). Entretanto, os baixos níveis de expressão destes genes, ocasionando a impossibilidade de converter eficientemente xilose a xilulose, inviabilizam o crescimento da levedura em xilose como única fonte de carbono (BATT et al., 1986; MATSUSHIKA et al., 2009).

É importante ressaltar que, o gene responsável pela enzima xiluloquinase, presente em ambas as vias de metabolismo de xilose, é endógeno da levedura $S$. cerevisiae (RODRIGUEZ-PEÑA et al., 1998), e responsável pela capacidade desta levedura de metabolizar xilulose (UENG et al., 1981) Figura 2).

Imagina-se que $S$. cerevisiae tenha evoluído de forma que a atividade das enzimas endógenas envolvidas no metabolismo de xilose seja tão baixa que impossibilitem o seu crescimento (TOIVARI et al., 2004; VAN MARIS et al., 2007). 
Duas principais soluções têm sido propostas para possibilitar o eficiente uso de xilose para produção de etanol pela $S$. cerevisiae. Primeiramente, selecionar ou engenheirar uma linhagem de S. cerevisiae capaz de utilizar o mesmo conjunto de cofatores tanto para XR quanto para $\mathrm{XDH}$, evitando acúmulo de xilitol. Outra alternativa seria a expressão heteróloga de uma XI sem a necessidade de enfrentar os problemas de desbalanço de cofatores da oxirredução, uma vez que essa enzima utiliza cátions divalentes como cofator (revisado por VAN MARIS et al., 2007; VAN VLEET; JEFFRIES, 2009).

\section{XI Piromyces}

Dado o potencial no desenvolvimento de linhagens de $S$. cerevisiae capazes de utilizar xilose para a produção de etanol, há também um grande interesse na identificação e caracterização de novos genes codificadores de XI. Diferentes XI foram identificadas em grupos de archaea (JOHNSEN; SCHÖNHEIT, 2004; JOHNSEN et al., 2009) e bacteria, animais (DING et al., 2009), além de algumas plantas. O banco de dados de proteínas Interpro (HUNTER et al., 2012) tem registradas atualmente mais de 3165 sequências da família das xiloses isomerases, sendo 5 de archaeas, 200 de eucariotos e mais de 2960 de bactérias, além de algumas sequências não classificadas (INTERPRO, 2015).

Durante décadas, não houve sucesso nas tentativas de expressão de xiloses isomerases de diferentes microrganismos em S. cerevisiae (revisado por VAN MARIS et al., 2007). No estudo de Sarthy de 1987, em que a xilose isomerase de E. coli foi expressa em S. cerevisiae, diferentes hipóteses foram propostas para explicar o fracasso da expressão da XI na levedura, tal como modificações pós-traducionais, mal dobramento de proteína, $\mathrm{pH}$ intracelular ou inespecificidade de cofatores. Entretanto, nenhum fator determinante foi encontrado (GÁRDONYI; HAHN-HÄGERDAL, 2003; MOES; PRETORIUS; ZYL, 1996; SARTHIY et al., 1987).

Em 1996 foi obtida uma linhagem de $S$. cerevisiae com atividade significativa de XI, a partir da expressão heteróloga do gene de Thermus thermophilus. Entretanto, a temperatura ótima para funcionamento da enzima, compatível com a origem termofílica do organismo, era inviável para S. cerevisiae (WALFRIDSSON et al., 1996).

Em 2003, KUYPER e colaboradores descreveram a expressão funcional de uma xilose isomerase eucariótica em $S$. cerevisiae. O fungo filamentoso anaeróbio obrigatório Piromyces $s p$., do qual se originou o gene utilizado, foi isolado das fezes do elefante indiano. No entanto, não foi identificada a atividade das enzimas da via de oxirredução. Os autores demonstraram 
que a via da xilose presente no fungo era de isomerização, e não oxirredução como comumente encontrada em eucariotos. Após identificar o possível gene codificador para XI, e expressá-lo em linhagem laboratorial de S. cerevisiae, observou-se o crescimento da levedura em meio mínimo com xilose com taxa de crescimento de $0,005 \mathrm{~h}^{-1}$. A expressão de XI de Piromyces em Saccharomyces cerevisiae, apesar de não ser a única funcional descrita, impulsionou estudos na área de expressão da via de XI para fermentação anaeróbia de xilose para produção de etanol.

Neste trabalho, os genes XylA de Piromyces sp. e XKS1 endógeno de $S$. cerevisiae foram clonados em vetores epissomais sob controle dos promotores constitutivos fortes GPD (BITTER; EGAN, 1984) e TEF (COTTRELLE et al., 1985) de S. cerevisiae, respectivamente. Os vetores epissomais permitem um maior nível de expressão dos genes devido às múltiplas cópias do plasmídeo que podem ser mantidas no citoplasma. O alto nível de expressão dos genes é desejável para possibilitar o crescimento dos transformantes em xilose.

O desenvolvimento de linhagens laboratoriais eficientes na conversão anaeróbia de xilose a etanol é fundamental para a melhor compreensão dos mecanismos envolvidos no processo, e aplicação destes conhecimentos em leveduras industriais. Adicionalmente, considerando a diversidade microbiológica, a identificação e caracterização de novas XI podem revelar enzimas ainda desconhecidas, e com potencial para aplicação biotecnológica na produção de etanol. 


\section{OBJETIVOS}

\section{Objetivo geral}

- Construção de linhagens recombinantes de $S$. cerevisiae para aproveitamento de xilose na produção de etanol.

\section{Objetivos específicos}

- Construção de linhagens transformantes capazes de utilizar xilose através da via de isomerização;

- Evolução adaptativa das linhagens transformantes para utilização de xilose como única fonte de carbono;

- Caracterização fisiológica das linhagens recombinantes geradas

- Desenvolvimento de linhagens para seleção de novas XI. 


\section{MATERIAIS E MÉTODOS}

\section{Microrganismos}

Linhagens de bactérias e leveduras congênicas utilizadas no trabalho (Tabela 2).

Tabela 2: Linhagens de microrganismos utilizados neste trabalho.

\begin{tabular}{|c|c|c|}
\hline Bactérias & & \\
\hline Linhagens & Genótipo & Referência \\
\hline E. coli XL 10 Gold & 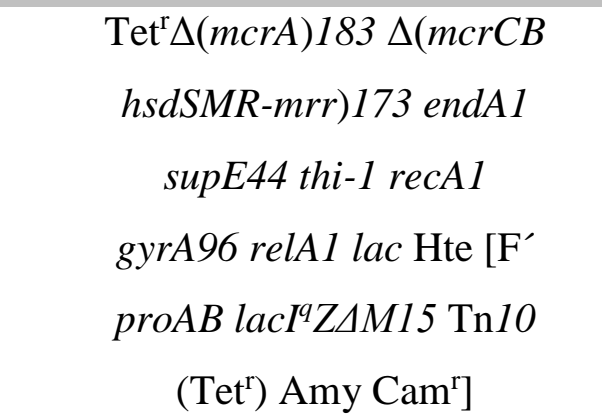 & $\begin{array}{c}\text { Strategene } \\
\text { (ROTHEN et al., 1998) }\end{array}$ \\
\hline \multicolumn{3}{|l|}{ Leveduras } \\
\hline Linhagens & Genótipo & Referência \\
\hline $\begin{array}{l}\text { S. cerevisiae } \\
\text { CEN.PK 113.3C }\end{array}$ & $M A T a, \operatorname{trp} 1-289, M A L 2-8 C, S U C 2$ & $\begin{array}{c}\text { (ENTIAN; KOTTER, } \\
\text { 2007) }\end{array}$ \\
\hline $\begin{array}{l}\text { S. cerevisiae } \\
\text { CEN.PK 113.14A }\end{array}$ & $\begin{array}{c}\text { MATa, ura3-52, trp1-289, MAL2- } \\
8 C, \text { SUC2 }\end{array}$ & $\begin{array}{c}\text { (ENTIAN; KOTTER, } \\
\text { 2007) }\end{array}$ \\
\hline
\end{tabular}

\section{Genes}

Genes da via de catabolismo de xilose utilizados na construção de cassete para expressão em S. cerevisiae.

XylA: gene codificador para xilose isomerase de Piromyces $s p$.

XKS1: gene endógeno de $S$. cerevisiae para expressão de xiluloquinase.

\section{Oligonucleotídeos}

Conjunto de oligonucleotídeos utilizados neste trabalho (Tabela 3). 
Tabela 3: Oligonucleotídeos utilizados na construção de cassetes de expressão.

\begin{tabular}{|c|c|c|c|c|}
\hline & $\begin{array}{l}\text { Oligonucleot } \\
\text { ídeo }\end{array}$ & $\begin{array}{l}\text { Sequência (5' } \\
\left.\rightarrow 3^{\prime}\right)\end{array}$ & Descrição & Referência \\
\hline 1 & $\begin{array}{l}\text { BamHI-GPD } \\
-\mathrm{F}\end{array}$ & $\begin{array}{l}\text { CG GGATCC } \\
\text { agtttatcattatcaa } \\
\text { tactgc }\end{array}$ & $\begin{array}{l}\text { Amplificação de cassete de } \\
\text { expressão a partir do } \\
\text { promotor GPD inserindo } \\
\text { sítio de restrição BamHI na } \\
\text { região 5' do gene. }\end{array}$ & $\begin{array}{l}\text { (MUMBERG; } \\
\text { MULIER; } \\
\text { FUNK, 1994) }\end{array}$ \\
\hline 2 & $\begin{array}{l}\text { BamHI-Cyc- } \\
\text { R }\end{array}$ & $\begin{array}{l}\text { CG GGATCC } \\
\text { ggccgcaaattaaa } \\
\text { gc }\end{array}$ & $\begin{array}{l}\text { Amplificação de cassete de } \\
\text { expressão a partir de } \\
\text { terminador Cyc inserindo } \\
\text { sítio de restrição BamHI na } \\
\text { região 5' do gene. }\end{array}$ & $\begin{array}{l}\text { (MUMBERG; } \\
\text { MULIER; } \\
\text { FUNK, 1994) }\end{array}$ \\
\hline 3 & $\begin{array}{l}\text { BamHI-TEF- } \\
\text { F }\end{array}$ & $\begin{array}{l}\text { CG GGATCC } \\
\text { catagcttcaaaatg } \\
\text { tttct }\end{array}$ & $\begin{array}{l}\text { Amplificação de cassete de } \\
\text { expressão a partir de } \\
\text { promotor TEF }\end{array}$ & $\begin{array}{l}\text { (MUMBERG; } \\
\text { MULIER; } \\
\text { FUNK, 1994) }\end{array}$ \\
\hline 7 & $\begin{array}{l}\text { SpeI }-X y l A- \\
\text { F }\end{array}$ & $\begin{array}{l}\text { GTGGCCCA } \\
\text { GCCGGC- } \\
\text { CAAAATGG } \\
\text { CTAAGGAA } \\
\text { TATTTC }\end{array}$ & $\begin{array}{l}\text { Amplificação do gene para } \\
\text { XIPiro (XylA) inserindo sítio } \\
\text { de restrição SpeI na região } 5 \\
\text { do gene. }\end{array}$ & $\begin{array}{l}\text { (KUYPER et } \\
\text { al., 2003) }\end{array}$ \\
\hline 8 & Sal $-X y l A-\mathrm{R}$ & $\begin{array}{l}\text { AATC- } \\
\text { TAGATATTG } \\
\text { GTACATGGC } \\
\text { AACAATAG }\end{array}$ & $\begin{array}{l}\text { Amplificação do gene para } \\
\text { XIPiro (XylA) inserindo sítio } \\
\text { de restrição SalI na região 3' } \\
\text { do gene. }\end{array}$ & $\begin{array}{l}\text { (KUYPER et } \\
\text { al., 2003) }\end{array}$ \\
\hline 9 & $\begin{array}{l}\text { SpeI 5'- } \\
\text { XKS1-F }\end{array}$ & $\begin{array}{l}\text { gACTAGTatgt } \\
\text { tgtgttcagtaattca } \\
\text { g }\end{array}$ & $\begin{array}{l}\text { Amplificação do gene para } \\
\text { XK }(X K S 1) \text { inserindo sítio de } \\
\text { restrição SpeI na região } 5 \text { 'do } \\
\text { gene. }\end{array}$ & $\begin{array}{l}\text { (KUYPER et } \\
\text { al., 2005) }\end{array}$ \\
\hline 10 & $\begin{array}{l}3^{\prime} \mathrm{XKS} 1- \\
\text { SalI-R }\end{array}$ & $\begin{array}{l}\text { tgcaGTCGAC } \\
\text { attttagatgagagt } \\
\text { cttttcc }\end{array}$ & $\begin{array}{l}\text { Amplificação do gene para } \\
\text { XK }(X K S 1) \text { inserindo sítio de } \\
\text { restrição SalI na região 3' do } \\
\text { gene. }\end{array}$ & $\begin{array}{l}\text { (KUYPER et } \\
\text { al., 2005) }\end{array}$ \\
\hline 11 & $\mathrm{p} 423-\mathrm{F}$ & $\begin{array}{l}\text { caccagaacttagtt } \\
\text { tcgac }\end{array}$ & $\begin{array}{l}\text { Amplificação de porção da } \\
\text { região 3' do promotor GPD }\end{array}$ & Este trabalho \\
\hline 12 & P423-R & $\begin{array}{l}\text { gcgtgaatgtaagc } \\
\text { gtgac }\end{array}$ & $\begin{array}{l}\text { Amplificação de porção da } \\
\text { região 5' do terminador TEF }\end{array}$ & Este trabalho \\
\hline
\end{tabular}




\section{Vetores}

Vetores utilizados no trabalho (Tabela 4).

Tabela 4: Vetores em E. coli e $S$. cerevisiae.

\begin{tabular}{|c|c|c|}
\hline Plasmídeo & Descrição & Referência \\
\hline p424 & $\mathrm{P}_{\mathrm{GPD}} \mathrm{T}_{\mathrm{Cyc}}, \mathrm{ampR}, \mathrm{TRP} 1,2 \mu$ origin & $\begin{array}{l}\text { (MUMBERG; } \\
\text { FUNK, 1994) }\end{array}$ \\
\hline P426 & $\mathrm{P}_{\mathrm{TEF}} \mathrm{T}_{\mathrm{Cyc}}, \mathrm{ampR}, \mathrm{URA} 3,2 \mu$ origin & $\begin{array}{l}\text { (MUMBERG; } \\
\text { FUNK, 1994) }\end{array}$ \\
\hline pRH218 & $\begin{array}{l}\text { pBluescript II SK+, URA3, } 2 \mu \text { origin } \\
\text { + PHXT7-Piromyces XI-THXT7 }\end{array}$ & (HECTOR et al., 2011a) \\
\hline pRH195 & $\begin{array}{l}\text { pBluescript II SK?, TRP1, CEN6, } \\
\text { ARSH4 ? PHXT7-XKS1-THXT7 }\end{array}$ & (HECTOR et al., 2011b) \\
\hline
\end{tabular}

\section{Enzimas}

\subsection{Enzimas de restrição}

As enzimas de restrição utilizadas foram Fast Digest Restriction Enzyme (Thermo Scientific), seguindo recomendações do fabricante.

\subsection{Taq Polimerase}

Enzima Taq DNA Polymerase (Thermo Scientific) utilizada nas reações de PCR, conforme recomendações do fabricante.

\subsection{Pfu Polimerase}

Enzima Pfu Polimerase (Thermo Scientific) utilizada nas reações de PCR, conforme recomendações do fabricante.

\subsection{T4 DNA Ligase}

Enzima T4 DNA Ligase (Thermo Scientific) utilizada nas ligações de fragmentos de DNA, conforme recomendações descritas pelo fabricante.

\subsection{RNAse A}

Enzima RNAse A, DNAse and protease-free (10 mg/mL) (Thermo Scientific) utilizada conforme recomendações descritas pelo fabricante. 


\section{Marcador molecular}

Em géis de agarose foi utilizado o marcador molecular GeneRuler DNA Ladder Mix $0,5 \mu \mathrm{g} / \mu \mathrm{L}$ (Thermo Scientific) como referência de peso molecular e concentração de DNA.

\section{Solucões}

As soluções utilizadas são descritas abaixo.

\subsection{Antibióticos}

\section{Ampicilina}

Ampicilina dissolvida em água Milli-Q (concentração final $50 \mathrm{mg} / \mathrm{mL}$ ) e esterilizada por filtração com membrana Millipore 0,22 $\mu \mathrm{m}$. Concentração final de uso: $50 \mu \mathrm{g} / \mathrm{mL}$.

\subsection{Análise em gel de agarose}

\section{Tampão SB}

$\mathrm{NaOH}$

$0,8 \%(\mathrm{p} / \mathrm{v})$

Ácido Bórico

$4,5 \%(\mathrm{p} / \mathrm{v})$

pH ajustado com ácido bórico até atingir 8,0.

\section{Brometo de etídio (EtBr)}

Brometo de etídio foi diluído em água Milli-Q (concentração final 62,5 $\mu \mathrm{g} / \mathrm{mL}$ ).

Concentração final de uso: $5 \mu \mathrm{g} / \mathrm{mL}$

\subsection{Solução de aminoácidos}

\section{Triptofano (Trp)}

L-triptofano

$$
1,0 \%(\mathrm{p} / \mathrm{v})
$$

Dissolvido em água Milli-Q, esterilizado por filtração com membrana Millipore 0,22 $\mu \mathrm{m}$.

\subsection{Solução para Análise em HPLC (Cromatografia líquida de alta performance) Ácido Sulfúrico $\left(\mathrm{H}_{2} \mathrm{SO}_{4}\right) 5 \mathrm{mM}$

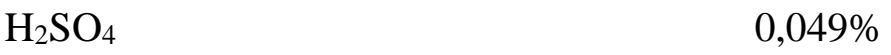

Completar com água Milli-Q. 


\subsection{Solução de Sais (10X)}

Sulfato de amônio $\left(\left(\mathrm{NH}_{4}\right)_{2} \mathrm{SO}_{4}\right)$ $50 \mathrm{~g} / \mathrm{L}$

Sulfato de magnésio $\left(\mathrm{MgSO}_{4}-7 \mathrm{H}_{2} \mathrm{O}\right)$

Fosfato de potássio monobásico $\left(\mathrm{KH}_{2} \mathrm{PO}_{4}\right)$

\subsection{Solução de Vitaminas (1000X)}

Dissolver 0,005g de biotina em $1 \mathrm{ml}$ de $\mathrm{NaOH}$ 0,1M (hidróxido de sódio) e adicionar 80mL de $\mathrm{H}_{2} \mathrm{O}$. Ajustar $\mathrm{pH}$ para 6,5 com $\mathrm{HCl} 1 \mathrm{M} / \mathrm{NaOH} 1 \mathrm{M}$. Dissolver as seguintes vitaminas nas soluções de biotina, uma de cada vez. O pH é ajustado para 6,5 após cada adição:

\begin{tabular}{ll} 
Pantotenato de cálcio $\left(\left(\mathrm{C}_{9} \mathrm{H}_{16} \mathrm{NO}_{5}\right)_{2} \mathrm{Ca}\right)$ & $0,1 \mathrm{~g}$ \\
Niacina $\left(\mathrm{C}_{6} \mathrm{H}_{5} \mathrm{NO}_{2}\right)$ & $0,1 \mathrm{~g}$ \\
Inositol $\left(\mathrm{C}_{6} \mathrm{H}_{12} \mathrm{O}_{6}\right)$ & $2,5 \mathrm{~g}$ \\
Cloridrato de tiamina $\left(\mathrm{C}_{12} \mathrm{H}_{17} \mathrm{ClN}_{4} \mathrm{O}_{5}\right)$ & \multicolumn{2}{c}{$0,1 \mathrm{~g}$} \\
Cloridrato de piridoxina $\left(\mathrm{C}_{8} \mathrm{H}_{11} \mathrm{NO}_{3}\right)$ & $0,1 \mathrm{~g}$ \\
Ácido papa-aminobenzóico $\left(\mathrm{C}_{7} \mathrm{H}_{7} \mathrm{NO}_{2}\right)$ & $0,02 \mathrm{~g}$ \\
Riboflavina $\left(\mathrm{C}_{17} \mathrm{H}_{20} \mathrm{~N}_{4} \mathrm{O}_{6}\right)$ & $0,02 \mathrm{~g}$ \\
Ácido fólico $\left(\mathrm{C}_{19} \mathrm{H}_{19} \mathrm{~N}_{7} \mathrm{O}_{6}\right)$ & $0,0002 \mathrm{~g}$
\end{tabular}

Ajustar volume para $100 \mathrm{~mL}$ com água e $\mathrm{pH}=6,5$. Esterilizar por filtração com membrana Millipore 0,22 $\mu \mathrm{m}$, e dividir o volume em tubos de $50 \mathrm{~mL}$. Armazenar na geladeira.

\subsection{Solução de Elementos Traço (1000x)}

Dissolver 1,5 g de EDTA dissódico (etilenodiamino tetracético) em 50mL de $\mathrm{H}_{2} \mathrm{O}$. Adicionar 0,45 g de sulfato de zinco heptahidratado $\left(\mathrm{ZnSO}_{4}-7 \mathrm{H}_{2} \mathrm{O}\right)$. Ajustar $\mathrm{pH}$ para 6,0 e adicionar os seguinte componentes, ajustando pH após cada adição:

$\begin{array}{ll}\text { Cloreto de manganês dihidratado }\left(\mathrm{MnCl}_{2}-2 \mathrm{H}_{2} \mathrm{O}\right) & 0,1 \mathrm{~g} \\ \text { Cloreto de cobalto hexahidratado }\left(\mathrm{CoCl}_{2}-6 \mathrm{H}_{2} \mathrm{O}\right) & 0,03 \mathrm{~g} \\ \text { Sulfato de cobre pentahidratado }\left(\mathrm{CuSo}_{4}-5 \mathrm{H}_{2} \mathrm{O}\right) & 0,03 \mathrm{~g} \\ \text { Molibidato de sódio hidratado }\left(\mathrm{Na}_{2} \mathrm{MoO}_{4}-\mathrm{H}_{2} \mathrm{O}\right) & 0,04 \mathrm{~g} \\ \text { Cloreto de cálcio dihidratado }\left(\mathrm{CaCl}_{2}-2 \mathrm{H}_{2} \mathrm{O}\right) & 0,45 \mathrm{~g} \\ \text { Sulfato de ferro heptahidratado }\left(\mathrm{FeSO}_{4}-7 \mathrm{H}_{2} \mathrm{O}\right) & 0,3 \mathrm{~g} \\ \text { Ácido bórico }\left(\mathrm{H}_{3} \mathrm{BO}_{3}\right) & 0,1 \mathrm{~g} \\ \text { Iodeto de potássio }(\mathrm{KI}) & 0,01 \mathrm{~g}\end{array}$


Ajustar pH para 4,0 e o volume para 100mL. Com filtro estéril (Millipore 0,22 $\mu \mathrm{m}$ ), dividir em tubos de 50mL e armazenar a solução na geladeira.

\subsection{Ergosterol/Tween 80}

Dissolver 1,6 g de ergosterol em $64 \mathrm{~mL}$ de etanol puro em banho-maria à $70^{\circ} \mathrm{C}$, adicionar $67,2 \mathrm{~g}$ de Tween 80 e ajustar o volume para $200 \mathrm{~mL}$ com etanol puro. Esterilizar por filtração com membrana Millipore 0,22 $\mu \mathrm{m}$.

\section{Meios de cultura}

Os meios de cultura utilizados são descritos abaixo. Todos foram esterilizados por calor úmido a $120^{\circ} \mathrm{C}$ por 15 min em autoclave.

\subsection{Meios de cultura para bactéria}

\section{LB (Luria-Bertani)}

Peptona

$1 \%(\mathrm{p} / \mathrm{v})$

Extrato de levedura

$$
0,5 \%(\mathrm{p} / \mathrm{v})
$$

$\mathrm{NaCl}$ $1 \%(\mathrm{p} / \mathrm{v})$

pH ajustado para 7,2 com solução de $\mathrm{NaOH}$

Esterilizado por autoclave.

\section{Meio LB-Ágar}

Meio LB adicionado de ágar 2\% (p/v) antes de ser autoclavado.

\subsection{Meios de cultura para levedura}

\section{Meio YPD (Meio extrato de levedura peptona glicose)}

Extrato de levedura

Peptona

Glicose

Esterilizado por autoclave.

$$
\begin{aligned}
& 1 \%(\mathrm{p} / \mathrm{v}) \\
& 2 \%(\mathrm{p} / \mathrm{v}) \\
& 2 \%(\mathrm{p} / \mathrm{v})
\end{aligned}
$$




\section{Meio YPD-ágar}

Meio YPD adicionado de ágar 2\% (p/v) antes de ser autoclavado.

\section{Meio YPX (Meio extrato de levedura peptona xilose)}

Extrato de levedura $1 \%(\mathrm{p} / \mathrm{v})$

Peptona $2 \%(\mathrm{p} / \mathrm{v})$

Xilose $2 \%(\mathrm{p} / \mathrm{v})$

Esterilizado por autoclave.

\section{Meio YPX-ágar}

Meio YPX adicionado de ágar 2\% (p/v) antes de ser autoclavado.

\section{Meio YNB 10X (estoque)}

YNB: meio sintético

YNB

$$
1,7 \%(\mathrm{p} / \mathrm{v})
$$

Sulfato de amônia $5 \%(\mathrm{p} / \mathrm{v})$

Meio YG20 (YNB 1X + Glicose 20g/L)

YNB 10X $10 \%$

Glicose $2 \%(\mathrm{p} / \mathrm{v})$

\section{Meio YG20 ágar}

Meio YG20 adicionado de ágar 2\% (p/v) antes de ser autoclavado.

Meio YX40 (YNB 2X + Xilose 40g/L)

YNB 10X

$20 \%$

Xilose $4 \%(\mathrm{p} / \mathrm{v})$

\section{Meio YX40 ágar}

Meio YX40 adicionado de ágar 2\% (p/v) antes de ser autoclavado.

Meio YG20/YX40 (YNB 2X + Glicose 20g/L + Xilose 40g/L)

YNB 10X

Glicose $2 \%(\mathrm{p} / \mathrm{v})$ 
Xilose

$4 \%(\mathrm{p} / \mathrm{v})$

\section{Meio YG20/X40 ágar}

Meio YG20/X40 adicionado de ágar 2\% (p/v) antes de ser autoclavado.

$\begin{array}{lc}\text { Meio mínimo para fermentação em biorreator } \\ \text { Solução de Sais } & 25 \% \\ \text { Solução de Vitaminas } & 0,25 \% \\ \text { Solução de Elementos Traço } & 0,25 \% \\ \text { Ergosterol/Tween } 80 ® & 0,125 \% \\ \text { Glicose } & 20 \mathrm{~g} / \mathrm{L} \\ \text { Xilose } & 40 \mathrm{~g} / \mathrm{L}\end{array}$

\section{Protocolos}

\subsection{PCR (Polimerase Chain Reaction)}

As PCRs foram feitas de acordo com as especificações do fabricante da enzima (Thermo Scientific).

Cada reação de PCR com volume final de $50 \mu \mathrm{L}$ continha: Tampão de PCR 10X (Thermo Scientific) concentração final $1 \mathrm{X}, \mathrm{MgCl}_{2} 50 \mathrm{mM}$ (Thermo Scientific) concentração final 1,5 mM, dNTPs (Thermo Scientific) concentração final 0,2 mM, oligonucleotídeos (Tabela 3) concentração final $0,2 \mu \mathrm{M}$, enzima Taq $5 \mathrm{U} / \mu \mathrm{L}$ (Thermo Scientific) concentração final 1,25 U/ml, 1 a $3 \mathrm{uL}$ de DNA molde, que quando purificado, variou de concentrações entre 10 e 100 ng por reação, e água Milli-Q completando ao volume final da reação.

No caso da PCR de colônia de bactéria para confirmação de transformante, a quantidade equivalente à uma colônia de células foi diluída em $10 \mu \mathrm{L}$ de água destilada estéril, em tubos de $0,2 \mathrm{~mL}$. Para a cada reação foram utilizados, $2 \mu \mathrm{L}$ das células em suspensão como DNA molde.

No caso da PCR de colônia de levedura para confirmação dos transformantes, a quantidade equivalente à uma colônia de células foi misturada a $10 \mu \mathrm{L}$ de água destilada estéril, ou $10 \mu \mathrm{L}$ da cultura líquida foi centrifugada e ressuspendida em $100 \mu \mathrm{L}$ de água destilada estéril, em microtubos de $1,5 \mathrm{~mL}$. O conteúdo celular foi aquecido a $94{ }^{\circ} \mathrm{C}$ por seis 
minutos e em seguida resfriado em freezer $-80{ }^{\circ} \mathrm{C}$ por 15 minutos. Essa variação de temperatura tem por objetivo lisar as células, liberando seu conteúdo celular, incluindo DNA. Posteriormente os tubos foram centrifugados à $10.000 \mathrm{~g}$ por 3 minutos para precipitação de componentes celulares, e do sobrenadante, $2 \mu \mathrm{L}$ foram utilizados como molde para reações de PCR.

As PCRs foram realizadas em termociclador Veriti ${ }^{\mathrm{TM}}$ Thermal Cycler (Applied Biosystems) com o seguindo o programa: " 1 a fase - desnaturação inicial: $95{ }^{\circ} \mathrm{C}$ por 5 minutos, $2^{\mathrm{a}}$ fase - desnaturação: $95^{\circ} \mathrm{C}$ por 30 segundos, $3^{\mathrm{a}}$ fase - anelamento: Tm do oligonucleotídeo por 30 segundos, $4^{\mathrm{a}}$ fase - extensão: $72^{\circ} \mathrm{C}$ por 4 minutos, $5^{\mathrm{a}}$ fase - extensão final: $72{ }^{\circ} \mathrm{C}$ por 10 minutos. As etapas 2, 3 e 4 foram repetidas por trinta ciclos, antes da $5^{\text {a }}$ etapa.

A verificação do funcionamento das PCRs foi feito pela aplicação dos produtos finais da reação e análise por eletroforese em géis de agarose.

\subsection{Eletroforese em gel de agarose}

Verificações de integridade e quantificação de DNA, funcionamento de PCR, e extração de DNA foram feitos por eletroforese em gel de agarose $1 \%$ contendo brometo de etídio. As corridas foram feitas em cubas de eletroforese Thermo Scientific, contendo tampão SB 1X. Os resultados dos géis foram visualizados e fotografados em foto documentador modelo L-PIX Chemi com auxílio do programa L-Pix Image.

\subsection{Restrições}

As reações de restrição foram feitas com as enzimas de restrição Thermo Scientific utilizando $0,2 \mu \mathrm{g}$ a $5 \mu \mathrm{g}$ de DNA. As reações foram feitas em termociclador Veriti ${ }^{\mathrm{TM}}$ Thermal Cycler (Applied Biosystems) seguindo tempo definido pelo fabricante para cada enzima.

\subsection{Ligação}

As reações de ligação inserto com vetor foram feitas com proporção 3:1 (inserto:vetor), utilizando a enzima T4 DNA Ligase (Thermo Scientific) segundo as especificações do fabricante. 


\subsection{Purificação de fragmento de DNA em gel de agarose}

As purificações de DNA das bandas de gel de agarose foram feitas com o Kit Nucleospin Gel and PCR cleanup (Macherey-Nagel) segundo as especificações do fabricante.

\subsection{Purificação de plasmídeos e PCR}

As purificações de DNA de PCR e também de plasmídeos extraídos por midipreparação caseira foram feitos com o kit GeneJET PCR purification kit da Thermo Scientific, segundo especificações do fabricante.

\subsection{Preparo de células eletrocompetentes}

O preparo de células eletrocompetentes foi feita de acordo com protocolo "HighEfficiency Transformation by Electroporation" encontrado no manual do eletroporador da Bio-Rad "MicroPulser" ${ }^{\mathrm{TM}}$ Electroporation Apparatus Operating Instructions and Applications Guide," 2000.

\subsection{Preparo e transformação de Levedura}

O preparo e transformação de levedura (S. cerevisiae) para choque térmico foi feito segundo protocolo "Large-scale high-efficiency yeast transformation using the LiAc/SS carrier DNA/PEG method' descrito por GIETZ; SCHIESTL (2007).

\subsection{Transformação de Bactéria por eletroporação (E. coli)}

A transformação por eletroporação foi realizada em Electroporator 2510 (Eppendorf). Foram adicionados entre 1 e $5 \mu \mathrm{L}$ do plasmídeo à $50 \mu \mathrm{L}$ de células eletrocompetentes retiradas do freezer $-80{ }^{\circ} \mathrm{C}$ e descongeladas no gelo. As células com o DNA foram transferidos para cuveta de eletroporação de 0,1 cm Gene Pulser Cuvette (Bio-Rad) estéril e previamente resfriada. No eletroporador, a cuveta com células foi submetida à um pulso de $1,8 \mathrm{kV}$. Após o pulso foi imediatamente adicionado $1 \mathrm{~mL}$ de meio LB para recuperação das células, e este, transferido para tubo $(1,5 \mathrm{~mL})$, e incubado à $37{ }^{\circ} \mathrm{C}$ por uma hora. Alíquotas de $100 \mu \mathrm{L}, 200 \mu \mathrm{L}$ e todo o restante do meio foram plaqueados em meio LB sólido contendo o antibiótico adequado. As placas foram incubadas em estufa a $37^{\circ} \mathrm{C}$ durante a noite.

\subsection{Extração de DNA plasmidial por lise alcalina (Midipreparação de Bactéria)}

A extração de DNA plasmidial por lise alcalina de E. coli foi feita segundo protocolo descrito no Protocol 2: Preparation of plasmid DNA by alkaline lysis with SDS: Midipreparation, encontrado em Molecular Cloning - A Laboratory Manual ("Molecular 
Cloning - Sambrook \& Russel”, 2001). Os plasmídeos foram purificados com RNAse A (concentração final $2 \mu \mathrm{g} / \mu \mathrm{L}$ ).

\subsection{Extração de DNA plasmidial (Minipreparação de Levedura)}

A extração de DNA plasmidial de levedura foi feito segundo o protocolo adaptado " $A$ simple and highly eficiente procedure for rescuing autonomous plasmids from yeast" descrito em ROBZYK; KASSIR, (1992).

O cultivo da cultura de levedura foi feito em $5 \mathrm{~mL}$ de meio, e nas seguintes etapas, foi seguido protocolo conforme descrito pelos autores supracitados. Na etapa de precipitação, após adicionar o etanol gelado, o DNA foi incubado 30 minutos a $20{ }^{\circ} \mathrm{C}$ antes de ser centrifugado, lavado e ressuspendido.

\section{Curva de crescimento em tubo de ensaio}

O teste de crescimento de colônias isoladas das linhagens de transformantes foi feito por fermentação única em meio mínimo com xilose liquido, em tubos de ensaio de 50mL.

As colônias foram plaqueadas em meio YX40 ágar a partir de estoque de glicerol e incubadas em estufa bacteriológica a $30{ }^{\circ} \mathrm{C}$ por 144 horas. Colônias aleatórias foram escolhidas e replicadas em placa de meio YG20 ágar, e crescidas durante a noite em estufa a $30{ }^{\circ} \mathrm{C}$. A partir das placas, foi feito o mesmo procedimento de tratamento de inóculo utilizado nas fermentações em erlenmeyer. As seis colônias de cada uma das linhagens de transformante foram inoculadas em meio YG20 e crescidas por 48 horas a $28{ }^{\circ} \mathrm{C}$ em shaker rotativo à 180 rpm (MAX Q8000 Thermo Scientific). Após o crescimento, as células foram centrifugadas (1200 g por 5 minutos), o sobrenadante de meio de glicose descartado, e as células ressuspendidas em YX40, incubado a $28^{\circ} \mathrm{C}$ por a $180 \mathrm{rpm}$ em shaker rotativo.

A fermentação foi feita em tubos de ensaio de $50 \mathrm{~mL}$, com OD 600 inicial igual a 0,5 e contendo 7,5 mL de meio YX40, a $28^{\circ} \mathrm{C}$ em shaker rotativo por 200 horas. Diversos pontos de 200ul foram retirados em diferentes tempos de crescimento, e a densidade celular foi lida em placas de 96 poços (ELISA) por OD 600 em espectrofotômetro Spectramax 3 (Molecular Devices). 


\section{Fermentacão em erlenmeyer}

Os testes de crescimento das linhagens foram realizados por fermentações em meio mínimo com xilose líquido YX40, para análise do perfil de crescimento e produção de metabólitos.

As linhagens foram retiradas de estoques de glicerol em freezer $-80^{\circ} \mathrm{C}$, plaqueadas em meio YG20 ágar e incubadas a $28{ }^{\circ} \mathrm{C}$ por $48 \mathrm{~h}$ em estufa bacteriológica. Posteriormente, as placas foram utilizadas como fonte para o pré-inóculo líquido, onde as leveduras foram inoculadas em $5 \mathrm{~mL}$ de meio YG20 e crescidas por $48 \mathrm{~h}$ a $28{ }^{\circ} \mathrm{C}$ em shaker rotativo a $180 \mathrm{rpm}$ (MAX Q8000 Thermo Scientific). Após este crescimento, as células foram centrifugadas (1200 g por 5 minutos), o sobrenadante foi descartado e lavado com água destilada estéril, e às células foram adicionados $5 \mathrm{~mL}$ de $\mathrm{YX} 40$, incubado a $28^{\circ} \mathrm{C}$ por à $180 \mathrm{rpm}$ em shaker rotativo.

As fermentações foram realizadas em triplicata, em frascos erlenmeyers contendo 50 $\mathrm{mL}$ de meio $\mathrm{YX} 40$, a $28^{\circ} \mathrm{C}$ em shaker rotativo por 120 horas, em que a cada $24 \mathrm{~h}$ uma amostra $(600 \mu \mathrm{l})$ da cultura foi retirada e guardada em freezer $-20{ }^{\circ} \mathrm{C}$ para futuras análises. A $\mathrm{OD}_{600}$ do inóculo de xilose foi medida e calculada forma que $\mathrm{OD}_{600}$ inicial das amostras da fermentação fossem 0,5 .

A densidade celular foi medida por $\mathrm{OD}_{600}$ em espectrofotômetro Spectramax 3 (Molecular Devices) em cuvetas de $1 \mathrm{~mL}$.

\section{Fermentacão em Biorreator}

As cofermentações foram feitas em biorreator New Brunswick ${ }^{\mathrm{TM}}$ BioFlo ${ }^{\circledR} 115$, em $900 \mathrm{~mL}$ de meio mínimo de sais suplementado com vitaminas, elementos traço e ergosterol, contendo $40 \mathrm{~g} / \mathrm{L}$ de Xilose e $20 \mathrm{~g} / \mathrm{L}$ de glicose.

As amostras foram retiradas de estoque de glicerol em freezer $-80{ }^{\circ} \mathrm{C}$ e plaqueadas em meio YG20 ágar, incubadas a $28{ }^{\circ} \mathrm{C}$ por $48 \mathrm{~h}$ em estufa bacteriológica. Posteriormente as placas foram transferidas para $5 \mathrm{~mL}$ de meio YG20 e incubadas durante a noite a $28{ }^{\circ} \mathrm{C} \mathrm{em}$ shaker rotativo $(180 \mathrm{rpm})$. Três mililitros deste pré-inoculo foram então inoculados em 100 $\mathrm{mL}$ de meio YG20/X40, crescidos também durante a noite a $28^{\circ} \mathrm{C}$ em shaker rotativo 180 rpm.

A $\mathrm{OD}_{600}$ do inóculo foi medida e calculada de forma que a $\mathrm{OD}_{600}$ inicial no biorreator fosse igual a 0,5. O crescimento foi feito por 120 horas, a $28^{\circ} \mathrm{C}, 200 \mathrm{rpm}$ e pH igual a 5,5 
mantido por adição de base (KOH 3M) quando necessário. Não houve oxigenação durante a fermentação (fermentação anaeróbia). As fermentações foram feitas em duplicatas, e a densidade celular medida por $\mathrm{OD}_{600}$ de amostras retiradas em diferentes tempos de cultura e congeladas para futuras análises. As ODs foram medidas em espectrofotômetro Spectramax 3 (Molecular Devices) em cuvetas de $1 \mathrm{~mL}$.

\section{Condicionamento de Leveduras}

O condicionamento das leveduras transformantes foi feito por transferências sucessivas das leveduras em meio mínimo seletivo (YX40). Inicialmente, cada vez que a levedura atingia $\mathrm{OD}_{600}$ igual a três, $1 \mathrm{ml}$ do crescimento era transferido para novo meio. Após dez ciclos, a cada vez que a levedura atingia crescimento de $\mathrm{OD}_{600}$ igual a três, era transferida para novo meio com $\mathrm{OD}_{600}$ final igual a 0,2 . O processo de condicionamento foi executado por aproximadamente nove meses em quarenta e três ciclos de transferência. Nos últimos dez ciclos, a levedura era transferida para novo meio a cada 24 horas. Ao final, a linhagem gerada foi denominada "condicionada".

\section{Cura de Leveduras}

A cura dos plasmídeos presentes no citoplasma das leveduras transformantes foi realizada através de transferências sucessivas das leveduras transformantes crescidas em meio completo suplementado com aminoácido de seleção.

Os transformantes condicionados foram inoculados em tubos de centrífuga de $50 \mathrm{~mL}$ contendo $5 \mathrm{~mL}$ de YPD suplementado com L-triptofano (concentração final $60 \mathrm{mg} / \mathrm{L}$ ) e crescidos a $28{ }^{\circ} \mathrm{C}$ durante a noite em shaker rotativo (180 rpm). No dia seguinte, $100 \mu \mathrm{L}$ do crescimento foram transferidos para novo tubo contendo meio suplementado. Após 10 ciclos de transferência, as leveduras foram plaqueadas em YPD para isolamento de colônia e incubadas durante a noite em estufa a $28{ }^{\circ} \mathrm{C}$. No dia seguinte, com as colônias crescidas, 52 colônias de cada levedura transformante foram escolhidas e isoladas no teste de cura.

\subsection{Teste de Cura}

O teste da cura foi feito em placas de meio YPD e YG20 ágar, utilizando mapa de placa de Petri quadriculado e numerado. Cada colônia isolada da placa de YPD foi resgatada com palito e plaqueada em um mesmo espaço numerado tanto em meio YG20 quanto em 
YPD, nesta ordem. As placas com o mapa foram incubadas em estufa a $28{ }^{\circ} \mathrm{C}$ até que as colônias crescessem.

\subsection{Teste fisiológico de confirmação da cura}

As linhagens curadas foram submetidas a um teste fisiológico para confirmar a perda de capacidade de crescer em meio mínimo e de utilizar xilose como fonte de carbono.

As amostras das três linhagens condicionadas e curadas foram plaqueadas em meio YG20 e incubadas em estufa bacteriológica a $30{ }^{\circ} \mathrm{C}$ durante a noite. A partir das placas, uma quantidade equivalente a uma colônia de cada uma das linhagens foi inoculada em três tubos, cada um contendo $5 \mathrm{~mL}$ de meio YPX, YG20 ou YX40.

Amostras de $200 \mu \mathrm{L}$ foram retiradas a cada 24 horas, e a densidade celular foi lida em placas de 96 poços (ELISA) por OD $_{600}$ em espectrofotômetro Spectramax 3 (Molecular Devices).

\section{Análise de metabólitos - HPLC}

A análise quantitativa dos metabólitos produzidos (etanol, glicerol, ácido acético e xilitol) e consumo de substrato (glicose e/ou xilose) nas fermentações foi feita por cromatografia líquida de alta eficiência (HPLC). As amostras retiradas nos diferentes tempos das fermentações foram centrifugadas, diluídas duas vezes em água Milli-Q e injetadas em cromatógrafo Agilent 1260 Infinity utilizando coluna Aminex HPX-87H (Bio-Rad) aquecido

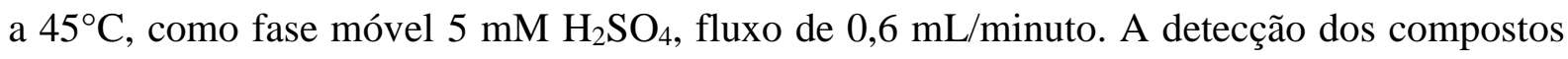
foi efetuada por detector de índice de refração. O software utilizado foi o Agilent Openlab Control Panel para análise dos cromatogramas. A quantificação dos compostos foi realizada ao comparar os mapas gerados com mapas de padrões com concentrações definidas dos compostos de interesse.

\section{Atividade enzimática}

\subsection{Preparo de extrato celular}

As amostras foram plaqueadas em meio YG20 e incubadas em estufa bacteriológica a $30{ }^{\circ} \mathrm{C}$ por 48 horas. A partir das placas foi feito um inóculo em $20 \mathrm{~mL}$ de meio YG20 em erlenmeyers de $100 \mathrm{~mL}$, incubados por 48 horas a $28{ }^{\circ} \mathrm{C}$ em shaker rotativo a $180 \mathrm{rpm}$ (MAX Q8000 Thermo Scientific). As células foram então centrifugadas, lavadas com água destilada estéril e inoculadas em 20 mL de YX40 nas mesmas condições por 24 horas. Após incubação, 
as células foram centrifugadas (10.000 X $g$ por 5 minutos) e lavadas com água destilada estéril. As células foram ressuspendidas em $500 \mu \mathrm{L}$ de Y-PER TM (Yeast Protein Extraction Reagent - Life Technologies) e incubadas por 30 minutos em plataforma oscilante à temperatura ambiente. As amostras foram então centrifugadas a $10.000 \mathrm{~g}$ por 10 minutos a 4 ${ }^{\circ} \mathrm{C}$. O sobrenadante foi transferido para um novo tubo, mantido em gelo, e utilizado como substrato do ensaio enzimático.

\subsection{Atividade enzimática}

$\mathrm{O}$ ensaio de atividade enzimática de $\mathrm{XK}$ foi feito segundo protocolo descrito em LUCCIO et al. (2007).

O ensaio foi realizado à temperatura ambiente, em tampão Hepes $50 \mathrm{mM}$ contendo $10 \mathrm{mM} \mathrm{MgCl}_{2}, 50 \mathrm{mM} \mathrm{KCl}$ e BSA $1 \mathrm{mg} / \mathrm{mL}$. Ao tampão, foram adicionados os seguintes reagentes, (com suas respectivas concentrações finais na reação) NADH $0,3 \mathrm{mM}$, Fosfoenolpiruvato $1 \mathrm{mM}$, ATP 5mM, D-xilulose 4,3mM, Piruvato quinase $3 \mathrm{U} / \mathrm{mL}$, Lactato desidrogenase 5,4U/mL. Ao final foi adicionado $50 \mu \mathrm{L}, 75 \mu \mathrm{L}$ ou $100 \mu \mathrm{L}$ de extrato celular para os ensaios. O volume final da reação foi de $1 \mathrm{~mL}$.

A reação ocorre uma vez que o substrato (D-xilulose) é convertido a D-xilulose-5fosfato pela XK presente no extrato celular, ao custo de um ATP. O ADP liberado é utilizado pela piruvato quinase para converter o fosfoenolpiruvato à piruvato, e este é reduzido a Dlactato pela lactato desidrogenase, ao custo de um NADH. A depleção do NADH é medida a $340 \mathrm{~nm}$ por 10 minutos.

O controle da atividade enzimática foi feito ao adicionar todos os componentes da reação exceto o extrato celular, em que não deve haver depleção do NADH.

\subsection{Normalização por curva de Bradford}

O ensaio foi normalizado pela quantidade de proteína presente no substrato, através de curva de Bradford (Sigma - Aldrich) feita com BSA, medido a 595nm com espectrofotômetro, de acordo com as instruções do fabricante.

\subsection{Análise estatística}

Foi aplicado um teste estatístico One-Way ANOVA com pós teste Tukey para comparar se as diferenças entre as atividades de XK das diferentes linhagem eram 
estatisticamente significativas. O nível de significância adotado para as análises foi de $5 \%$. O teste foi realizado em plataforma online (VASAVADA, 2014).

\section{Sequenciamento da XIPiro condicionada}

As amostras foram sequenciadas através de metodologia Sanger (SANGER; COULSON, 1975) pela empresa Eurofins Genomics, utilizando o par de oligonucleotídeos 11/12 (Tabela 3) para amplificação de XI.

O software utilizado para análise do sequenciamento foi o Geneious 8.1 (disponível em Geneious website - http://www.geneious.com/ (KEARSE et al., 2012).

No Geneious as sequências foram visualizadas e as extremidades de baixa qualidade foram removidas. Para os plasmídeos das linhagens L7XIФ e L7XIXK foram gerados contigs a partir das dos dez fragmentos (cinco 5 ' terminal e cinco 3 ' terminal) sequenciados. Para o plasmídeo da linhagem L2XI e p424-XI foi montado um contig a partir dos fragmentos (5' terminal e 3 'terminal) sequenciados. Os contigs foram alinhados utilizando a ferramenta MUSCLE.

Foi feito um BLASTx da sequência consenso formada pelo alinhamento dos quatro contigs (p424, L2XI, L7XIФ, L7XIXK contra banco de dados de proteína (nr).

\subsection{Preparação de amostras para sequenciamento}

Os plasmídeos das leveduras condicionadas a serem sequenciados foram extraídos através do protocolo de extração de DNA plasmidial de levedura. O DNA extraído foi utilizado para transformar a E. coli por eletroporação, e, a partir das placas da transformação, foram selecionadas colônias de cada grupo transformado.

Para análise do gene da amostra de L2XI condicionado, DNA foi extraído da levedura e amplificado por PCR com par de oligonucleotídeos 11/12 (Tabela 3) para XI.

Todas as amostras de DNA sequenciadas foram previamente purificadas com kit GeneJET PCR purification Kit (Thermo Scientific). 


\section{RESULTADOS}

\section{Construcão de linhagens de Saccharomyces cerevisiae capazes de consumir xilose}

\subsection{Clonagem dos genes XKS1 e XylA}

Para construção de linhagens recombinantes de $S$. cerevisiae capazes de consumir xilose, foi escolhida a via da xilose isomerase. Além disso, o efeito da superexpressão da enzima xiluloquinase foi avaliado. Os genes $X y l A$ e $X K S 1$ foram clonados nos vetores p424 e p426, respectivamente. Para tanto, o gene XylA de Piromyces sp. (XIPiro), previamente descrito foi amplificado por PCR com os oligonucleotídeos para amplificação de XIPiro (7/8 - Tabela 3) utilizando plasmídeo pRH218 (Tabela 4) como molde. O gene XKS1 que codifica XK de S. cerevisiae também foi amplificado por PCR com o par de oligonucleotídeos para amplificação de XK (9/10 - Tabela 3), utilizando o plasmídeo pRH195, como molde (Tabela 4). Para ambos os genes, os sítios de restrição para SpeI e SalI foram inseridos nas extremidades 5' e 3', respectivamente. A banda XI de Piromyces de aproximadamente 1,4 kb referente ao gene XIPiro e a banda de aproximadamente $1,8 \mathrm{~kb}$ referente ao gene de XK (Figura 3).

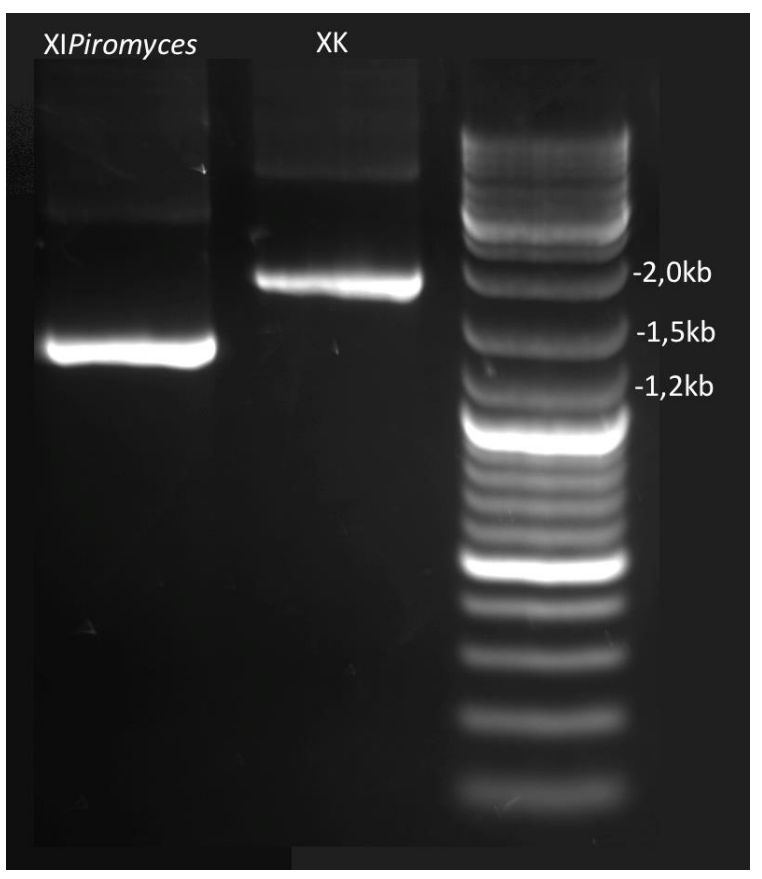

Figura 3: Confirmação da amplificação dos genes XIPiro $(1,4 \mathrm{~kb})$ e XK $(1,8 \mathrm{~kb})$. Análise eletroforética em gel de agarose 1\%. Marcador de massa molecular Gene Ruler DNA Ladder Mix (Thermo). 
Posteriormente plasmídeos epissomais para a expressão dos genes de interesse na levedura foram construídos (Figuras 4 e 5). O gene de XIPiro foi clonado no plasmídeo p424 (Tabela 4) linearizado previamente nos sítios de restrição SalI/SpeI, sob controle do promotor GPD, terminador Cyc e marca de seleção para TRP. O gene XK foi clonado no plasmídeo p426 (Tabela 4) linearizado previamente em SpeI/SalI sob controle do promotor TEF, terminador Cyc e marca de seleção para URA (Figura 5).

Os sistemas de ligação de p424-XI e p426-XK foram transformados por eletroporação em E. coli e plaqueados em LB com ampicilina. A confirmação da clonagem foi realizada por restrição dos mesmos com o par de enzimas SalI e SpeI utilizados na construção e análise eletroforética em gel de agarose.

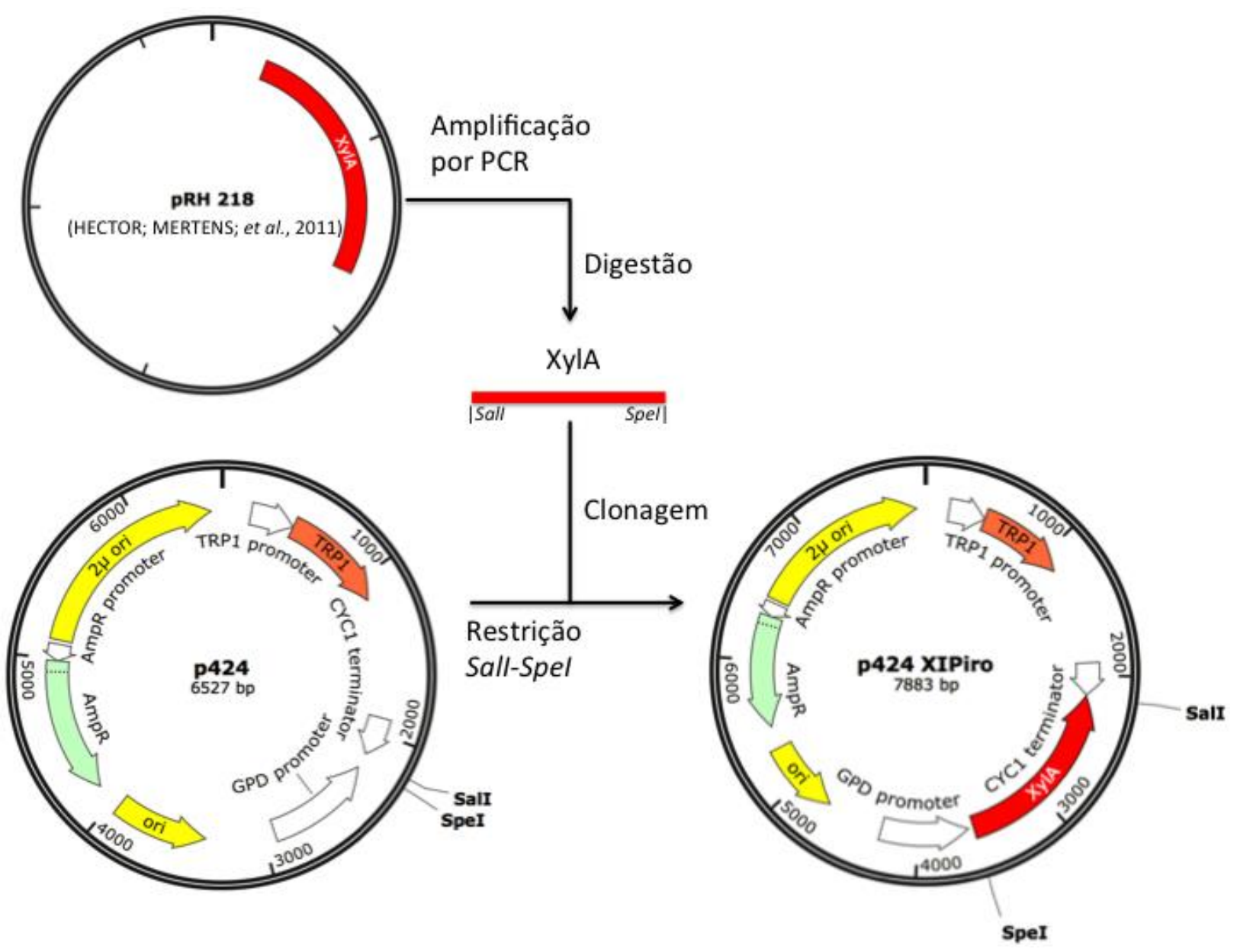

Figura 4: Estratégia de construção do plasmídeo p424-XI. O plasmídeo p42a apresenta 6,5 kb e o gene XKS1 1,4 kb. O plasmídeo gerado (p424-XIPiro) tem 7,8 kb. 


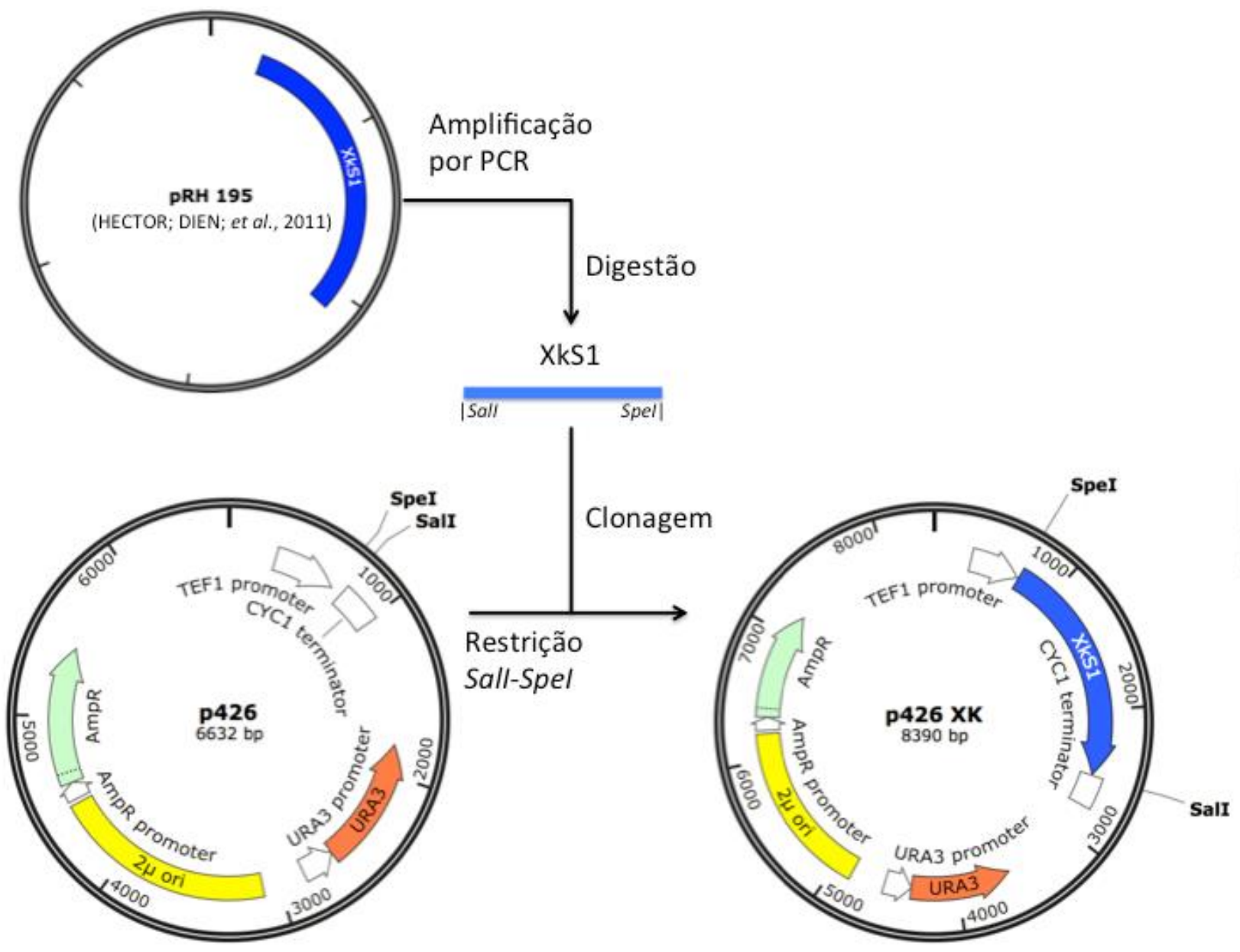

Figura 5 Estratégia de clonagem para a construção do plasmídeo p426-XK. O plasmídeo p426 apresenta 6,6 kb e o gene XKS1 1,8 kb. O plasmídeo gerado (p426-XK) tem 8,3kb.

\subsection{Transformação em de Levedura}

Os vetores de expressão construídos foram utilizados para transformar duas linhagens isogênicas de S. cerevisiae, CEN.PK 113-3C (Levedura 2) e CEN.PK 113-14A (Levedura 7) conforme Tabela 2. Os transformantes obtidos foram selecionados por sua capacidade de crescer em meio mínimo sem aminoácidos (YNB) contendo glicose como única fonte de carbono. As linhagens construídas estão descritas na Tabela 5.

Também foram gerados dois controles negativos, através da transformação das mesmas linhagens, com os vetores de expressão p424, e p424 combinado com p426, porém

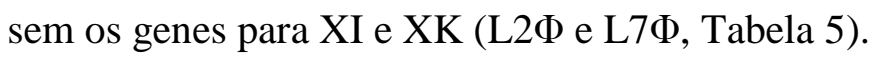


Tabela 5: Linhagens de $S$. cerevisiae transformantes geradas no trabalho, pela inserção dos vetores construídos.

\begin{tabular}{|c|c|c|}
\hline Linhagem & Linhagem original & Genótipo \\
\hline L2Ф & CEN.PK 113.C & $\begin{array}{l}\text { CEN.PK113.C MATa, trp1-289, MAL2- } \\
8 C, S U C 2, \text { p424::TRP }\end{array}$ \\
\hline L2XI & CEN.PK 113.C & $\begin{array}{l}\text { CEN.PK113.C , MATa, trp1-289, MAL2- } \\
8 C, \text { SUC2, p424-XylA::TRP }\end{array}$ \\
\hline L7 $\Phi$ & CEN.PK 113.14A & $\begin{array}{l}\text { CEN.PK113.14A MATa, ura3-52, trp1- } \\
\text { 289, MAL2-8C, SUC2 p424::TRP } \\
\text { p426::URA }\end{array}$ \\
\hline L7XIФ & CEN.PK 113.14A & $\begin{array}{l}\text { CEN.PK113.14A MATa, ura3-52, trp1- } \\
\text { 289, MAL2-8C, SUC2 p424-XylA::TRP } \\
\text { p426::URA }\end{array}$ \\
\hline L7XIXK & CEN.PK 113.14A & $\begin{array}{l}\text { CEN.PK113.14A MATa, ura3-52, trp1- } \\
\text { 289, MAL2-8C, SUC2 p424 - XylA::TRP } \\
\text { p426 - XKS1::URA }\end{array}$ \\
\hline
\end{tabular}

Os transformantes, contendo o plasmídeo com o gene responsável por complementar a marca auxotrófica, foram capazes de crescer em glicose. Os controles (L2Ф e L7Ф) não cresceram em meio mínimo com xilose como a única fonte de carbono. A seguir foi feito um teste de crescimento com as cinco linhagens em meio mínimo (YNB) com xilose (40 g/L) como única fonte de carbono (Figura 6). 


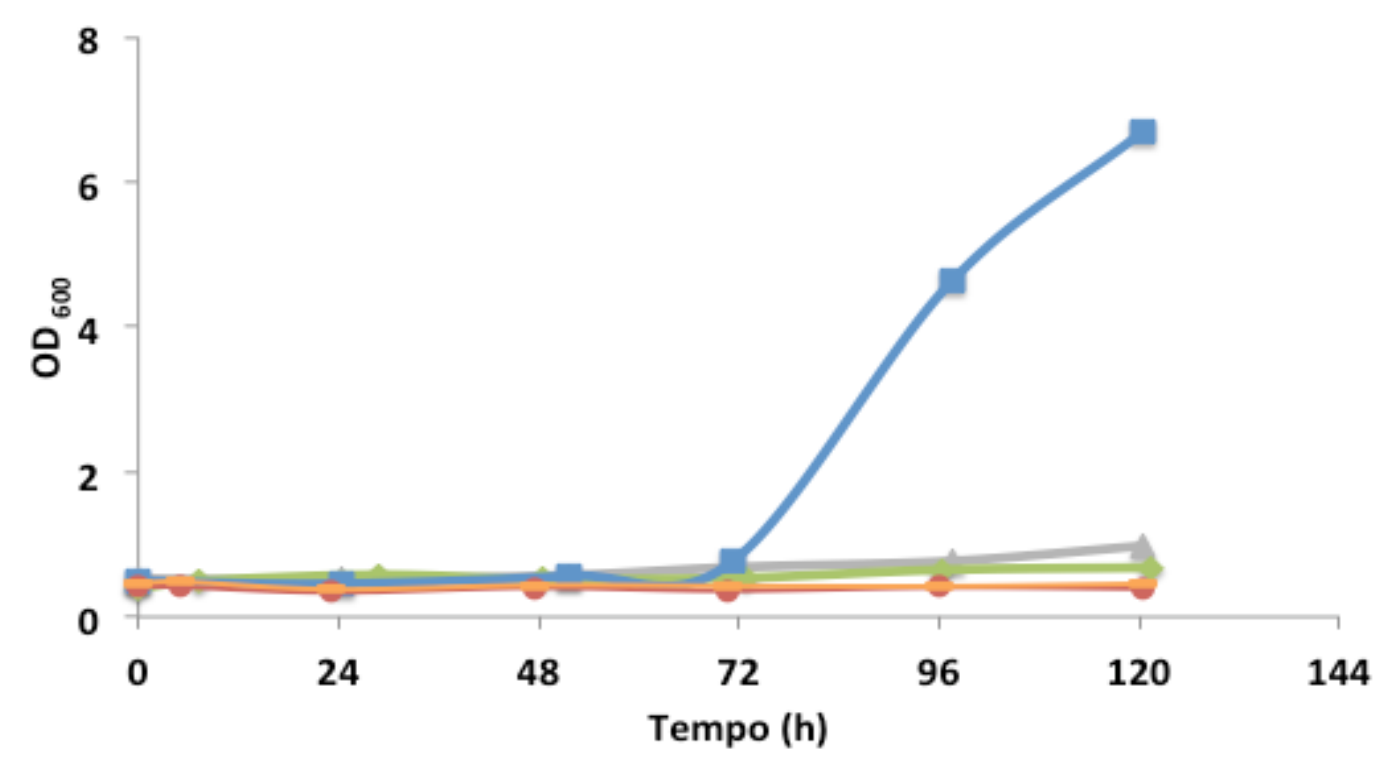

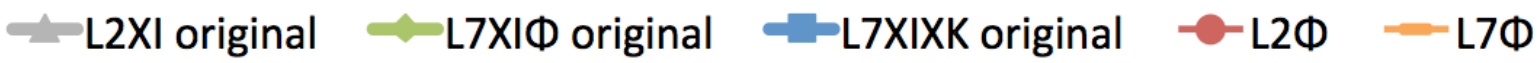

Figura 6: Teste de crescimento das leveduras transformantes geradas. Transformantes L2 $\Phi$ (vermelho) e L7Ф (laranja) contendo respectivamente os plasmídeos p424 e p424/p426, vazios e as amostras transformantes L2XI (cinza) L7XIФ (verde) e L7XIXK (azul) expressando genes do catabolismo de xilose. Cada gráfico é um exemplo representativo de fermentação aeróbica feito em duplicata por 120 horas.

Como esperado, não houve crescimento para as amostras controle L2Ф e L7Ф. A linhagem a L7XIXK iniciou crescimento exponencial por volta de 72 horas (Figura 6), enquanto o crescimento das linhagens L2XI e L7XI $\Phi$, só iniciou apos 120 horas de crescimento (dados não mostrados).

\subsection{Melhoramento genético por evolução adaptativa}

As linhagens obtidas após as transformações foram submetidas a processo de evolução adaptativa (condicionamento), em meio mínimo com xilose como única fonte de carbono, como estratégia de melhoramento genético para o consumo de xilose. O condicionamento consistiu de sucessivas transferências da levedura crescida para um novo frasco contendo o mesmo meio.

Inicialmente, $1 \mathrm{~mL}$ do crescimento foi transferido cada vez que atingiu $\mathrm{OD}_{600}$ igual a 
três. Após dez ciclos com esta abordagem, as transferências foram feitas para que a $\mathrm{OD}_{600}$ inicial no novo frasco fosse de 0,2 para todos.

Nos últimos dez ciclos de condicionamento, foi adotada a estratégia de transferir a levedura para novo meio a cada 24 horas, com a pressão seletiva voltada para àquelas que começassem a crescer mais rapidamente. No total, o processo de condicionamento foi feito por aproximadamente nove meses. Ao final foram obtidas as linhagens condicionadas dos três transformantes L2XI, L7XIФ e L7XIXK condicionados.

Um teste de crescimento foi realizado para comparar as três populações de leveduras condicionadas, com os três transformantes originais de L2XI, L7XIФ e L7XIXK e avaliar os efeitos do processo adaptativo (Figura 7).

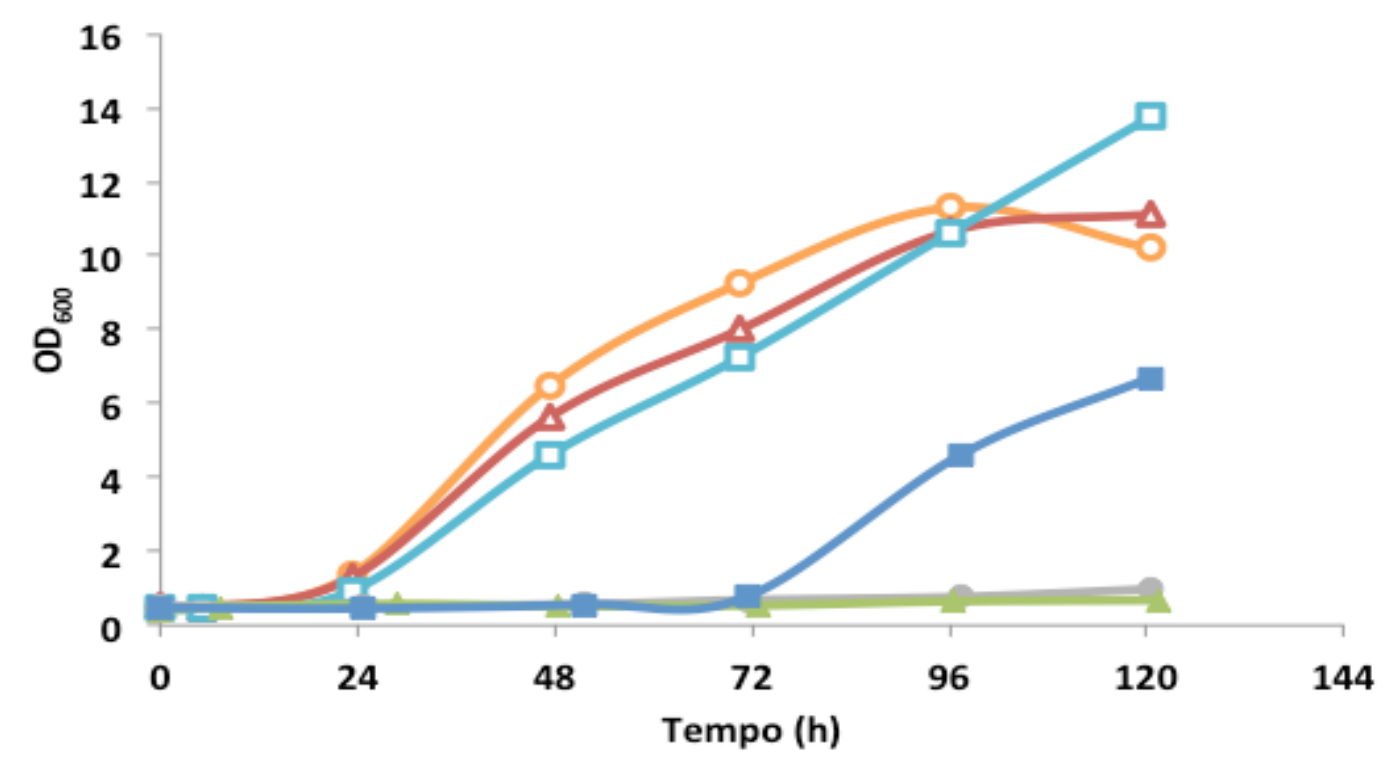

O-pL2XI pop - -L7XIФ pop - -L7XIXK pop - L2XI original - L7XIФ original - L7XIXK original

Figura 7: Teste de crescimento entre transformantes isolados originais L2XI (cinza) L7XIФ (verde) e L7XIXK (azul) e população de transformantes condicionados L2XI (laranja) L7XIФ (vermelho) e L7XIXK (turquesa). Cada linha é um exemplo representativo de fermentação aeróbica $\left(50 \mathrm{~mL}\right.$ YX40 em frasco de $100 \mathrm{~mL}, \mathrm{OD}_{600}$ inicial: 0,5) feito em duplicata por 120 horas.

Foram observadas duas principais diferenças no padrão de crescimento entre os isolados de transformantes originais e as populações de transformantes condicionadas.

Para todas as linhagens condicionadas, o crescimento em xilose começou após 24 
horas de incubação, enquanto o crescimento de L7XIXK original começou após 72 horas, e L2XI e L7XIФ tiveram crescimento, ainda muito lento, após 120 horas.

A segunda diferença marcante, também para todas as linhagens, se refere à densidade celular final alcançada. Todas as linhagens condicionadas atingiram $\mathrm{OD}_{600}$ final igual ou maior que 10. L2XI e L7XIФ entraram em fase estacionária por volta de 96 horas, enquanto L7XIXK continuou em fase exponencial até 120 horas. A linhagem original L7XIXK, que teve maior crescimento dentre todas, chegou à $\mathrm{OD}_{600}$ máxima igual a 7,3 $\pm 1,2$ em 120 horas. As linhagens L2XI e L7XI $\Phi$ originais atingiram $\mathrm{OD}_{600}$ igual a $0,62 \pm 0,1$ e $0,77 \pm 0,05$, respectivamente.

Considerando que as populações condicionadas apresentam variabilidade genética, procedeu-se com o isolamento de clones que representassem o perfil melhorado da população. As amostras condicionadas foram plaqueadas em meio mínimo YX40, e seis colônias de cada uma das linhagens foram selecionadas baseado na sua capacidade de crescer em xilose após incubação de 48 horas.

Posteriormente, o perfil de crescimento em xilose das colônias isoladas de cada uma das populações foi analisado (Figura 8). As colônias não tiveram aparente diferença significativa no perfil de crescimento em nenhum dos três grupos. Entretanto, a colônia de número seis, nos três crescimentos, foi a última a atingir fase estacionária. Portanto, de cada linhagem (L2, L7XIФ e L7XIXK), a colônia isolada de número seis foi escolhida como fenótipo representativa da população para desenvolvimento das etapas posteriores do trabalho.

A confirmação de que os isolados selecionados apresentavam o gene de XIPiro foi feita por PCR de colônia, pela amplificação de XI com par de oligonucleotídeos 11/12 (Tabela 3, Figura 9). 
A

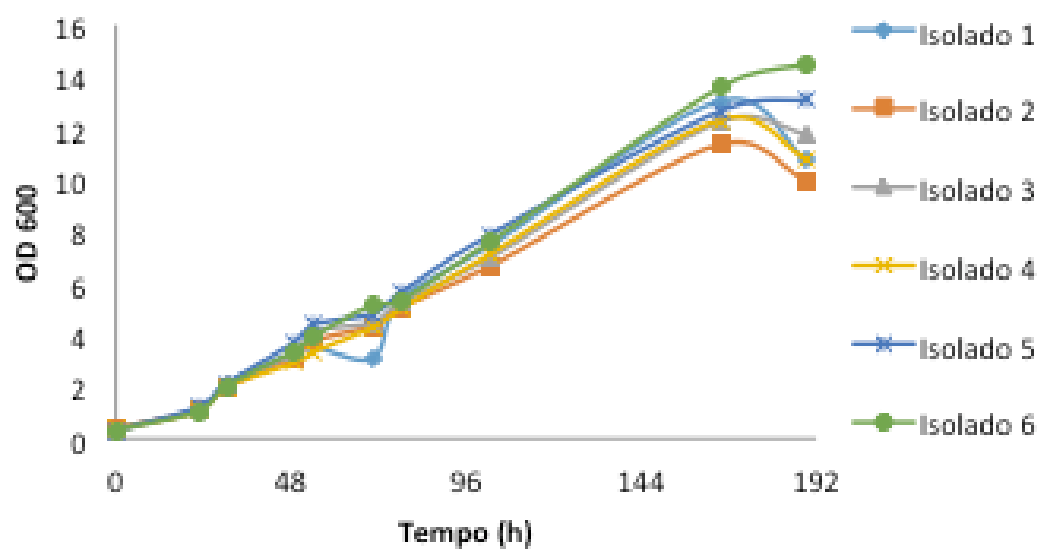

B
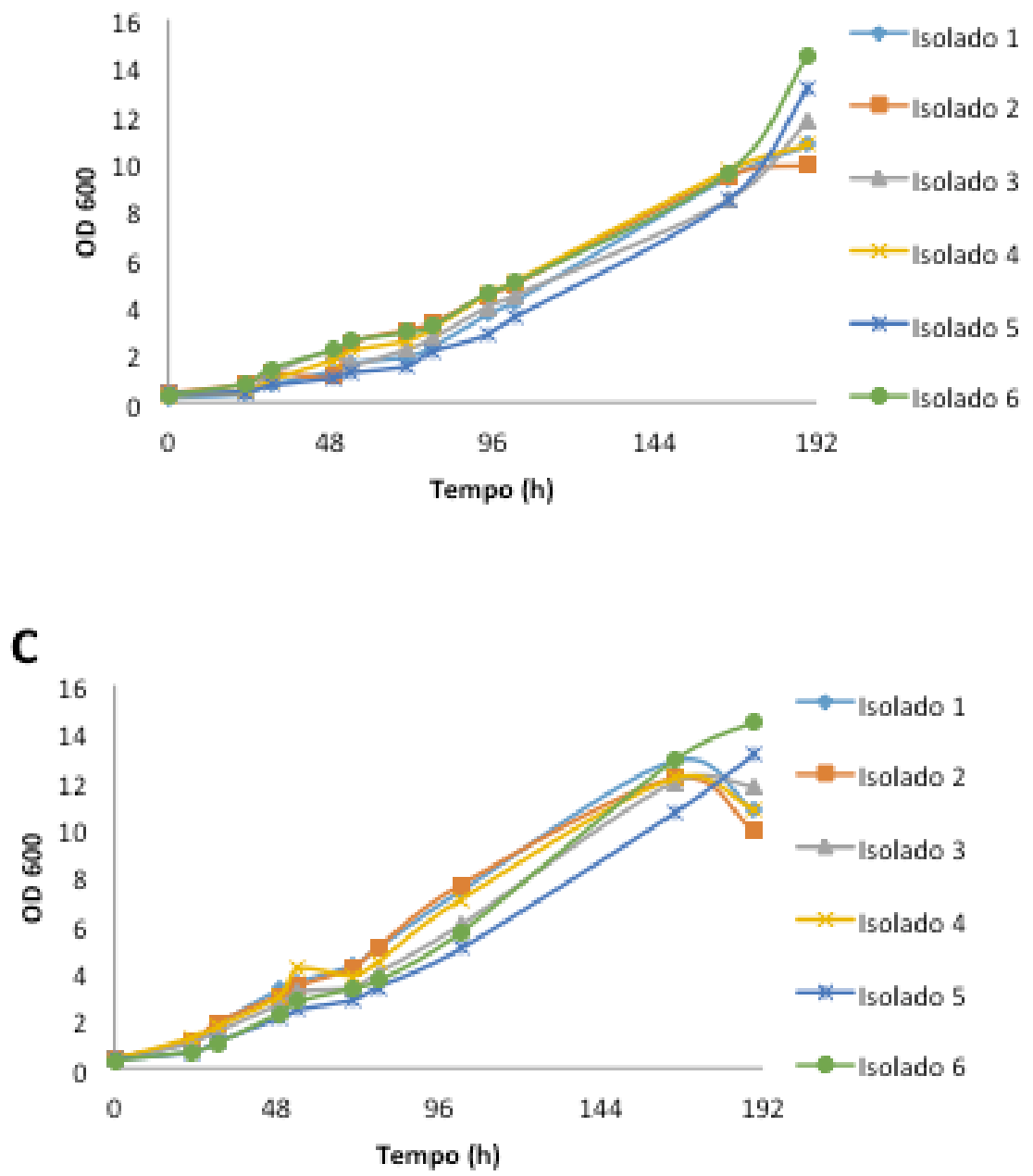

Figura 8: Curva de crescimento de seis colônias isoladas das linhagens obtidas a partir de cada população de condicionadas: L2XI Condicionada (A), L7XI Ф Condicionada (B) e L7XIXK Condicionada (C). 


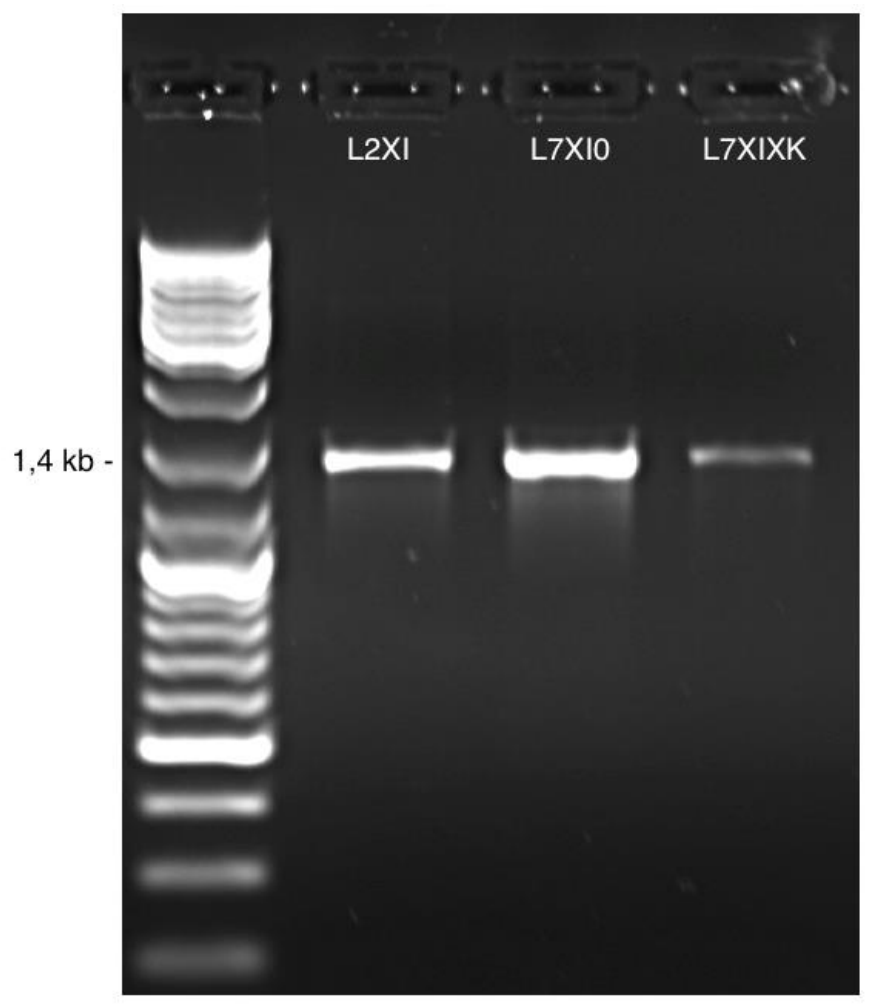

Figura 9: Confirmação da presença do gene XIPiro nos isolados condicionados. Análise eletroforética em gel de agarose 1\%. PCR de colônia das amostras condicionadas de L2XI, L7XIФ e L7XIXK, com oligonucleotídeos 11/12. As bandas de aproximadamente 1,4kb são referentes ao gene XIPiro. Marcador de massa molecular Gene Ruler DNA Ladder Mix (Thermo).

As PCRs confirmaram a presença dos genes para XI nas leveduras condicionadas. Para verificar a presença de XK nos isolados L7XIФ e L7XIXK, foi feita uma PCR com par de oligonucleotídeos 3/2 (Tabela 3). Neste caso, foi feita tanto a PCR de colônia, como a PCR do plasmídeo extraído da levedura (Figura 10).

A PCR de colônia apresentou banda de aproximadamente 750 bp referente à amplificação do promotor, sítio de clonagem múltipla (MCS) e terminador, para ambas linhagens L7XIФ (L7XI0b) e L7XIXK (L7XIXKb), mas nenhuma banda indicando a presença do gene de XK. Entretanto, a PCR do plasmídeo extraído da levedura condicionada L7XIXK, revelou banda de aproximadamente $2,5 \mathrm{~kb}$, referente ao gene para XK $(1,8 \mathrm{~kb})$, o promotor, MCS e terminador (L7XIXKa). A mesma banda de 750bp foi encontrada na PCR do plasmídeo extraído de L7XIФ, indicando que este possui o plasmídeo, entretanto sem o gene para XK, enquanto a L7XIXK apresenta o plasmídeo construído com XK (L7XI0a). 


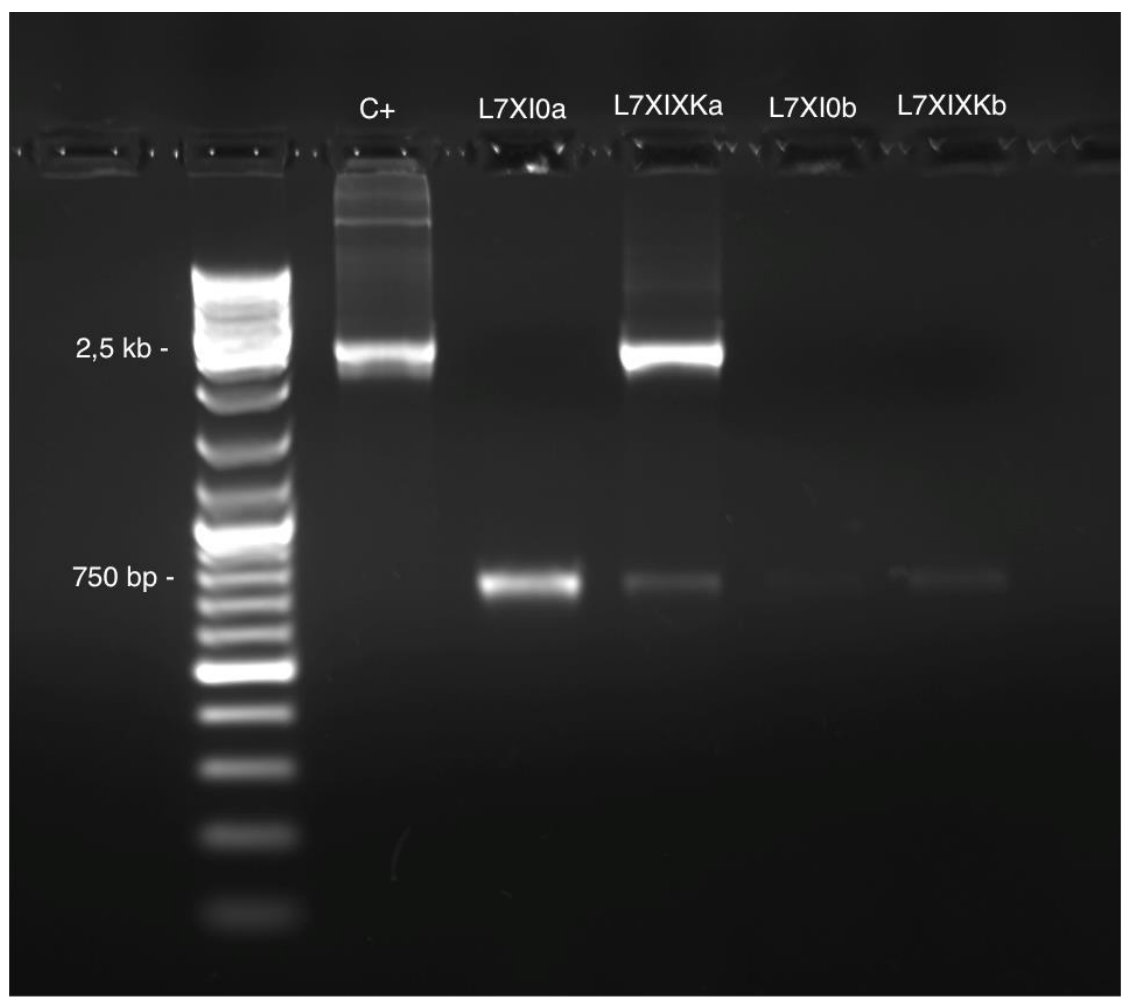

Figura 10: Confirmação da presença do gene XK nos isolados condicionados. Análise eletroforética em gel de agarose $1 \%$ para verificação da presença do gene de XK (2,5 kb) nos isolados condicionados L7XIФ ("a" e "b") e L7XIXK ("a" e "b") com oligonucleotídeos 2/3. As amostras "a" são referentes aos plasmídeos extraídos da levedura por mini-preparação como molde para PCR. As amostras "b" são referentes à PCR de colônia. O controle da PCR $(\mathrm{C}+)$ é referente à amplificação do gene no plasmídeo construído p426-XK como molde. Marcador de massa molecular Gene Ruler DNA Ladder Mix (Thermo).

A amostra L7XIXKb, em que não houve amplificação do gene de XK em L7XIXK observada na amostra L7XIXKa, pode ser devido a um problema na preparação das células para a PCR de colônia. Precisamente por ter tido problemas na PCR de colônia em eventos anteriores, foram adotadas duas estratégias para análise da presença do gene. 


\subsection{Avaliação do perfil de crescimento e capacidade fermentativa das linhagens construídas}

Após a seleção do isolado de cada linhagem condicionada, foram realizadas fermentações para avaliar o perfil de crescimento e produção de metabólitos das linhagens originais e condicionadas (Figura 11).
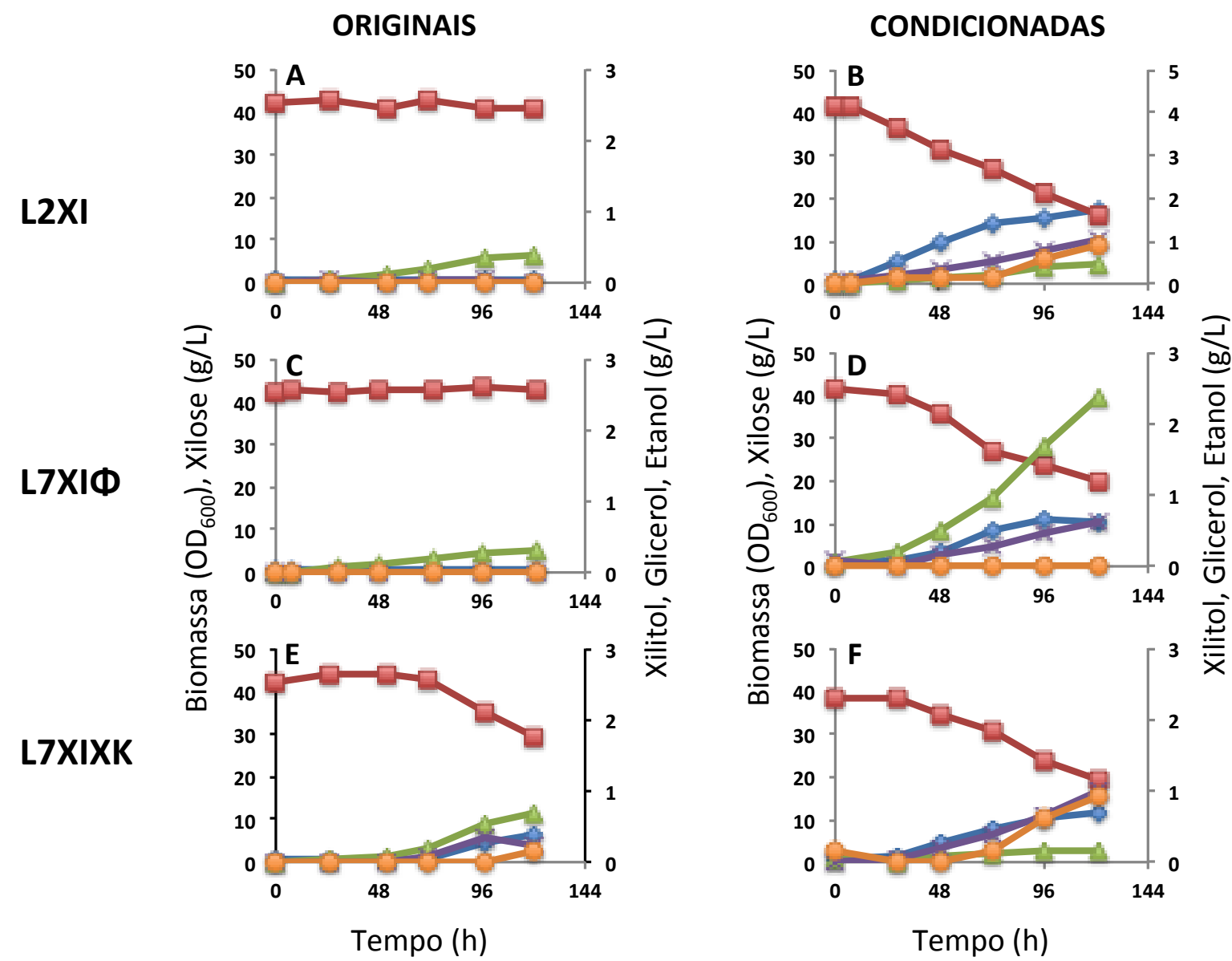

$\leadsto$ Biomassa (OD600) $\square$ Xilose $\leadsto$ Xilitol $*$ Glicerol $\sim$ Etanol

Figura 11: Teste de crescimento das linhagens transformantes originais $(\mathrm{A}, \mathrm{C}, \mathrm{E}) \mathrm{e}$ condicionadas (B, D, G). Consumo de xilose (vermelho), formação de biomassa (azul), xilitol (verde), etanol (laranja), e glicerol (roxo), durante fermentação aeróbica das linhagens L2XI Original e Condicionada (A, B), L7XIФ Original e Condicionada (C, D), e L7XIXK Original e Condicionada (E, F). Não houve produção de ácido acético em nenhuma das linhagens. Cada gráfico é um exemplo representativo de fermentação aeróbica com $\mathrm{OD}_{600}$ inicial de 0,5 feito em triplicata. 
A principal diferença observada entre as linhagens originais e condicionadas foi o consumo da xilose. Enquanto as linhagens condicionadas utilizam xilose, e tem crescimento de biomassa $\left(\mathrm{OD}_{600}\right)$ iniciado por volta de 24 horas, as leveduras originais levaram pelo menos 72 horas para começar a consumir xilose e crescer. Esta diminuição da fase Lag de crescimento é observado nas três linhagens do grupo de condicionadas quando comparadas com as originais. É importante notar que o crescimento final foi maior para todas as linhagens condicionadas, com maior diferença na densidade celular $\left(\mathrm{OD}_{600}\right)$ entre as linhagens L2XI condicionada $(19,3 \pm 2,3)$ e original $(0,84 \pm 0,1)$.

Nenhum dos dois grupos consome totalmente os $40 \mathrm{~g} / \mathrm{L}$ de xilose disponíveis no meio ao final das 120 horas, entretanto, enquanto as linhagens condicionadas consumiram entre $50 \%$ e $60 \%$ do total de xilose, as linhagens originais consumiram 2,97\% (L2XI), 6,06 (L7XIФ) e 32,23\% (L7XIXK).

A linhagem L7XIФ foi a única do grupo de condicionadas a não produzir etanol. Entretanto, sua produção de xilitol foi maior que todas as outras linhagens, chegando a concentração final de 2,12 $\pm 0,86 \mathrm{~g} / \mathrm{L}$. O rendimento de xilitol da linhagem condicionada reduziu 12 vezes quando comparado com a original.

As concentrações finais de produtos, rendimentos, produtividade e taxa de consumo de substrato estão resumidos nas Tabelas 6 e 7.

Com o intuito de investigar melhor os metabólitos produzidos por cada uma das linhagens, fermentações anaeróbicas com alta densidade celular foram realizadas $\left(\mathrm{OD}_{600}\right.$ inicial igual a 10, Figura 12).

Nenhuma das linhagens consome totalmente xilose, entretanto as linhagens originais têm consumo entre $27,9 \%$ e 46,24\% enquanto as condicionadas têm consumo entre 53,4\% e $78,7 \%$, sendo que a linhagem L7XIФ foi novamente a que menos consumiu. 
Tabela 6: Concentração final de xilose consumida e de produtos formados.

\begin{tabular}{|c|c|c|c|c|c|c|c|c|c|c|c|c|}
\hline \multirow{2}{*}{ Linhagem } & \multicolumn{2}{|c|}{ Xilose consumida $\mathrm{g} / \mathrm{L}$} & \multicolumn{2}{|c|}{ Etanol g/L } & \multicolumn{2}{|c|}{ Ácido acético g/L } & \multicolumn{2}{|c|}{ Glicerol g/L } & \multicolumn{2}{|c|}{ Xilitol g/L } & \multicolumn{2}{|c|}{ Biomassa $\mathrm{g} / \mathrm{L}$} \\
\hline & Média & Desv Pad & Média & Desv Pad & Média & Desv Pad & Média & Desv Pad & Média & Desv Pad & Média & Desv Pad \\
\hline L2XI Original & 1,19 & 0,35 & 0,00 & 0,00 & 0,00 & 0,00 & 0,01 & 0,01 & 0,38 & 0,05 & 0,18 & 0,05 \\
\hline L2XI Condicionada & 22,07 & 3,19 & 0,60 & 0,41 & 0,02 & 0,03 & 0,70 & 0,37 & 0,85 & 0,73 & 11,91 & 4,03 \\
\hline L7XIФ Original & 2,43 & 2,25 & 0,00 & 0,00 & 0,00 & 0,00 & 0,01 & 0,00 & 0,27 & 0,03 & 0,11 & 0,01 \\
\hline L7XIФ Condicionada & 19,93 & 3,75 & 0,21 & 0,37 & 0,03 & 0,06 & 0,55 & 0,12 & 2,12 & 0,86 & 5,11 & 0,53 \\
\hline L7XIXK Original & 12,89 & 5,45 & 0,49 & 0,57 & 0,01 & 0,02 & 0,37 & 0,16 & 0,76 & 0,13 & 3,24 & 0,56 \\
\hline L7XIXK Condicionada & 24,21 & 5,29 & 1,18 & 0,64 & 0,03 & 0,05 & 1,24 & 0,67 & 0,13 & 0,03 & 5,32 & 0,40 \\
\hline
\end{tabular}

Médias referentes a triplicatas biológicas. "Desv Pad” é referente a desvio padrão.

Tabela 7: Taxa de crescimento e rendimento em gramas de produto formado por grama de substrato (xilose) consumido em fermentação aeróbia de baixa OD $_{600}$ inicial.

\begin{tabular}{|c|c|c|c|c|c|c|c|c|c|c|c|c|}
\hline \multirow{3}{*}{ Linhagem } & \multirow{2}{*}{\multicolumn{2}{|c|}{$\begin{array}{l}\text { Taxa de crescimento } \\
\qquad\left(\mathrm{h}^{-1}\right)\end{array}$}} & \multicolumn{8}{|c|}{ Rendimento (g. $\mathrm{g}^{-1}$ ) } & \multirow{2}{*}{\multicolumn{2}{|c|}{$\begin{array}{c}\text { Taxa de consumo } \\
\text { específico de xilose } \\
\left(\mathrm{g} \cdot \mathrm{g}^{-1} \cdot \mathrm{h}^{-1}\right)\end{array}$}} \\
\hline & & & \multicolumn{2}{|c|}{ Etanol } & \multicolumn{2}{|c|}{ Glicerol } & \multicolumn{2}{|c|}{ Xilitol } & \multicolumn{2}{|c|}{ Biomassa } & & \\
\hline & Média & Desv Pad & Média & Desv Pad & Média & Desv Pad & Média & Desv Pad & Média & Desv Pad & Média & Desv Pad \\
\hline L2XI Original & $0,02 * *$ & 0,00 & 0,00 & 0,00 & 0,01 & 0,00 & 0,34 & 0,11 & 0,15 & 0,05 & 0,05 & 0,01 \\
\hline L2XI Condicionada & 0,03 & 0,02 & 0,03 & 0,02 & 0,03 & 0,01 & 0,04 & 0,04 & 0,53 & 0,10 & 0,02 & 0,00 \\
\hline L7XIФ Original & n.c. & n.c. & 0,00 & 0,00 & 0,03 & 0,04 & 1,27 & 2,06 & 0,46 & 0,73 & 0,19 & 0,19 \\
\hline L7XIФ Condicionada & $0,01 * *$ & 0,00 & 0,01 & 0,02 & 0,03 & 0,00 & 0,10 & 0,03 & 0,26 & 0,04 & 0,03 & 0,01 \\
\hline L7XIXK Original & 0,01 & 0,00 & 0,03 & 0,03 & 0,03 & 0,01 & 0,06 & 0,02 & 0,27 & 0,09 & 0,03 & 0,01 \\
\hline L7XIXK Condicionada & 0,03 & 0,00 & 0,05 & 0,02 & 0,05 & 0,02 & 0,01 & 0,00 & 0,23 & 0,05 & 0,04 & 0,01 \\
\hline
\end{tabular}

Médias referentes a triplicatas biológicas. "Desv Pad" é referente a desvio padrão.

n.c.: taxa não calculada

*O rendimento de ácido acético, produtividade de ácido acético, etanol, glicerol e xilitol não foram detectados.

** Taxa de crescimento calculado a partir de duplicata de fermentações. 


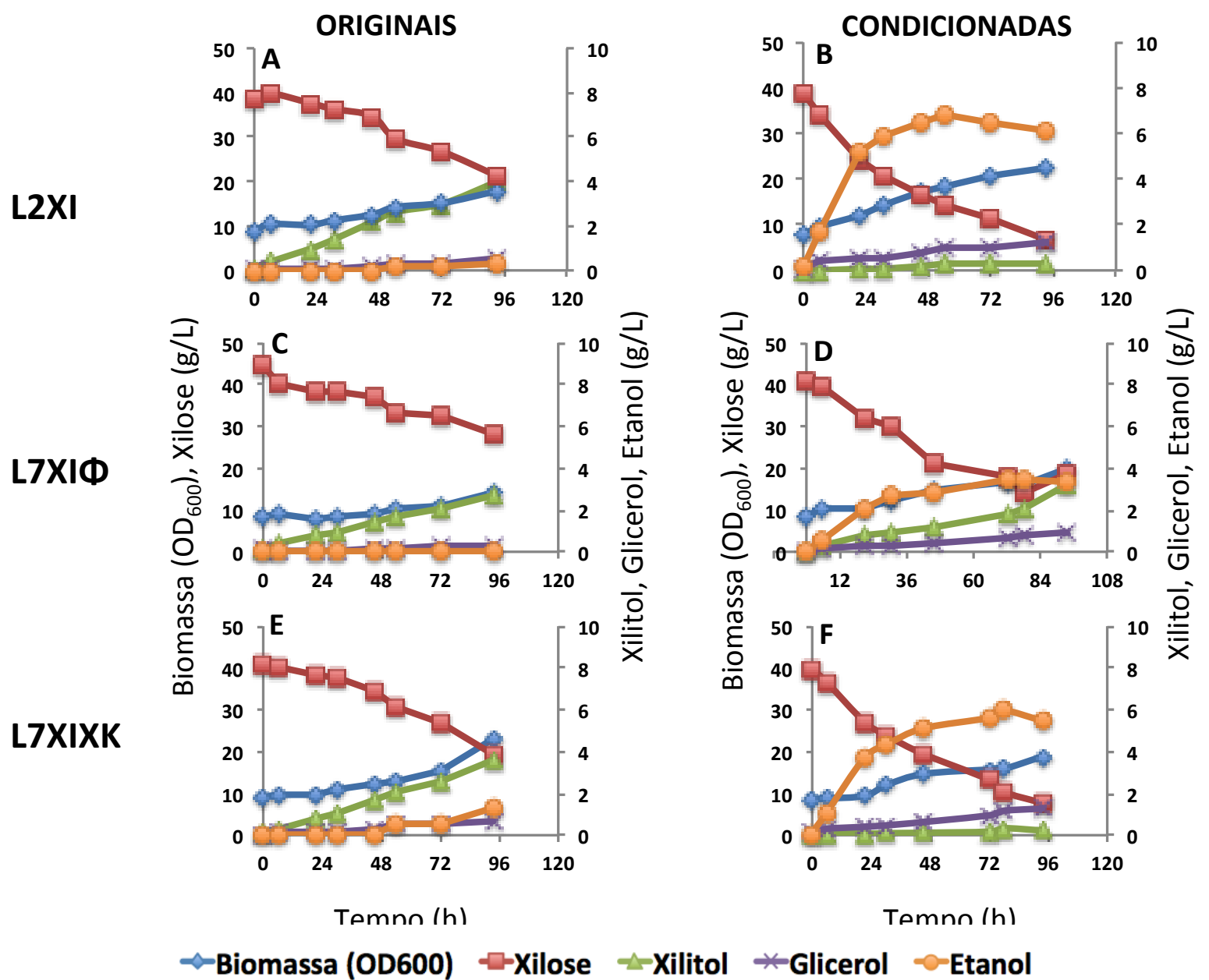

Figura 12: Teste de crescimento com inóculo inicial alto das linhagens transformantes Originais (A, C, E) e Condicionadas (B, D, G). Consumo de xilose (vermelho), e formação de biomassa (azul), xilitol (verde), etanol (laranja) e glicerol (roxo), durante fermentação aeróbica das linhagens L2XI Original e Condicionada (A, B) L7XIФ Original e Condicionada (C, D), e L7XIXK Original e Condicionada (E, F). Não houve produção de ácido acético em nenhuma das linhagens. Cada gráfico é um exemplo representativo de fermentação aeróbica, 96 horas, com OD $_{600}$ inicial igual a 10,feito em duplicata.

Uma vez tendo começado com a densidade celular maior, não há tanto crescimento celular, e o grande número de células utilizam a xilose e produzem metabólitos mais rapidamente. 
Um dos principais produtos das linhagens condicionadas foi o etanol. Enquanto para L2XI e L7XIXK a quantidade final de etanol produzida foi de 4,40 \pm $1,4 \mathrm{~g} / \mathrm{L}$ e $6,05 \pm 0,12 \mathrm{~g} / \mathrm{L}$ e o rendimento igual a $0,19 \pm 0,01 \mathrm{~g} / \mathrm{g}$ e $0,15 \pm 0,03 \mathrm{~g} / \mathrm{g}$ respectivamente, a linhagem L7XIФ teve o menor rendimento $(0,016 \pm 0,023 \mathrm{~g} / \mathrm{g}) \mathrm{e}$ concentração final de etanol $(0,37 \pm 0,052 \mathrm{~g} / \mathrm{L})$. Entretanto, novamente a quantidade de xilitol produzida foi maior que todas as linhagens $(3,62 \pm 0,62 \mathrm{~g} / \mathrm{L})$ e o rendimento comparável ao das linhagens originais.

As linhagens originais tiveram rendimento mínimo de etanol, chegando ao máximo de 0,03 $\pm 0,04 \mathrm{~g} / \mathrm{g}$ na linhagem L7XIXK. Os rendimentos de glicerol aumentaram para todas as linhagens condicionadas, entre duas (L7XIXK) e sete vezes (L7XIФ).Os dados referentes à concentração final de produto, produtividade, consumo de substrato e rendimento das leveduras transformantes, no crescimento de alta densidade celular estão resumidos nas Tabelas 8, 9 e 10 .

Visando uma análise mais minuciosa das linhagens L2XI original e condicionadas, foram realizadas fermentações anaeróbicas em biorreator (Figura 13). Também para avaliar o efeito da cofermentação, a levedura dispôs tanto de glicose $(20 \mathrm{~g} / \mathrm{L})$ quanto de xilose $(40 \mathrm{~g} / \mathrm{L})$ como fontes de carbono.

Era esperado que o investimento da levedura em anaerobiose fosse menos voltado para crescimento, e houvesse maior produção de metabólitos secundários. De fato, isto foi observado na fermentação feita no biorreator. Como observado, ambas as linhagens apresentaram capacidades idênticas de metabolizar glicose, resultando em concentrações de biomassa semelhantes. As duas linhagens consumiram completamente a glicose. A linhagem original consumiu 3,62 $\pm 2,27 \mathrm{~g} / \mathrm{L}$ xilose, enquanto a linhagem condicionada consumiu 7,04 \pm 1,07 g/L deste açúcar (Figura 13 e Tabela 11), o que resultou no aumento da produção de etanol de 6,98 \pm 0,41 para $9,58 \pm 0,09$. Também observou que a produção de xilitol diminui $72 \%$ quando comparado com a linhagem original. Desta forma, enquanto o rendimento de etanol aumentou a de xilitol diminuiu. (Figura 13 e Tabela 13).

Para ambas as linhagens, foram produzidas aproximadamente 6,6 g/L de etanol a partir da glicose. O rendimento de glicerol aumentou apenas 0,29 vezes. Para ambas as linhagens, os rendimentos de ácido acético permaneceram próximos $(0,038$ 
g/g e 0,048 g/g), entretanto, a concentração final de ácido acético produzida pela linhagem condicionada foi $40 \%$ maior.

As Tabelas 11, 12 e 13 resumem os valores de rendimento, produtividade específica, taxa de crescimento, taxa de consumo de substrato e balanço de carbono das fermentações feitas no biorreator. 
Tabela 8: Concentração final de xilose consumida e produtos formados, em fermentação em xilose com alta OD600 inicial.

\begin{tabular}{|c|c|c|c|c|c|c|c|c|c|c|c|c|}
\hline \multirow{2}{*}{ Linhagem } & \multicolumn{2}{|c|}{ Xilose consumida $\mathrm{g} / \mathrm{L}$} & \multicolumn{2}{|c|}{ Etanol g/L } & \multicolumn{2}{|c|}{ Acetato g/L } & \multicolumn{2}{|c|}{ Glicerol g/L } & \multicolumn{2}{|c|}{ Xilitol $\mathrm{g} / \mathrm{L}$} & \multicolumn{2}{|c|}{ Biomassa $\mathrm{g} / \mathrm{L}$} \\
\hline & Média & Desv Pad & Média & Desv Pad & Média & Desv Pad & Média & Desv Pad & Média & Desv Pad & Média & Desv Pad \\
\hline L2XI Original & 15,38 & 2,95 & 0,17 & 0,24 & 0,00 & 0,00 & 0,26 & 0,37 & 3,87 & 0,03 & 3,44 & 1,34 \\
\hline L2XI Condicionado & 31,41 & 0,98 & 6,05 & 0,12 & 0,01 & 0,01 & 1,19 & 0,10 & 0,34 & 0,00 & 10,48 & 4,84 \\
\hline L7XIФ Original & 11,17 & 7,18 & 0,00 & 0,00 & 0,00 & 0,00 & 0,11 & 0,16 & 2,86 & 0,41 & 1,46 & 1,66 \\
\hline L7XIФ Condicionada & 21,37 & 1,65 & 0,37 & 0,52 & 0,00 & 0,00 & 0,79 & 0,11 & 3,62 & 0,62 & 4,81 & 0,97 \\
\hline L7XIXK Original & 18,50 & 4,20 & 0,66 & 0,94 & 0,05 & 0,02 & 0,58 & 0,03 & 3,42 & 0,10 & 5,11 & 2,20 \\
\hline L7XIXK Condicionada & 30,03 & 2,83 & 4,40 & 1,40 & 0,00 & 0,00 & 1,21 & 0,04 & 0,19 & 0,04 & 4,81 & 0,09 \\
\hline
\end{tabular}

Médias referentes a duplicatas biológicas. "Desv Pad” é referente a desvio padrão.

Tabela 9: Rendimento em gramas de produto formado por grama de substrato (xilose) consumido em fermentação aeróbia de alta OD600 inicial.

\begin{tabular}{|l|c|c|c|c|c|c|c|c|}
\hline \multirow{2}{*}{ Linhagem } & \multicolumn{9}{|c|}{ Rendimento $\left(\mathrm{g} . \mathrm{g}^{-1}\right)$} \\
\cline { 2 - 9 } & \multicolumn{2}{|c|}{ Etanol } & \multicolumn{2}{c|}{ Glicerol } & \multicolumn{3}{c|}{ Xilitol } & \multicolumn{2}{c|}{ Biomassa } \\
\cline { 2 - 9 } & Média & Desv Pad & Média & Desv Pad & Média & Desv Pad & Média & Desv Pad \\
\hline L2XI Original & 0,010 & 0,014 & 0,015 & 0,021 & 0,256 & 0,047 & 0,219 & 0,045 \\
\hline L2XI Condicionado & 0,193 & 0,010 & 0,038 & 0,004 & 0,011 & 0,000 & 0,336 & 0,165 \\
\hline L7XIФ Original & 0,000 & 0,000 & 0,007 & 0,010 & 0,338 & 0,254 & 0,105 & 0,081 \\
\hline L7XIФ Condicionada & 0,016 & 0,023 & 0,037 & 0,002 & 0,171 & 0,042 & 0,224 & 0,028 \\
\hline L7XIXK Original & 0,031 & 0,044 & 0,032 & 0,005 & 0,189 & 0,038 & 0,270 & 0,058 \\
\hline L7XIXK Condicionada & 0,145 & 0,033 & 0,040 & 0,005 & 0,006 & 0,001 & 0,161 & 0,012 \\
\hline
\end{tabular}

*O rendimento de ácido acético não foi mensurável.

Médias referentes a duplicatas biológicas. "Desv Pad" é referente a desvio padrão. 
Tabela 10: Produtividade específica de produto em fermentação de xilose com alta OD600 inicial.

\begin{tabular}{|c|c|c|c|c|c|c|c|c|}
\hline \multirow{3}{*}{ Linhagem } & \multirow{2}{*}{\multicolumn{2}{|c|}{$\begin{array}{c}\text { Taxa de consumo específico } \\
\text { de xilose } \\
\left(\mathrm{g} \cdot \mathrm{g}^{-1} \cdot \mathrm{h}^{-1}\right)\end{array}$}} & \multicolumn{6}{|c|}{ Produtividade $\left(\mathrm{g} \cdot \mathrm{g}^{-1} \cdot \mathrm{h}^{-1}\right)$} \\
\hline & & & \multicolumn{2}{|c|}{ Etanol } & \multicolumn{2}{|c|}{ Glicerol } & \multicolumn{2}{|c|}{ Xilitol } \\
\hline & Média & Desv Pad & Média & Desv Pad & Média & Desv Pad & Média & Desv Pad \\
\hline L2XI Original & 0,050 & 0,011 & 0,000 & 0,001 & 0,001 & 0,001 & 0,013 & 0,005 \\
\hline L2XI Condicionada & 0,036 & 0,017 & 0,007 & 0,003 & 0,001 & 0,001 & 0,000 & 0,000 \\
\hline L7XI0 Original & 0,148 & 0,116 & 0,000 & 0,000 & 0,000 & 0,001 & 0,065 & 0,077 \\
\hline L7XIФ Condicionada & 0,049 & 0,007 & 0,001 & 0,001 & 0,002 & 0,000 & 0,008 & 0,003 \\
\hline L7XIXK Original & 0,041 & 0,009 & 0,001 & 0,002 & 0,001 & 0,001 & 0,008 & 0,003 \\
\hline L7XIXK Condicionada & 0,067 & 0,004 & 0,010 & 0,003 & 0,003 & 0,000 & 0,000 & 0,000 \\
\hline
\end{tabular}

* A produtividade de ácido acético não foi mensurável

Médias referentes a duplicatas biológicas. "Desv Pad" é referente a desvio padrão. 
L2XI

Original

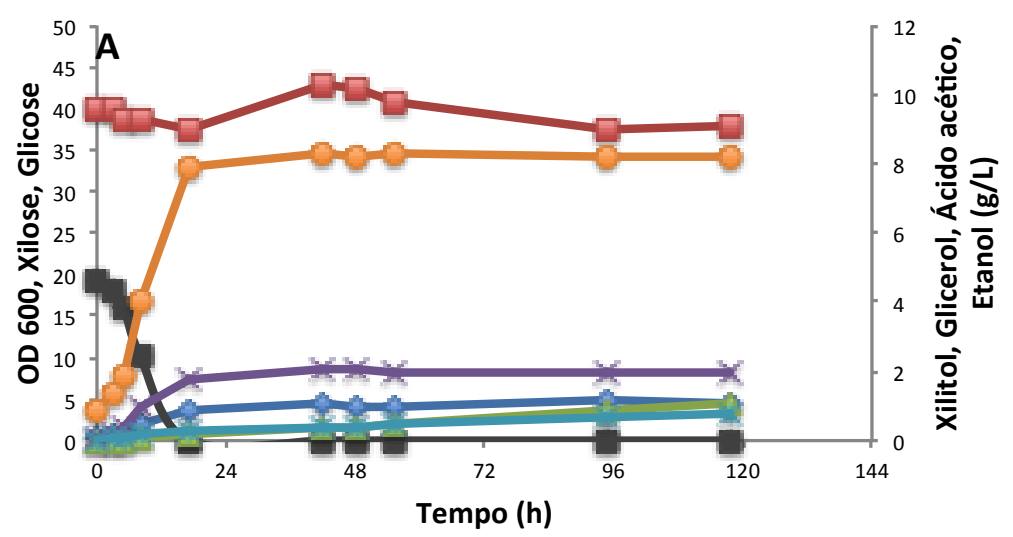

L2XI

Condicionada

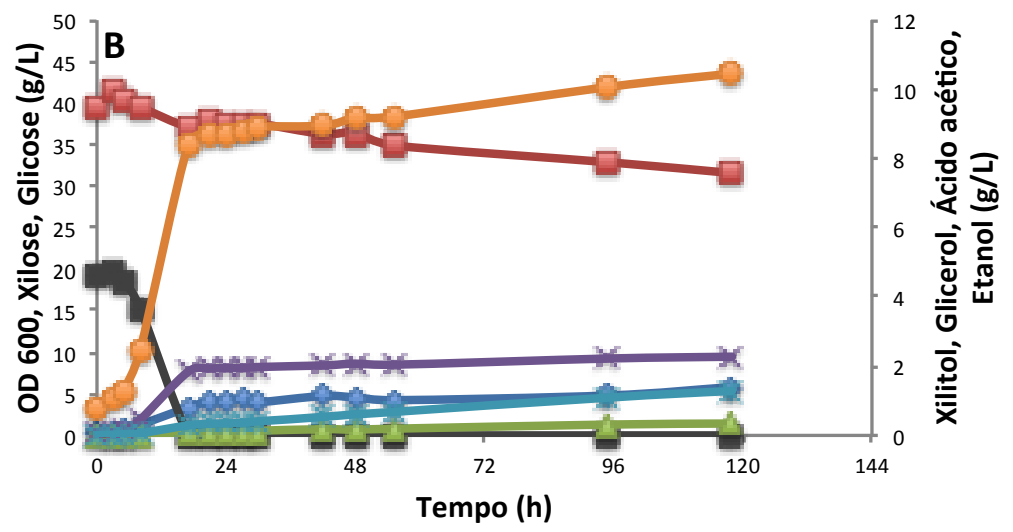

- Glicose $\approx$ Biomassa (OD600) $\square$-Xilose $\triangle$ Xilitol *Glicerol *AcAcet $\approx$ Etanol

Figura 13: Cofermentação de glicose e xilose pelas linhagens L2XI Original e Condicionada (A, B) em biorreator em anaerobiose. Consumo de glicose (preto) e xilose (vermelho), formação de biomassa (azul), glicerol (roxo), ácido acético (turquesa), xilitol (verde) e etanol (laranja) durante fermentação anaeróbica em biorreator. Cada gráfico é um exemplo representativo de uma fermentação anaeróbica $(900 \mathrm{~mL}$ de solução de sais + Xilose $40 \mathrm{~g} / \mathrm{L}$ + Glicose 20g/L) em reator de 1 L, OD feito em duplicata. 
Tabela 11: Concentração final de açúcares consumidos e produtos formados por cofermentação em biorreator.

\begin{tabular}{|c|c|c|c|c|c|c|c|c|c|c|c|c|c|c|}
\hline \multirow{2}{*}{ Linhagem } & \multicolumn{2}{|c|}{$\begin{array}{c}\text { Glicose } \\
\text { consumida }\end{array}$} & \multicolumn{2}{|c|}{$\begin{array}{c}\text { Xilose } \\
\text { consumida } \mathrm{g} / \mathrm{L}\end{array}$} & \multicolumn{2}{|c|}{ Etanol g/L } & \multicolumn{2}{|c|}{ Acetato g/L } & \multicolumn{2}{|c|}{ Glicerol g/L } & \multicolumn{2}{|c|}{ Xilitol g/L } & \multicolumn{2}{|c|}{ Biomassa $\mathrm{g} / \mathrm{L}$} \\
\hline & Média & $\begin{array}{c}\text { Desv } \\
\text { Pad }\end{array}$ & Média & $\begin{array}{c}\text { Desv } \\
\text { Pad }\end{array}$ & Média & $\begin{array}{c}\text { Desv } \\
\text { Pad }\end{array}$ & Média & $\begin{array}{c}\text { Desv } \\
\text { Pad }\end{array}$ & Média & $\begin{array}{c}\text { Desv } \\
\text { Pad }\end{array}$ & Média & $\begin{array}{c}\text { Desv } \\
\text { Pad }\end{array}$ & Média & $\begin{array}{c}\text { Desv } \\
\text { Pad }\end{array}$ \\
\hline L2XI Original & 19,76 & 0,65 & 3,62 & 2,27 & 6,98 & 0,41 & 0,90 & 0,21 & 1,75 & 0,26 & 1,21 & 0,13 & 1,98 & 0,02 \\
\hline
\end{tabular}

Médias referentes a duplicatas biológicas. "Desv Pad" é referente a desvio padrão.

Tabela 12: Taxa de crescimento, balanço de carbono e rendimento em gramas de produto formado por grama de açúcar consumido de cofermentação em biorreator.

\begin{tabular}{|c|c|c|c|c|c|c|c|c|c|c|c|c|c|c|c|c|}
\hline \multirow[b]{3}{*}{ Linhagem } & \multicolumn{4}{|c|}{ Taxa de crescimento $\left(\mathrm{h}^{-1}\right)$} & \multicolumn{10}{|c|}{ Rendimento (g. $\mathrm{g}^{-1}$ ) } & \multirow{2}{*}{\multicolumn{2}{|c|}{$\begin{array}{l}\text { Balanço de } \\
\text { carbono }\end{array}$}} \\
\hline & \multicolumn{2}{|c|}{ Glicose } & \multicolumn{2}{|c|}{ Xilose } & \multicolumn{2}{|c|}{ Etanol } & \multicolumn{2}{|c|}{ Ácido Acético } & \multicolumn{2}{|c|}{ Glicerol } & \multicolumn{2}{|c|}{ Xilitol } & \multicolumn{2}{|c|}{ Biomassa } & & \\
\hline & Média & $\begin{array}{l}\text { Desv } \\
\text { Pad }\end{array}$ & Média & $\begin{array}{l}\text { Desv } \\
\text { Pad }\end{array}$ & Média & $\begin{array}{c}\text { Desv } \\
\text { Pad }\end{array}$ & Média & $\begin{array}{l}\text { Desv } \\
\text { Pad }\end{array}$ & Média & $\begin{array}{l}\text { Desv } \\
\text { Pad }\end{array}$ & Média & $\begin{array}{l}\text { Desv } \\
\text { Pad }\end{array}$ & Média & $\begin{array}{l}\text { Desv } \\
\text { Pad }\end{array}$ & Média & $\%$ \\
\hline L2XI Original & 0,145 & 0,039 & 0,002 & 0,000 & 0,302 & 0,055 & 0,038 & 0,004 & 0,076 & 0,021 & 0,052 & 0,001 & 0,086 & 0,011 & 0,860 & 85,99 \\
\hline $\begin{array}{l}\text { L2XI } \\
\text { Condicionado }\end{array}$ & 0,148 & 0,048 & 0,003 & 0,000 & 0,361 & 0,008 & 0,048 & 0,000 & 0,086 & 0,006 & 0,013 & 0,000 & 0,094 & 0,000 & 0,965 & 96,54 \\
\hline
\end{tabular}

Médias referentes a duplicatas biológicas. "Desv Pad" é referente a desvio padrão.

Tabela 13: Produtividade específica de produtos formados por cofermentação em biorreator.

\begin{tabular}{|c|c|c|c|c|c|c|c|c|c|c|c|c|}
\hline \multirow[b]{3}{*}{ Linhagem } & \multirow{2}{*}{\multicolumn{2}{|c|}{$\begin{array}{c}\text { Taxa de consumo } \\
\text { específico de glicose } \\
\left(\mathrm{g} \cdot \mathrm{g}^{-1} \cdot \mathrm{h}^{-1}\right)\end{array}$}} & \multirow{2}{*}{\multicolumn{2}{|c|}{$\begin{array}{l}\text { Taxa de consumo } \\
\text { específico de xilose } \\
\left(\mathrm{g} \cdot \mathrm{g}^{-1} \cdot \mathrm{h}^{-1}\right)\end{array}$}} & \multicolumn{8}{|c|}{ Produtividade $\left(\mathrm{g} \cdot \mathrm{g}^{-1} \cdot \mathrm{h}^{-1}\right)$} \\
\hline & & & & & \multicolumn{2}{|c|}{ Etanol } & \multicolumn{2}{|c|}{ Ácido Acético } & \multicolumn{2}{|c|}{ Glicerol } & \multicolumn{2}{|c|}{ Xilitol } \\
\hline & Média & $\begin{array}{c}\text { Desv } \\
\text { Pad } \\
\end{array}$ & Média & $\begin{array}{l}\text { Desv } \\
\text { Pad }\end{array}$ & Média & $\begin{array}{c}\text { Desv } \\
\text { Pad }\end{array}$ & Média & $\begin{array}{c}\text { Desv } \\
\text { Pad }\end{array}$ & Média & $\begin{array}{c}\text { Desv } \\
\text { Pad }\end{array}$ & Média & $\begin{array}{c}\text { Desv } \\
\text { Pad }\end{array}$ \\
\hline L2XI Original & 0,089 & 0,010 & 0,017 & 0,012 & 0,031 & 0,001 & 0,004 & 0,001 & 0,008 & 0,001 & 0,005 & 0,001 \\
\hline L2XI Condicionado & 0,070 & 0,008 & 0,025 & 0,001 & 0,034 & 0,003 & 0,005 & 0,000 & 0,008 & 0,001 & 0,001 & 0,000 \\
\hline
\end{tabular}

Médias referentes a duplicatas biológicas. "Desv Pad" é referente a desvio padrão. 


\subsection{Teste de atividade enzimática}

A atividade da xiluloquinase é fundamental no metabolismo da xilose uma vez que permitiriam a entrada da xilulose fosforilada na via da pentose fosfato. Os níveis da atividade enzimática de XK foram determinados, utilizando extrato celular das três linhagens originais, e três condicionadas (Figura 14).

Os resultados demonstram que todas as seis linhagens apresentaram atividade específica em torno de $30 \mathrm{U} / \mathrm{mg}$, com exceção da linhagem L2XI original que apresentou atividade cerca de duas vezes maior (Figura 14). O teste estatístico confirmou que a única amostra com diferença significativa, foi a linhagem L2XI, quando comparada com sua respectiva condicionada ou outras linhagens. As outras linhagens não tiveram diferenças significativas na atividade enzimática entre si.

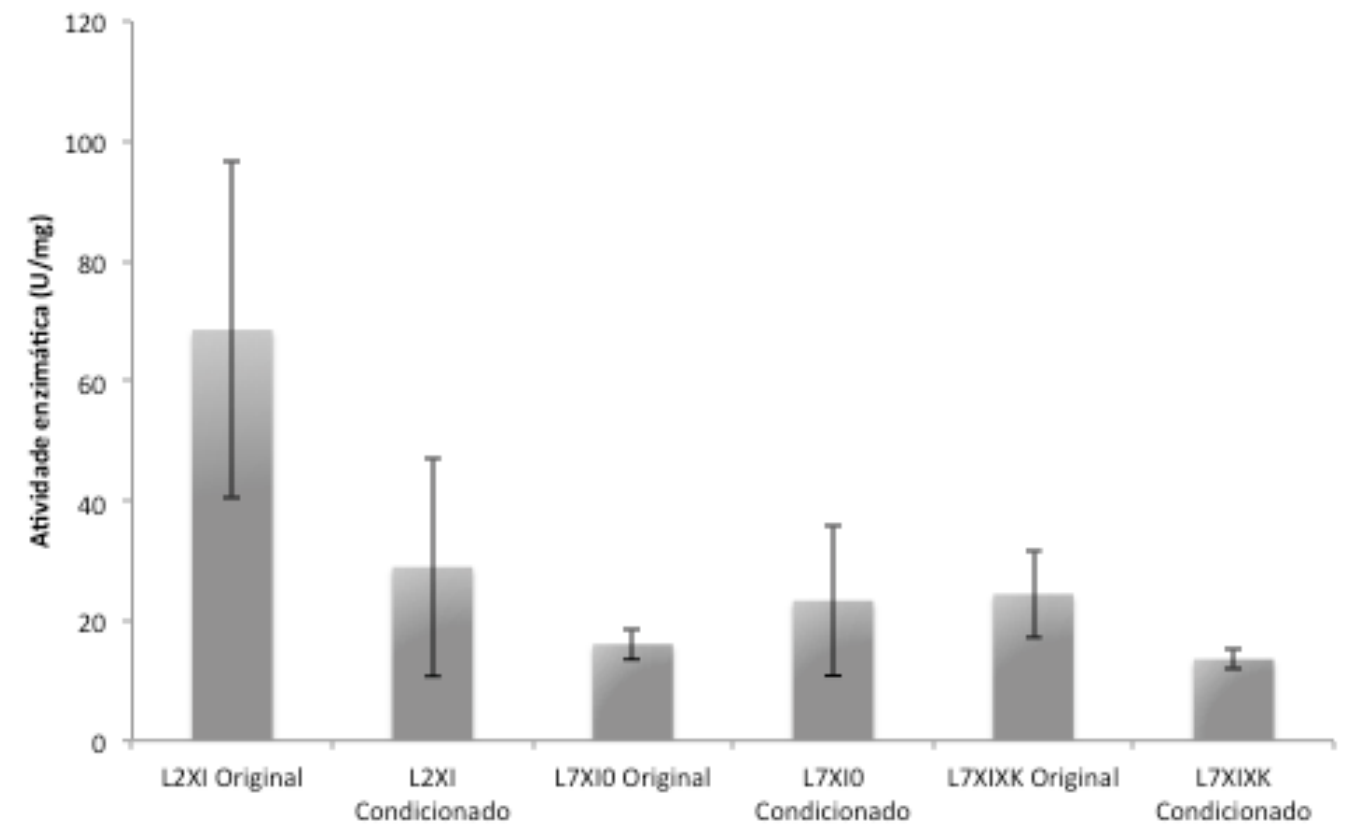

Figura 14: Atividade enzimática de xiluloquinase das linhagens transformantes Originais e Condicionadas. As barras indicam o desvio padrão das amostras. A unidade de atividade enzimática é definida como a quantidade de enzimas necessária para converter um micromol de $\mathrm{NADH}$ à $\mathrm{NAD}+$ no intervalo de tempo de dez minutos. A unidade internacional de atividade enzimática (U) representa a atividade específica da enzima. 


\section{Sequenciamento da XIPiro Condicionada}

\subsection{Preparação de amostras para sequenciamento}

Afim de investigar possíveis mutações que possam ter ocorrido na XI transformada durante o processo de condicionamento, as amostras foram sequenciadas através da metodologia Sanger (SANGER; COULSON, 1975). Para tanto, os plasmídeos das linhagens L7XIФ e L7XIXK foram extraídos de levedura, e transformados por eletroporação em E. coli HB101. Seis colônias (A; B; C; D; E; F) foram selecionadas de cada uma das placas da transformação. Para confirmar a presença do gene de XI nas colônias escolhidas, foi feita uma PCR com par de oligonucleotídeos 11/12 (Tabela 3) para amplificação de XI, utilizando o plasmídeo das colônias de bactéria transformada com plasmídeo extraído de levedura como molde (Figura 15).

O plasmídeo extraído da L2XI condicionada não foi transformado com sucesso em E. coli, portanto, foi feita uma PCR para amplificação do gene de XI utilizando o plasmídeo extraído da levedura condicionada como molde.

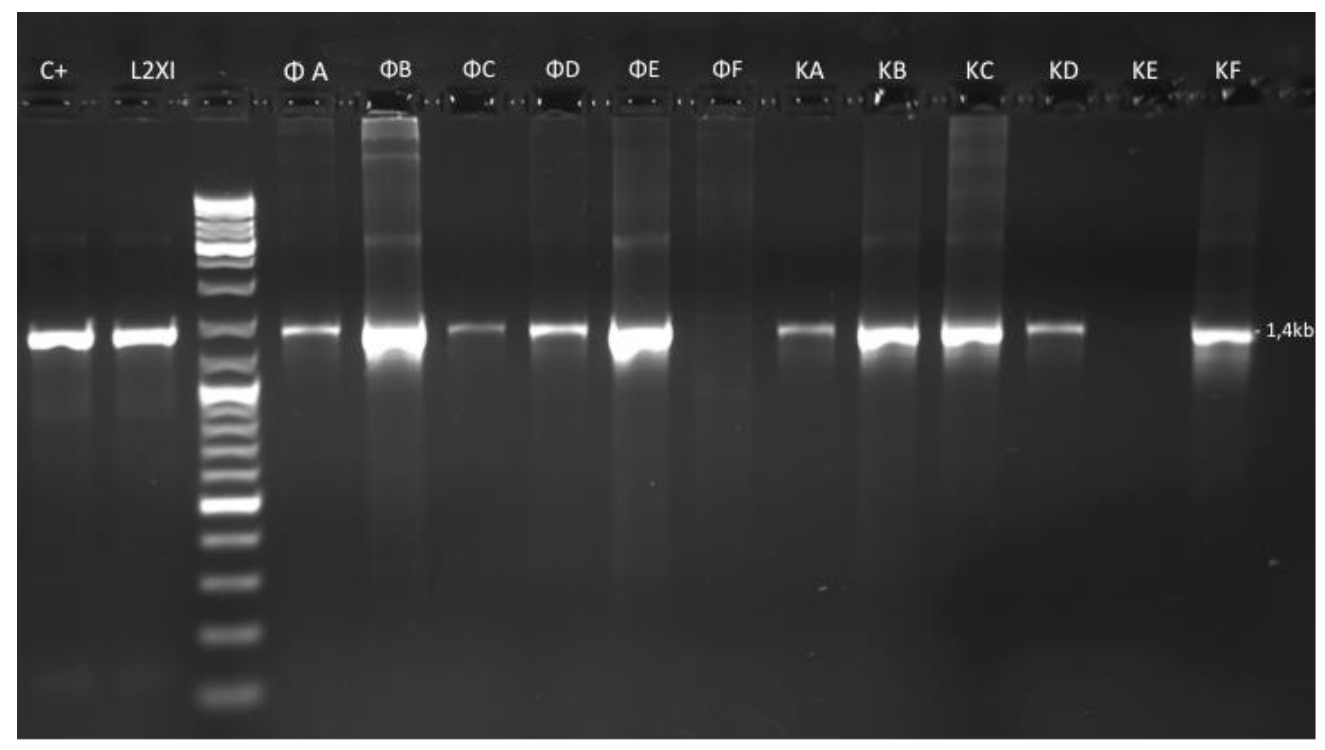

Figura 15: PCR de confirmação da presença do gene XIPiro das colônias de bactéria transformada com DNA extraído das leveduras. Análise eletroforética em gel de agarose. L7XIФ (ФA; ФB; ФC; ФD; ФE; ФF) e L7XIXK (KA; KB; KC; KD; KE; KF). A 
banda L2XI é referente à PCR feita a partir da minipreparação de DNA da levedura L2XI. A banda $\mathrm{C}+$ é referente à amplificação do gene XI do plasmídeo p424-XI originalmente construído. Marcador de massa molecular Gene Ruler DNA Ladder Mix (Thermo).

A PCR dos plasmídeos indicou presença dos gene XIPiro nas colônias A, B, C, D e E na levedura L7XIФ e nas colônias A, B, C, D, e F na levedura L7XIXK (Figura 15). As amostras positivas para o gene foram purificadas e enviadas para sequenciamento.

A PCR de L2XI indicou a presença do gene no plasmídeo extraído da levedura. Foi então realizada uma PCR com a enzima $P f u$, utilizando o mesmo DNA extraído da levedura como molde, que foi purificada e enviada para sequenciamento.

E também foi enviada, a amostra do plasmídeo p424-XI originalmente construído e utilizado para a transformação das leveduras laboratoriais.

\subsection{Sequenciamento das amostras}

$\mathrm{O}$ alinhamento das sequências de XI das leveduras condicionadas e o plasmídeo original p424-XI como controle, analisadas no programa Geneious 8.1, mostrada na Figura 16, não indicaram nenhuma diferença entre as amostras L2XI, L7XIФ e L7XIXK quando comparadas com a sequência do plasmídeo original (p424-XI controle). As sequências completas e a montagem dos contigs se encontra no anexo 1 .

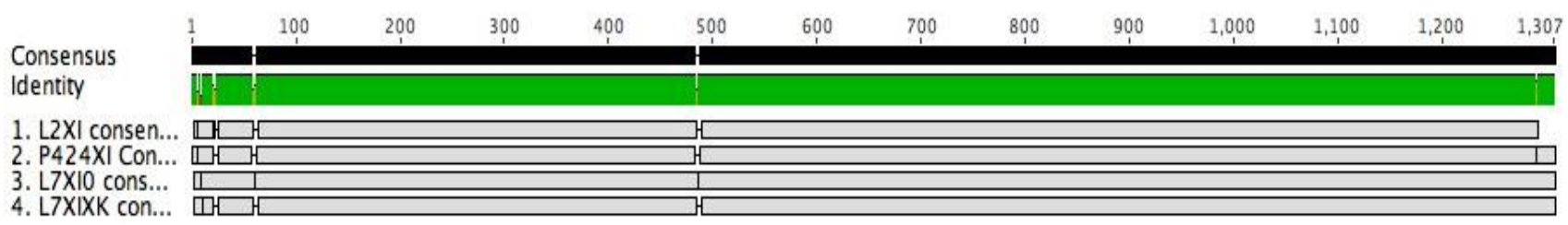

Figura 16: Alinhamento entre as sequencias de XIPiro das leveduras condicionadas L2XI, L7XIФ, L7XIXK. 


\section{Investigacão da melhoria das linhagens condicionadas e geracão de linhagens de seleção}

\subsection{Obtenção de linhagens curadas}

O condicionamento gerou linhagens com melhor capacidade de fermentar xilose aerobicamente que as originalmente obtidas sem condicionamento (Figuras 7, 11 e 12 ). A melhor capacidade fermentativa pode ser resultado de mudanças no genoma da levedura ou a mudanças relacionadas ao número de cópias dos plasmídeos ou mutações nos genes inseridos nos mesmos. Foi então iniciado um processo de cura das leveduras como estratégia para investigar os possíveis motivadores desta diferença observada.

A cura consiste na retirada dos plasmídeos do citoplasma das leveduras transformantes, através de sucessivos cultivos destas linhagens em meio não seletivo. Na eventualidade de obtermos uma linhagem curada, esta pode ser aplicada como linhagem de seleção.

Linhagens de seleção são linhagens modelo que se destacam como ideais para pesquisa de prospecção de novos genes. No caso, as linhagens curadas se tornariam ideais para pesquisas para expressão de novos possíveis genes codificadores de xilose isomerase, uma vez que as linhagens condicionadas reduzem seu tempo de fase lag, quando comparadas com as linhagens de CEN.PK originais, e os resultados podem ser obtidos com maior rapidez.

Neste trabalho as três linhagens condicionadas, as quais possuem plasmídeos epissomais com marcas de seleção auxotróficas, foram cultivadas, em ciclos sucessivos, em meio não seletivo (YPD) suplementado com Triptofano. Após dez ciclos de cultivo em meio rico suplementado para L7XIXK e vinte ciclos de cultivo para L2XI e L7XIФ foi feito um teste de cura, em que 52 colônias do cultivo isolado em placa foram repicadas em meio YG20 ágar (meio mínimo), e YPD ágar (meio completo). A Figura 17 mostra o resultado do teste de cura, em que é possível visualizar as colônias condicionadas curadas, crescidas em YPD, mas sem crescimento aparente em YG20. 

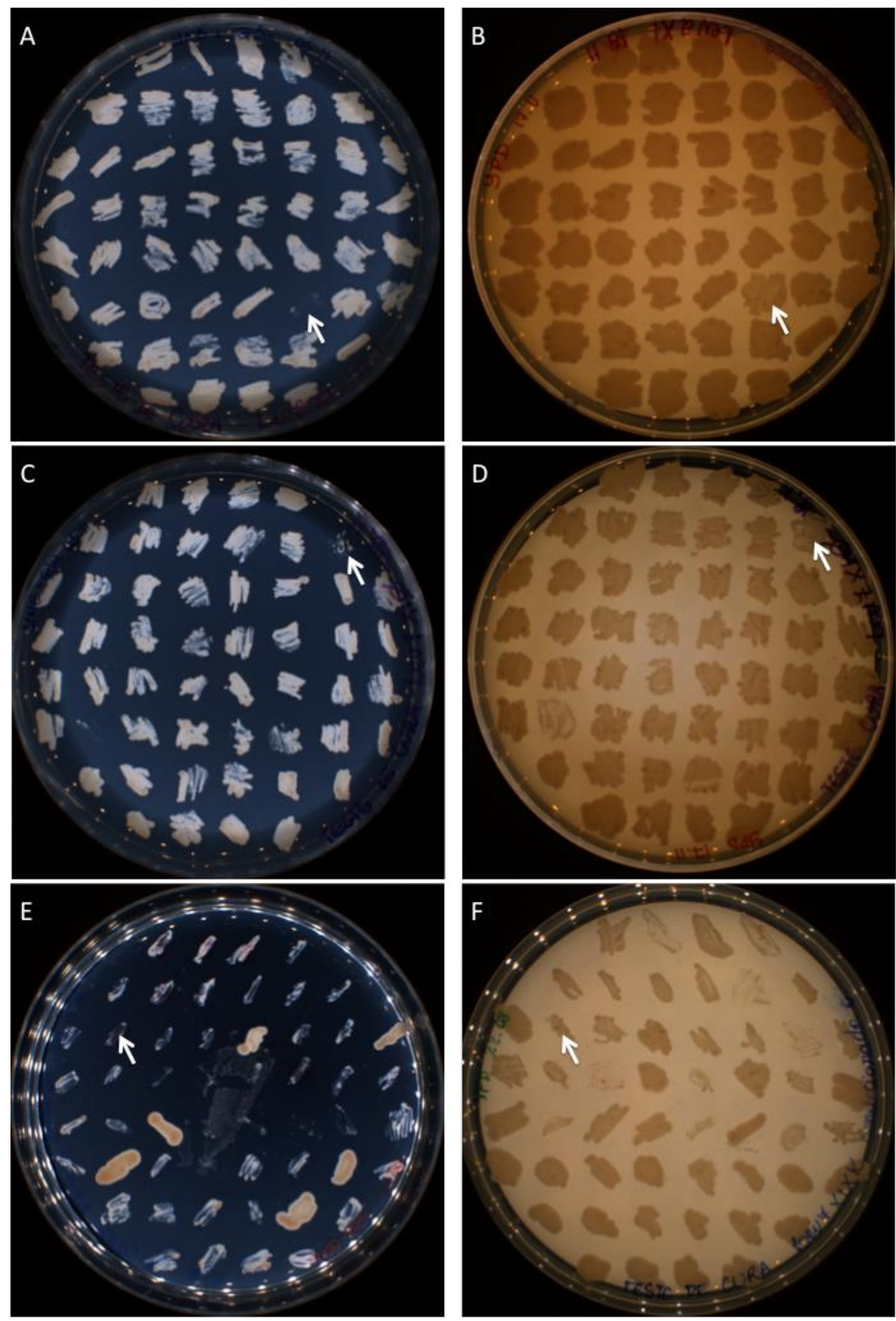

Figura 17: Teste de crescimento das leveduras condicionadas curadas L2XI (A; B) L7XIФ (C; D) e L7XIXK (E; F) em meio YG20 (A; C; E) e YPD (B; D; F). As setas brancas apontam as colônias escolhidas como curadas. 
Ao final, foi escolhida uma colônia com crescimento positivo em YPD e negativo em YNB, para cada uma das três linhagens de leveduras condicionadas, sendo elas LC2 (L2XI colônia curada \#37) LC7Ф (L7XIФ colônia curada \#9) e LC7 (L7XIXK colônia curada \#12).

\subsection{Confirmação da cura por teste fisiológico e PCR}

As colônias selecionadas foram plaqueadas novamente em meio YG20 ágar para uma segunda confirmação de que não haveria crescimento em meio mínimo. Após 72 horas de incubação, nenhuma das leveduras selecionadas apresentaram crescimento.

Também foi realizado um teste fisiológico da cura (Figura 18), em que as colônias escolhidas foram inoculadas em YPX, YG20 e YX40, para confirmar a cura em meio mínimo, seja ele suplementado com glicose ou xilose, e em meio rico, se a única fonte de carbono disponível for xilose. Como controle, foram inoculadas nos mesmos meios as leveduras condicionadas L2XI, L7XIФ e L7XIXK. O resultado do teste fisiológico indicou crescimento das três linhagens curadas em YPX, porém, pouco menor que o crescimento das condicionadas (Figura 17). Em meio YX40, nenhuma das três linhagens curadas cresceu, enquanto as três condicionadas apresentaram crescimento. Em meio YG20, a levedura curada LC2 apresentou crescimento, ainda que significantemente menor que as condicionadas e LC $\Phi$ teve um lento início de crescimento após 72h, enquanto a LC7 não apresentou nenhum crescimento.

O crescimento nos meios seletivos das linhagens LC2 e LC $\Phi$ indicam que estas não perderam os plasmídeos ou os genes, uma vez que a perda do plasmídeo impossibilitaria o crescimento em meio mínimo (YNB) e a perda do gene XIPiro impossibilitaria crescimento em meios cuja a única fonte de carbono é xilose. Entretanto, para a LC7, houve crescimento em YPX, ou seja, meio rico com xilose como fonte de carbono, enquanto não houve crescimento em nenhum dos dois meios mínimos. 


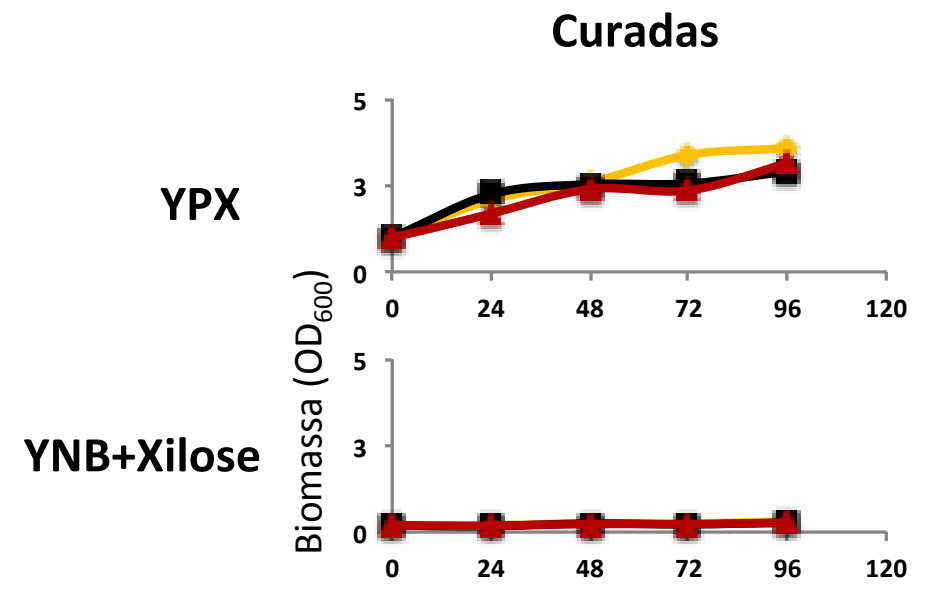

YNB+Glicose

\section{Curadas}

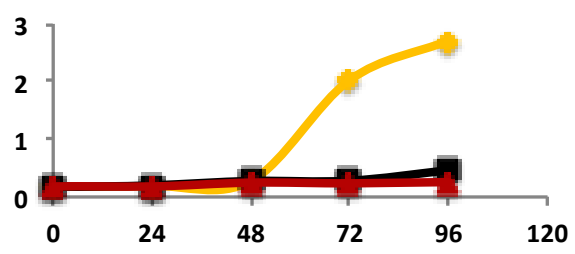

Condicionadas
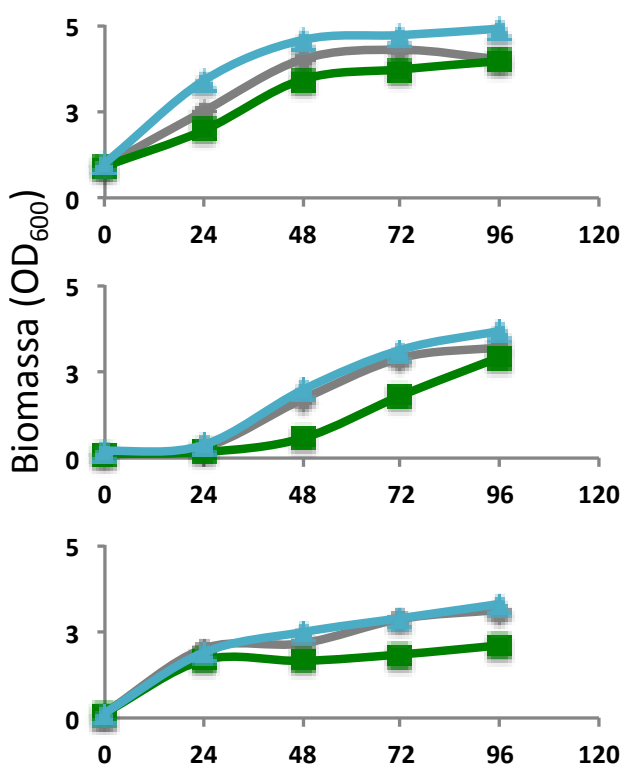

Tempo (h)

$\rightarrow$ CURA $2 \rightarrow$ CURA $\Phi \rightarrow$ CURA $7 \rightarrow$ L2XI $\rightarrow$ L7XI $\rightarrow$ L7XIXK

Figura 18: Avaliação do crescimento das leveduras curadas, em diferentes meios YPX (A ; B), YX40 (B; C) e YG20 (D; E) para as leveduras curadas LC2 (amarelo), LC $\Phi$ (preto), LC7 (vermelho) e as Condicionadas como controle L2XI (cinza), L7XIФ (verde) e L7XIXK (azul). Cada gráfico é um exemplo representativo de um teste feito em duplicata (em tubo de $50 \mathrm{~mL}$ contendo $5 \mathrm{~mL}$ de meio, OD $_{600}$ inicial $=0,2$ ) por 96 horas. A escala de $\mathrm{E}$ difere dos demais gráficos a fim de evidenciar o crescimento das leveduras.

Uma vez que havia a suspeita da presença do gene nas linhagens submetidas a cura, inclusive LC7 que não cresceu em YNB, foi feita PCR de colônia das três linhagens, utilizando oligonucleotídeos 11/12 (Tabela 3) para amplificação de XI (Figura 19). 


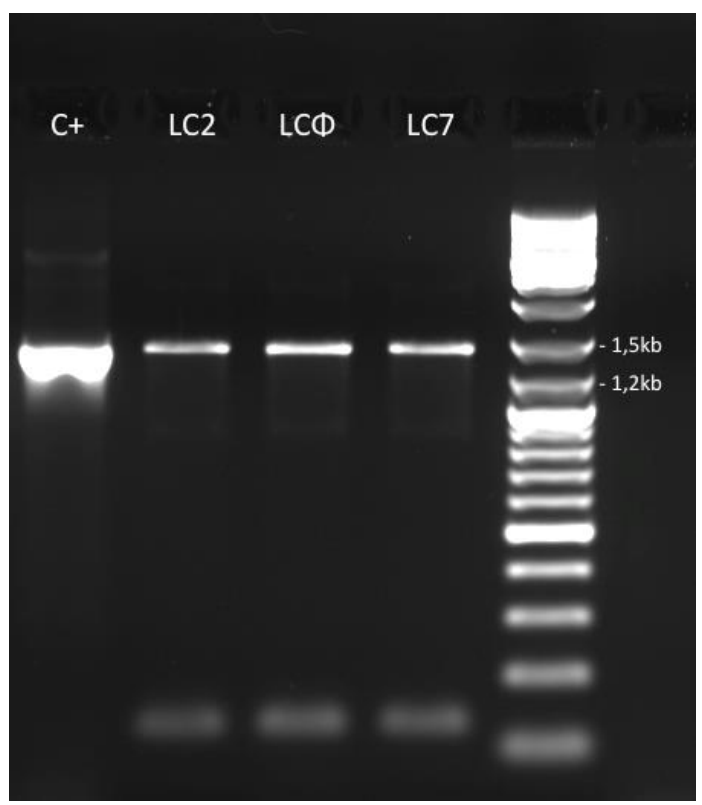

Figura 19: PCR de colônia das leveduras curadas LC2, LCФ e L7XIXK. Análise eletroforética em gel de agarose 1\%. O controle da PCR $(\mathrm{C}+)$ foi feito utilizando plasmídeo p424-XIPiro como molde. Marcador de massa molecular Gene Ruler DNA Ladder Mix (Thermo).

Todas as linhagens apresentaram banda de aproximadamente $1,4 \mathrm{~kb}$ na PCR de colônia, indicando ainda a presença do gene XIPiro ainda nas leveduras. O crescimento das linhagens LC2 e LCФ em meio seletivo, indica que não houve perda dos plasmídeos do citoplasma, o que é compatível com a presença do gene na PCR. Entretanto, para a linhagem LC7, em que a levedura não cresceu em meio seletivo, indicando a perda dos plasmídeos, a presença do gene pode ser justificada pela integração do gene no genoma da levedura.

Se assumirmos que as modificações observadas nas linhagens condicionadas (quando comparadas com as originais) serão conservadas nas linhagens curadas correspondentes, temos então possíveis novas linhagens de seleção . 


\subsection{Retransformação da linhagem LC7}

Mesmo sabendo que a LC7 ainda mantêm XIPiro, mas aparentemente perdeu o plasmídeo uma vez que perdeu a capacidade de crescer em meio mínimo, para testar a possível conservação das características observadas na linhagem condicionada L7XIXK, a LC7 foi transformada novamente com os mesmos plasmídeos originalmente inseridos (p424XI e P426XK que não passaram por processo de condicionamento), gerando a linhagem curada e retransformada LC-RT7.

Após a nova transformação da linhagem LC7 curada, foram escolhidas cinco colônias isoladas (A-E) da placa resultante da transformação. Estas foram inoculadas em $5 \mathrm{~mL}$ YX40, para testar se iriam readquirir a capacidade de crescer em xilose. Após 144 horas foi constatado que as cinco colônias para LC-RT7 readquiriram a capacidade de crescer em xilose. Foi escolhida aleatoriamente uma colônia (colônia B) como isolado representativo da população LC-RT7.

O padrão de crescimento da LC-RT7 foi testado por curva de crescimento (Figura 20), uma vez que era preciso analisar se as características diferenciadas da linhagem condicionada, eram conservadas mesmo após o processo de cura e nova transformação.

Pode ser observado que o perfil da levedura transformada, tanto em crescimento, quanto em formação de metabólitos, foi mantido quando comparado com a linhagem condicionada da qual derivou. 

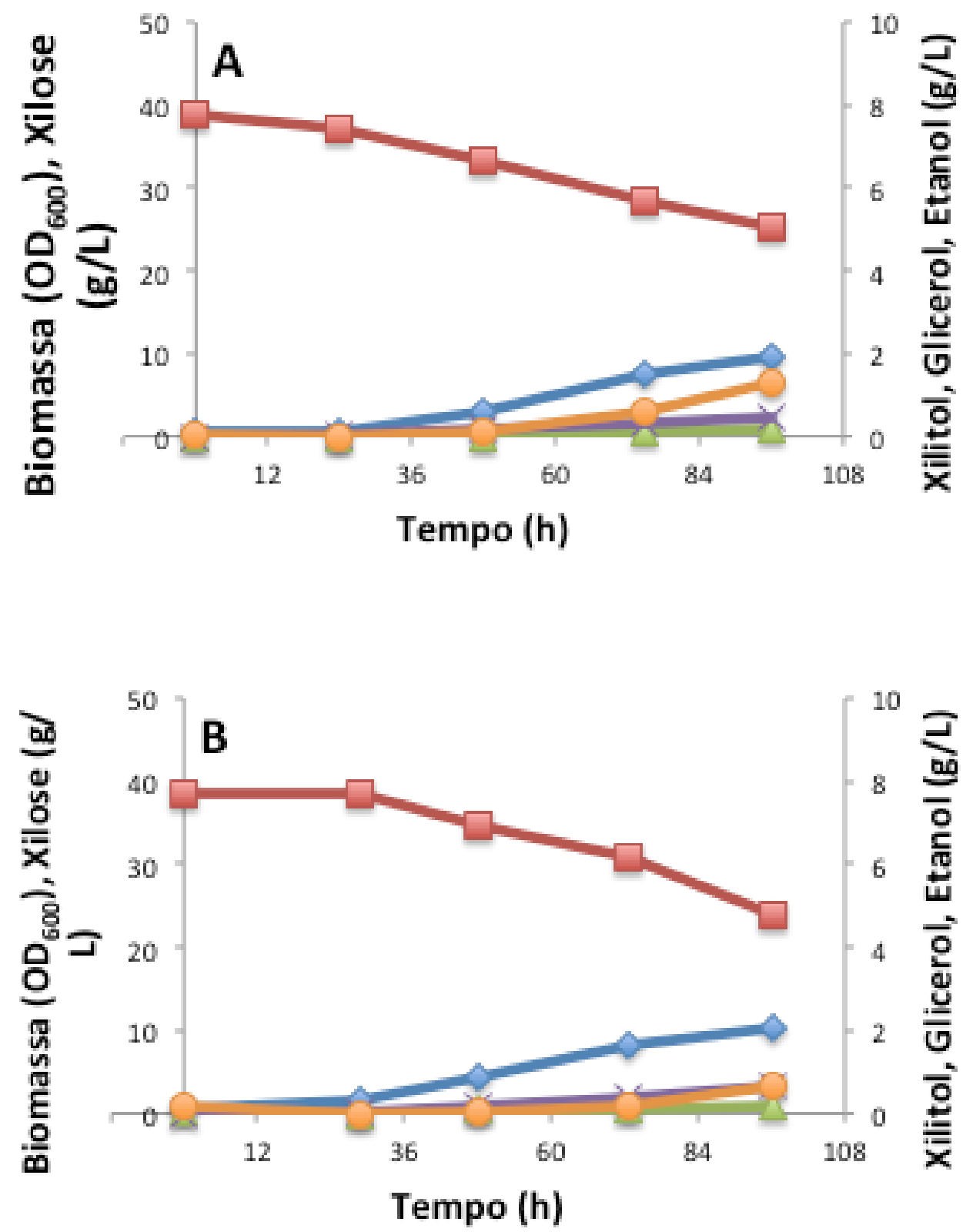

Figura 20: Comparação entre teste de crescimento da linhagem retransformada LCRT7 (A) e a condicionada L7XIXK (B). Consumo de xilose (vermelho), formação de biomassa (azul), glicerol (roxo), xilitol (verde) e etanol (laranja). Não houve produção de ácido acético em nenhuma das linhagens. Cada gráfico é um exemplo representativo de fermentação aeróbica, 96 horas, com $\mathrm{OD}_{600}$ inicial igual a 0,5 , feito em duplicata. 


\section{DISCUSSÃO}

A conversão eficiente de xilose à etanol é essencial para o aumento da produção de etanol de segunda geração (STAMBUK et al., 2008), uma vez que é o segundo açúcar mais abundante em biomassas lignocelulósicas (HAHN-HÄGERDAL et al., 2006). Para isso, estratégias de melhoramento genético de microrganismos para fermentação eficiente de xilose tem sido amplamente exploradas.

Duas principais vias têm sido utilizadas para construir linhagens recombinantes de S. cerevisiae capazes de utilizar xilose: a via da isomerização e da oxirredução (CAI; ZHANG; LI, 2012). Ao comparar a expressão das duas vias em linhagens isogênicas de S. cerevisiae, Karhumaa e colaboradores demonstraram diferenças importantes. Enquanto a linhagem expressando XI produz etanol com rendimento de $0,43 \mathrm{~g} \mathrm{~g}^{-1}$ próximo ao máximo teórico $(0,51 \mathrm{~g} / \mathrm{g})$, a linhagem expressando a via de oxirredução apresentou produtividade duas vezes maior (KARHUMAA et al., 2007). Neste trabalho, a via da isomerização da xilose foi escolhida como alternativa à via de oxirredução da xilose para construção de linhagens recombinantes, a fim de evitar os problemas envolvendo o desbalanço dos cofatores NADPH e NAD ${ }^{+}$, os quais são usados preferencialmente pelas enzimas XR e XDH, respectivamente (BRUINENBERG et al., 1983).

Linhagens recombinantes de $S$. cerevisiae foram construídas pela expressão da via de XI de Piromyces sp. Além disso, o efeito da superexpressão da xiluloquinase (XKSI) endógena de S. cerevisiae foi avaliado. As três linhagens obtidas foram: L2XI (expressa XI), L7XIФ (expressa XI e contém plasmídeo vazio) e L7XIXK (expressa XI e XK). Apesar de L2 e L7Ф expressarem somente XI, a primeira linhagem demonstrou maior taxa de crescimento em xilose. Isso pode ser explicado porque L2XI é regulado por uma marca de seleção, enquanto a levedura L7XIФ é regulada por duas, o que pode influenciar o padrão metabólico da levedura (PRONK, 2002). Desta forma, a dependência de dois plasmídeos, ao invés de um claramente influencia negativamente a levedura (KARIM; CURRAN; ALPER, 2013).

As linhagens L2XI e L7XIXIXK originais contendo apenas o gene de XIPiro apresentaram baixas taxas de crescimento aeróbico $\left(0,023 \mathrm{~h}^{-1} \pm 0,004\right.$ e $0,012 \mathrm{~h}^{-1} \pm 0,003$ respectivamente), porém ainda maiores que em KUYPER et al., 2003 (Tabela 14). Como 
as leveduras apresentam o mesmo background (ENTIAN; KOTTER, 2007), o melhor desempenho das linhagens deste estudo possivelmente deve-se ao promotor utilizado para expressão de XI (FLAGFELDT et al., 2009). Enquanto Kuyper e colaboradores utilizaram o promotor TPI1 (triosefosfato isomerase) para expressão da isomerase, neste trabalho foi utilizado o promotor GPD (gliceraldeído-3-fosfato dehidrogenase) (BITTER; EGAN, 1984). Em glicose, GPD tem maior atividade que TPI1, e o contrário ocorre quando o etanol é utilizado como fonte de carbono (FLAGFELDT et al., 2009).

A linhagem original L7XIФ não teve sua taxa de crescimento calculada, uma vez que o início da fase exponencial de crescimento não foi atingido no tempo de monitoramento da fermentação.

A linhagem L7XIXK original apresentou metade da taxa de crescimento de L2XI original, entretanto, suas taxas de produção de etanol e $\mathrm{OD}_{600}$ final foram muito superiores. Isto ocorreu devido ao início antecipado da fase exponencial de crescimento, em aproximadamente 72 horas, enquanto a L2XI só iniciou crescimento após 120 horas. Como demonstrado anteriormente, a superexpressão de XKS1 favorece o crescimento em xilose e produção de etanol (JOHANSSON et al., 2001; RICHARD; TOIVARI; PENTTILÄ, 2000).

Linhagens melhoradas de L2XI, L7XIФ e L7XIXK foram obtidas por condicionamento em xilose. Uma das vantagens de utilizar esta estratégia de melhoramento genético, é a regulação da expressão gênica a níveis ótimos feito pela própria levedura, evitando os efeitos não esperados da intervenção por engenharia genética (RODRIGUEZ-PEÑA et al., 1998; SAUER, 2001).

A taxa de crescimento da linhagem L2XI permaneceu praticamente a mesma, enquanto a de L7XIXK duplicou para $0,027 \mathrm{~h}^{-1} \pm 0,002$. A linhagem L7XIФ apresentou taxa de crescimento de $0,012 \mathrm{~h}^{-1} \pm 0,001$.

Em contrapartida, em condição aeróbica todas as linhagens condicionada apresentaram maior produção de etanol e consumo de xilose, além da redução da produção de xilitol. Isto pode ser reflexo de uma mudança metabólica, em que menos energia é investida no crescimento da levedura, e mais, na formação dos coprodutos (CORNISHBOWDEN; HOFMEYR; CARDENAS, 1995). 
O consumo de xilose nas linhagens condicionadas aumentou 1,8 8,2, 18,7 vezes para L7XIXK, L7XIФ e L2XI, respectivamente. A xilose consumida refletiu em uma maior quantidade de formação de coprodutos, especialmente etanol para as linhagens L2XI e L7XIXK. A linhagem L7XIФ produziu grandes quantidades de xilitol, indicando que talvez, os genes endógenos envolvidos no catabolismo da xilose estejam sendo expressos, como o GRE3, uma aldose-redutase endógena, envolvida na formação de xilitol (TRÄFF- BJERRE; JEPPSSON, 2004).

O condicionamento de linhagens utilizando bateladas repetitivas já demonstrou resultados semelhantes de aumento de produção de etanol e redução de xilitol, para linhagens capazes de fermentar pentoses (KUYPER et al., 2004, 2005; PARREIRAS et al., 2014).

Além das diferenças nas taxas de crescimento (Tabela 14), as linhagens melhoradas demonstraram uma forte redução na fase lag de crescimento, isto pode estar relacionado ao aumento da atividade de conversão de xilose a xilulose e mudanças no fluxo de carbono (HECTOR et al., 2011a).

Utilizando estratégia de condicionamento semelhante a aplicada neste estudo, Kuyper e colaboradores obtiveram a linhagem RWB 202-AFX, a qual apresentou crescimento 0,18 Tabela $^{-1}$ (Tabela 14)(KUYPER et al., 2004). As três linhagens condicionadas geradas neste trabalho apresentaram taxa de crescimento entre 5 e 15 menor que RWB 202-AFX. Esta diferença é possivelmente devido às diferentes pressões seletivas à que as linhagens foram submetidas.

De forma geral, em condições anaeróbicas as taxas e produtividade de etanol aumentaram para todas as linhagens condicionadas, enquanto o xilitol sofreu a maior redução das mesmas. 
Tabela 14: Comparação entre taxas de crescimento de Saccharomyces cerevisiae (linhagens isogênicas de CEN.PK) expressando XI de Piromyces sp em fermentação aeróbica de xilose como fonte de carbono.

\begin{tabular}{|c|c|c|c|}
\hline Linhagem & $\begin{array}{c}\text { Taxa } \\
\text { crescimento } \\
\text { (aeróbio) }\end{array}$ & Modificações & Referência \\
\hline L2 XI Original & $\begin{array}{c}0,023 \mathrm{~h}^{-1} \pm \\
0,004\end{array}$ & $\begin{array}{l}\text { Expressão heteróloga } \mathrm{de} \\
\text { Piromyces sp. XI }\end{array}$ & Este trabalho \\
\hline $\begin{array}{l}\text { L7XIФ } \\
\text { Original }\end{array}$ & n.c. & $\begin{array}{l}\text { Expressão heteróloga de } \\
\text { Piromyces sp. XI }\end{array}$ & Este trabalho \\
\hline $\begin{array}{l}\text { L7XIXK } \\
\text { Original }\end{array}$ & $0,012 \mathrm{~h}^{-1} \pm 0,003$ & \begin{tabular}{llr} 
Expressão & \multicolumn{2}{c}{ heteróloga de } \\
Piromyces & XI, superexpressão \\
XKS1 & &
\end{tabular} & Este trabalho \\
\hline $\begin{array}{l}\text { L2 XI } \\
\text { Condicionada }\end{array}$ & $0,033 \mathrm{~h}^{-1} \pm 0,021$ & $\begin{array}{l}\text { Expressão heteróloga de } \\
\text { Piromyces } s p . \quad \text { XI } \mathrm{e} \\
\text { condicionamento em meio mínimo } \\
\text { com xilose. }\end{array}$ & Este trabalho \\
\hline $\begin{array}{l}\text { L7XIФ } \\
\text { Condicionada }\end{array}$ & $\begin{array}{c}0,012 \mathrm{~h}^{-1} \pm \\
0,001\end{array}$ & $\begin{array}{l}\text { Expressão heteróloga de } \\
\text { Piromyces } s p . \quad \text { XI } \mathrm{e} \\
\text { condicionamento em meio mínimo } \\
\text { com xilose. }\end{array}$ & Este trabalho \\
\hline $\begin{array}{l}\text { L7XIXK } \\
\text { Condicionada }\end{array}$ & $0,027 \mathrm{~h}^{-1} \pm 0,002$ & $\begin{array}{l}\text { Expressão heteróloga de } \\
\text { Piromyces } s p . \quad \text { XI } \mathrm{e} \\
\text { condicionamento em meio mínimo } \\
\text { com xilose. }\end{array}$ & Este trabalho \\
\hline RWB 202 & $0,005 \mathrm{~h}^{-1}$ & $\begin{array}{l}\text { Expressão heteróloga } \\
\text { Piromyces sp. XI }\end{array}$ & $\begin{array}{l}\text { (KUYPER et } \\
\text { al., 2003) }\end{array}$ \\
\hline RWB202-AFX & $0,18 \mathrm{~h}^{-1}$ & $\begin{array}{l}\text { Linhagem RWB-202 pós } \\
\text { condicionamento (158 dias/ } 50 \\
\text { ciclos em meio com xilose) }\end{array}$ & $\begin{array}{l}\text { (KUYPER et } \\
\text { al., 2004) }\end{array}$ \\
\hline TMB 3066 & $0,02 h^{-1}$ & $\begin{array}{lcc}\text { Expressão } & \text { heteróloga } & \text { de } \\
\text { Piromyces } & s p . & \text { XI, }\end{array}$ & $\begin{array}{l}\text { (KARHUMAA } \\
\text { et al., 2007) }\end{array}$ \\
\hline
\end{tabular}




\begin{tabular}{|c|c|c|c|}
\hline & & $\begin{array}{l}\text { superexpressando XKS1, } T K L 1, \\
R P E 1, R K I 1, H X T 7 \text { e deleção gre3 }\end{array}$ & \\
\hline RWB217 & $0,22 \mathrm{~h}^{-1} \pm 0,01$ & $\begin{array}{l}\text { Expressão } \text { heteróloga de } \\
\text { Piromyces sp. XI, superexpressão } \\
\text { XKS1, TKL1, RPE1, RKI1 e } \\
\text { deleção de gre3 }\end{array}$ & $\begin{array}{l}\text { (KUYPER, } \\
\text { MARKO et al., } \\
\text { 2005) }\end{array}$ \\
\hline
\end{tabular}

Anaerobicamente, as linhagens originais e condicionadas mantiveram taxa de crescimento parecidas tanto na fase de consumo da glicose quanto na fase de consumo de xilose (Tabela 12). As linhagens original e condicionada de L2XI no fermentador, tiveram taxas parecidas de produção de etanol, ácido acético e glicerol, entretanto, houve uma redução na quantidade de xilitol produzida de $72,4 \%$ e o aumento de $49,8 \%$ na taxa de consumo específico de xilose.

Lee e colaboradores mostraram que diversas mutações na XI resultam em um aumento de $71 \%$ na atividade da enzima, além de aumentar taxa de crescimento e consumo de xilose (LEE; JELLISON; ALPER, 2012). Também foi demonstrado que o aumento da atividade de XK resulta em menor produção de xilitol (JOHANSSON et al., 2001). Estas duas principais hipóteses foram testadas como possíveis justificativas as melhorias observadas nas leveduras condicionadas.

Inicialmente foi investigado se houve alteração nos níveis de atividade de XK. Os resultados do ensaio da atividade enzimática indicam que não houve diferença relevante nos níveis de expressão de XK para as linhagens condicionadas e originais, à exceção da linhagem L2XI original, que teve maior atividade que todas as outras. A baixa atividade de XK pode ser um gargalo para a utilização eficiente de xilose por linhagens expressando a via da isomerização ou da oxirredução (TOIVARI et al., 2001). Entretanto, uma vez que linhagens selvagens são capazes de fermentar D-xilulose, significaria que a XKS1 endógena de S. cerevisiae pode ter expressão suficiente para viabilizar o crescimento de linhagens sem superexpressão de XK nas condições avaliadas neste estudo (KUYPER et al., 2003). 
É sabido portanto, que a baixa atividade de XK é um fator limitante do metabolismo de xilulose em S. cerevisiae, e que a sua superexpressão pode aumentar a utilização de xilose (TOIVARI et al., 2001) e produção de etanol em fermentação anaeróbica (HO; CHEN; BRAINARD, 1998). Entretanto, a superexpressão da XK também pode resultar em níveis tóxicos de atividade da enzima que inibem o meta de produção de etanol (JIN; JEFFRIES, 2003). Por isso, é necessário compreender profundamente os efeitos das modificações genéticas pontuais nas vias metabólicas (JOHANSSON et al., 2001)

Outra hipótese investigada para explicar os melhoramentos observados, foi a de possíveis mutações terem ocorrido na sequência da XIPiro, as quais favoreceram o desempenho da levedura. Lee e colaboradores demonstraram que a mutações provocadas na sequência de XylA de Piromyces sp. podem levar ao aumento da atividade da enzima, crescimento, consumo de xilose e produção de etanol (LEE; JELLISON; ALPER, 2012).

Contudo, o resultado do sequenciamento neste estudo indicou que não ocorreram mutações nas sequências de XI contidas nas leveduras condicionadas. Porém, as extremidades das sequências do gene tiveram baixa cobertura e precisarão ser resequenciadas para reconfirmação deste resultado. Apesar dos níveis de atividade de XI não terem sido investigados sabe-se que esse tem grande impacto no desempenho de linhagens expressando tal enzima (LEE; JELLISON; ALPER, 2012).

Uma vez que não houve mutações no gene de XI das linhagens condicionadas, o melhor desempenho pode ter ocorrido por modificações fora do plasmídeo. Afim de investigar essa possibilidade, foram feitos experimentos para cura das leveduras. Se de fato, as modificações ocorreram fora do plasmídeo (como por exemplo, a nível genômico), a levedura curada perderia a capacidade de crescer em xilose pela ausência dos plasmídeos, mas quando retransformada com estes, readquiriria esta capacidade, mantendo as características da linhagem condicionada.

Os resultados da cura não foram conclusivos. Haja vista, o fato que as leveduras LC2 e LC $\Phi$ perderam a capacidade de crescer em meio mínimo quer em presença de glicose como de xilose como única fonte de carbono (Figura 18). Entretanto, foram capazes de demonstrar crescimento em meios YPX e YG20 ainda que o crescimento de 
LC $\Phi$ tenha sido muito lento (Figura 18) indicando que as leveduras ainda possuem a capacidade de crescer em xilose. Podemos assumir que os plasmídeos não foram completamente removidos da levedura, mas o número de cópias foi reduzido, interferindo na capacidade de crescimento destes em meio seletivo. Esta hipótese é reforçada pela presença do gene XylA nas três linhagens resultantes da cura.

No caso de LC7 (Figura 18), a ausência de crescimento em meio mínimo quer suplementado com glicose ou com xilose, sugere que a levedura perdeu a marca de seleção. Porém, o crescimento observado em meio YPX, e a presença do gene identificada pela PCR, indicam que o gene continua sendo expresso. É preciso investigar a possibilidade do gene de XIPiro ter sido integrado no genoma das leveduras.

Com a eventual obtenção de uma linhagem curada e condicionada ao crescimento em xilose, podemos utilizar esta linhagem como modelo para caracterização de novas enzimas da via catabólica da xilose, como por exemplo, na investigação de potenciais novas xiloses isomerases. Com a linhagem condicionada e bem descrita, podemos transformá-las com os novos genes, e obter resultados mais rapidamente que as linhagens originalmente utilizadas, CEN.PK 113.C ou CEN.PK 14.A.

Mesmo com o gene de XIPiro presente na linhagem LC7, após a retransformação desta com os plasmídeos p424-XI e p426-XK, foi observado perfil de crescimento e produção de metabólitos se manteve muito próximo da levedura condicionada. Isto pode indicar que as diferenças encontradas na levedura podem ter ocorrido a nível genômico, e foram conservadas através da cura.

Sabe-se que a superexpressão de genes da via não oxidativa das pentoses fosfato, favorece o metabolismo de xilose. De fato, isto pode explicar o melhor desempenho da linhagem retransformada e das obtidas por condicionamento (KARHUMAA et al., 2007). Adicionalmente, outros fatores que limitam o metabolismo de xilose devem ser avaliados para compreensão dos fatores que influenciam as melhorias observadas neste trabalho, tais como transportadores de açúcares.

As principais hipóteses de que diferenças observadas nas linhagens condicionadas tenham ocorrido por: mutações na XI, ou mudanças nos níveis de atividade de XK foram eliminadas. Sendo assim, os principais alvos para futuras investigações se tornam eventos anteriores ou posteriores a XI. Anteriormente à isomerase na via de catabolismo da 
xilose, pode-se investigar a afinidade dos transportadores de açúcares, uma vez que a xilose utiliza transportadores de glicose para ser internalizada (KOTTER; CIRIACY, 1993; SEDLAK; HO, 2004). Posteriormente à XK na vida de catabolismo de xilose, temos a via da pentose fosfato. Os efeitos das modificações nas enzimas da via da pentose fosfato já foram amplamente investigados com efeitos positivos na fermentação de xilose (DIAO et al., 2013; KARHUMAA et al., 2007; KUYPER et al., 2005; SHEN et al., 2012). 


\section{CONCLUSÕES}

Neste trabalho, foram construídas três linhagens de $S$. cerevisiae expressando somente XI (L2XI), a combinação de XI com XK (L7XIXK) e XI com plasmídeo vazio (L7XIФ). Diante dos resultados apresentados, fica claro que a expressão de XK resultou em linhagem com melhor capacidade de fermentar xilose, tendo em vista que houve maior o consumo do açúcar e formação de etanol.

As três linhagens L2XI, L7XIФ, L7XIXK foram submetidas a processo de condicionamento em xilose e três linhagens melhoradas geneticamente de cada subpopulação foram obtidas. As linhagens condicionadas tiveram melhor desempenho na conversão de xilose a etanol, tanto aerobicamente quanto anaerobicamente. Quando comparadas com as linhagens originais, as linhagens L2XI, L7XIФ, L7XIXK condicionadas demonstraram taxas mais altas de consumo de xilose e de produção de etanol, enquanto a produção de xilitol foi reduzida. Além disso, observou-se redução na fase lag de crescimento e aumento nas taxas de crescimento aeróbico para as três linhagens condicionadas. Dentre as três linhagens condicionadas, a linhagem expressando $X y l A$ e superexpressando $X K S I$ demonstrou maior taxa de consumo específico de xilose e produção de etanol.

As melhorias observadas nas linhagens condicionadas não estão relacionadas a mudanças nos níveis de atividade de xiluloquinase e nem a mutações na sequência gênica da xilose isomerase. Possíveis mudanças a nível de transporte de xilose, e níveis de atividade de xilose isomerase não foram investigados nesse estudo.

Após processo de cura concluiu-se que as mutações resultantes na melhoria da linhagem curada 7, derivada (L7XIXK) provavelmente não ocorreram nível plasmidial. A retransformação desta levedura com os plasmídeos expressando XylA e XKS1 permitiu que a levedura apresentasse padrão similar a condicionada. Portanto, a linhagem obtida demonstra-se como uma excelente ferramenta para a avaliação de novas enzimas relacionadas ao metabolismo de xilose. 


\section{PERSPECTIVAS}

Para as próximas etapas do trabalho, o primeiro ponto a ser investigado são os alvos das possíveis modificações que ocorreram nas linhagens condicionadas. O sequenciamento total das linhagens condicionadas pode ser feito para avaliar se houve alguma modificação na sequencia genômica que explique estas diferenças. Além disso, os principais alvos de futuras investigações são modificações nos transportadores de açúcares, e nas enzimas da via da pentose fosfato. Além disso, as replicatas biológicas da atividade enzimática devem ser feitas para confirmar os dados obtidos.

É necessário repetir o sequenciamento das XI dos plasmídeos das leveduras condicionadas para confirmar que não houve mutações nas regiões de baixa qualidade.

Nas linhagens condicionadas, um novo processo de condicionamento pode ser feito sob diferentes condições, incluindo seleção anaeróbia.

O próximo desafio é transportar os genes e avaliar seu efeito em linhagens industriais. Vetores integrativos de XIPiro e XK já foram construídos.

O processo de cura para as linhagens L2XI, L7XIФ será continuado, enquanto novas colônias de L7XIXK serão avaliadas para a perda dos plasmídeos. Caso seja encontrada uma linhagem curada, esta seria idealmente uma linhagem de seleção para possíveis novas xiloses isomerases. Sequências codificadoras de possíveis novas XI já foram identificadas, sintetizadas e transformadas em CEN.PK 113.14A. Serão feitas avaliações comparando a atividade destes novos genes à linhagem original, e à condicionada de L2XI.

A linhagem LC7 será investigada quanto a nossa suspeita de integração de XIPiro e perda do plasmídeo. Também seria interessante investigar a atividade enzimática da XI inserida na linhagem LC7, e compará-la com as linhagens L7XIXK original e condicionada, para avaliar os níveis da enzima. 


\section{REFERÊNCIAS BIBLIOGRÁFICAS}

ALMEIDA, J. R. et al. Increased tolerance and conversion of inhibitors in lignocellulosic hydrolysates bySaccharomyces cerevisiae. Journal of Chemical Technology \& Biotechnology, v. 82, n. 4, p. 340-349, abr. 2007.

ALMEIDA, J. R. M. et al. Stress-related challenges in pentose fermentation to ethanol by the yeast Saccharomyces cerevisiae. Biotechnology journal, v. 6, n. 3, p. 286-99, mar. 2011.

ANP - Agência Nacional de Petróleo. Boletim anual de preços 2014 .Disponível em:

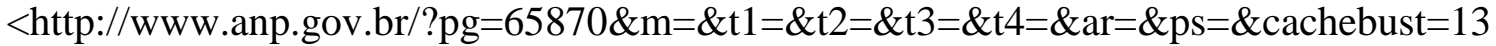
68609471895>.

BATT, C. A et al. Direct evidence for a xylose metabolic pathway in Saccharomyces cerevisiae. Biotechnology and bioengineering, v. 28, p. 549-553, 1986.

BHOSALE, S. H.; RAO, M. B.; DESHPANDE, V. V. Molecular and industrial aspects of glucose isomerase. Microbiological reviews, v. 60, n. 2, p. 280-300, 1996.

BITTER, G. A; EGAN, K. M. Expression of heterologous genes in Saccharomyces cerevisiae from vectors utilizing the glyceraldehyde-3-phosphate dehydrogenase gene promoter. Gene, v. 32, p. 263-274, 1984.

BRUINENBERG, P. M. et al. The role of redox balances in the anaerobic fermentation of xylose by yeasts. European Journal of Applied Microbiology and Biotechnology, v. 18, p. 287-292, 1983.

CAI, Z.; ZHANG, B.; LI, Y. Engineering Saccharomyces cerevisiae for efficient anaerobic xylose fermentation: reflections and perspectives. Biotechnology journal, v. 7, n. 1, p. 34-46, jan. 2012.

CARRASCO, C. et al. SO2-catalyzed steam pretreatment and fermentation of enzymatically hydrolyzed sugarcane bagasse. Enzyme and Microbial Technology, v. 46, p. 64-73, 2010.

CHERUBINI, F. The biorefinery concept: Using biomass instead of oil for producing energy and chemicals. Energy Conversion and Management, v. 51, n. 7, p. 1412-1421, 2010.

CLARK, J. H.; LUQUE, R.; MATHARU, A. S. Green chemistry, biofuels, and biorefinery. Annual review of chemical and biomolecular engineering, v. 3, p. 183207, jan. 2012. 
CORNISHBOWDEN, A.; HOFMEYR, J. H. S.; CARDENAS, M. L. Strategies for Manipulating Metabolic Fluxes in Biotechnology. Bioorganic Chemistry, v. 23, p. 439449, 1995.

COTTRELLE, P. et al. Cloning, nucleotide sequence, and expression of one of two genes coding for yeast elongation factor la. Journal of biological chemistry, v. 260, n. 84, p. 3090-3096, 1985.

DELLA-BIANCA, B. E.; GOMBERT, A. K. Stress tolerance and growth physiology of yeast strains from the Brazilian fuel ethanol industry. Antonie van Leeuwenhoek, International Journal of General and Molecular Microbiology, v. 104, p. 1083-1095, 2013.

DEMIRBAS, A. Biofuels sources, biofuel policy, biofuel economy and global biofuel projections. Energy Conversion and Management, v. 49, p. 2106-2116, 2008.

DEMIRBAS, A. Political, economic and environmental impacts of biofuels: A review. Applied Energy, v. 86, p. S108-S117, 2009.

DIAO, L. et al. Construction of fast xylose-fermenting yeast based on industrial ethanolproducing diploid Saccharomyces cerevisiae by rational design and adaptive evolution. BMC biotechnology, v. 13, p. 110, 2013.

DING, M. et al. Identification, expression, and characterization of the highly conserved D -xylose isomerase in animals. Acta Biochimica et Biophysica Hungarica, v. 41, n. 2, p. 116-122, 2009.

EIA - U.S. Enegy Information Administration. International Energy Statistics - U.S. Energy Information Administration. Disponível em: $<$ http://www.eia.gov/cfapps/ipdbproject/IEDIndex3.cfm?tid=5\&pid=53\&aid=1>. Acesso em: 20 mar. 2015a.

EIA - U.S. Enegy Information Administration. Brazil Analysis. Disponível em: <http://www.eia.gov/countries/cab.cfm?fips=BR>. Acesso em: 20 mar. 2015 b.

ENTIAN, K.; KOTTER, P. Yeast Gene Analysis - Second Edition. In: Methods in Microbiology. Methods in Microbiology. [s.1.] Elsevier, 2007. v. 36p. 629-666.

FAB - Força Aérea Brasileira. Brasil lança com sucesso primeiro foguete nacional com combustível líquido. Disponível em: <http://www.fab.mil.br/noticias/mostra/19799/ESPA\%C3\%87O---Brasil-lan\%C3\%A7acom-sucesso-primeiro-foguete-nacional-com-combust\%C3\%ADvel-1\%C3\%ADquido>. Acesso em: 13 mar. 2015. 
FERREIRA-LEITÃO, V. et al. An approach to the utilisation of $\mathrm{CO} 2$ as impregnating agent in steam pretreatment of sugar cane bagasse and leaves for ethanol production. Biotechnology for biofuels, v. 3, n. 1, p. 7, jan. 2010.

FLAGFELDT, D. B. et al. Characterization of chromosomal integration sites for heterologous gene expression in Saccharomyces cerevisiae. Yeast (Chichester, England), v. 26, n. July, p. 545-551, 2009.

GÁRDONYI, M.; HAHN-HÄGERDAL, B. The Streptomyces rubiginosus xylose isomerase is misfolded when expressed in Saccharomyces cerevisiae. Enzyme and Microbial Technology, v. 32, p. 252-259, 2003.

Geneious. Disponível em: <http://www.geneious.com/>. Acesso em: 17 mar. 2015.

GIETZ, R. D.; SCHIESTL, R. H. Large-scale high-efficiency yeast transformation using the LiAc/SS carrier DNA/PEG method. Nature Protocols, v. 2, n. 1, p. 38-41, jan. 2007.

GOFFEAU, A. et al. Life with 6000 Genes. Science, v. 274, n. 5287, p. 546-567, 25 out. 1996.

GONG, C. S. et al. Conversion of pentoses by yeasts. Biotechnology and bioengineering, v. 25, p. 85-102, 1983.

GORDINHO, M. C. Do álcool ao etanol: trajetória única. [s.l: s.n.]. Disponível em: $<$ http://sugarcane.org/resource-library/books/>.

HAHN-HÄGERDAL, B. et al. Bio-ethanol - the fuel of tomorrow from the residues of today. Trends in Biotechnology, v. 24, n. 12, p. 549-556, 2006.

HAHN-HÄGERDAL, B. et al. Metabolic engineering for pentose utilization in Saccharomyces cerevisiae. Advances in biochemical engineering/biotechnology, v. 108, n. May, p. 147-77, jan. 2007.

HAMACHER, T. et al. Characterization of the xylose-transporting properties of yeast hexose transporters and their influence on xylose utilization. Microbiology, v. 148, p. 2783-2788, 2002.

HE, Y.; WANG, S.; LAI, K. K. Global economic activity and crude oil prices: A cointegration analysis. Energy Economics, v. 32, n. 4, p. 868-876, 2010.

HECTOR, R. E. et al. Saccharomyces cerevisiae engineered for xylose metabolism requires gluconeogenesis and the oxidative branch of the pentose phosphate pathway for aerobic xylose assimilation. Yeast, v. 28, n. August, p. 645-660, 2011a. 
HECTOR, R. E. et al. Engineering industrial Saccharomyces cerevisiae strains for xylose fermentation and comparison for switchgrass conversion. Journal of industrial microbiology \& biotechnology, v. 38, n. 9, p. 1193-202, set. 2011 b.

HO, N. W. Y.; CHEN, Z.; BRAINARD, A. P. Genetically engineered Saccharomyces yeast capable of effective cofermentation of glucose and xylose. Applied and Environmental Microbiology, v. 64, n. 5, p. 1852-1859, 1998.

HÖÖK, M.; TANG, X. Depletion of fossil fuels and anthropogenic climate change-A review. Energy Policy, v. 52, p. 797-809, 2013.

HSU, T.-C. et al. Effect of dilute acid pretreatment of rice straw on structural properties and enzymatic hydrolysis. Bioresource technology, v. 101, n. 13, p. 4907-4913, 2010.

HUNTER, S. et al. InterPro in 2011: New developments in the family and domain prediction database. Nucleic Acids Research, v. 40, n. November 2011, p. 306-312, 2012.

IEA - International Energy Agency. World Energy Outlook. Executive Summary. Disponível em: 〈http://www.iea.org/Textbase/npsum/WEO2013SUM.pdf>. Acesso em: 6 mar. 2015.

IEA - International Energy Agency. IEA Bioenergy Task 39 - Commercializing Liquid Biofuels. Disponível em: <http://task39.org/about/definitions/>. Acesso em: 6 mar. 2015.

INTERPRO - Protein sequence analysis and classification. Species: Xylose isomerase (IPR001998) < InterPro < EMBL-EBI. Disponível em: <http://www.ebi.ac.uk/interpro/entry/IPR001998/taxonomy>. Acesso em: 26 mar. 2015.

JANK, M. S. Opinião - Palavra da Presidência - Unica. Disponível em: <http://www.unica.com.br/palavra-do-presidente/4303397592039673243/etanolbeneficios-por-cento2C-riscos-e-desafios/>. Acesso em: 22 mar. 2015.

JIN, Y.-S.; JEFFRIES, T. W. Changing flux of xylose metabolites by altering expression of xylose reductase and xylitol dehydrogenase in recombinant Saccharomyces cerevisiae. Applied biochemistry and biotechnology, v. 105 -108, p. 277-286, 2003.

JOHANSSON, B. et al. Xylulokinase Overexpression in Two Strains of Saccharomyces cerevisiae Also Expressing Xylose Reductase and Xylitol Dehydrogenase and Its Effect on Fermentation of Xylose and Lignocellulosic Hydrolysate. Applied and Environmental Microbiology, v. 67, n. 9, p. 4249-4255, 2001.

JOHNSEN, U. et al. D-xylose degradation pathway in the halophilic archaeon Haloferax volcanii. Journal of Biological Chemistry, v. 284, n. 40, p. 27290-27303, 2009. 
JOHNSEN, U.; SCHÖNHEIT, P. Novel xylose dehydrogenase in the halophilic archaeon Haloarcula marismortui. Journal of Bacteriology, v. 186, n. 18, p. 6198-6207, 2004.

KAMP, A. F.; LARIVIERE, J. W. M.; VERHOEVEN, W. (EDS.). Albert Jan Kluyver, his life and work. [s.1.] Amsterdam, North-Holland Pub. Co.; New York, Interscience Publishers, 1959. p. 604

KARHUMAA, K. et al. Comparison of the xylose reductase-xylitol dehydrogenase and the xylose isomerase pathways for xylose fermentation by recombinant Saccharomyces cerevisiae. Microbial cell factories, v. 6, p. 5, jan. 2007.

KARIM, A. S.; CURRAN, K. A.; ALPER, H. S. Characterization of plasmid burden and copy number in Saccharomyces cerevisiae for optimization of metabolic engineering applications. FEMS Yeast Research, v. 13, p. 107-116, 2013.

KEARSE, M. et al. Geneious Basic: An integrated and extendable desktop software platform for the organization and analysis of sequence data. Bioinformatics, v. 28, n. 12, p. 1647-1649, 2012.

KIM, S. R. et al. Simultaneous co-fermentation of mixed sugars: a promising strategy for producing cellulosic ethanol. Trends in biotechnology, v. 30, n. 5, p. 274-82, maio 2012.

KOTTER, P.; CIRIACY, M. Xylose fermentation by Saccharomyces cerevisiae. Applied Microbiology and Biotechnology, v. 38, p. 776-783, 1993.

KUYPER, M. et al. High-level functional expression of a fungal xylose isomerase: the key to e/cient ethanolic fermentation of xylose by Saccharomyces cerevisiae? FEMS Yeast Research, v. 4, n. 1, p. 69-78, out. 2003.

KUYPER, M. et al. Minimal metabolic engineering of Saccharomyces cerevisiae for efficient anaerobic xylose fermentation: A proof of principle. FEMS Yeast Research, v. 4, p. 655-664, 2004.

KUYPER, M. et al. Metabolic engineering of a xylose-isomerase-expressing Saccharomyces cerevisiae strain for rapid anaerobic xylose fermentation. FEMS yeast research, v. 5, n. 4-5, p. 399-409, fev. 2005.

LEE, S. M.; JELLISON, T.; ALPER, H. S. Directed evolution of xylose isomerase for improved xylose catabolism and fermentation in the yeast Saccharomyces cerevisiae. Applied and Environmental Microbiology, v. 78, n. June, p. 5708-5716, 2012.

LENNARTSSON, P. R.; ERLANDSSON, P.; TAHERZADEH, M. J. Integration of the first and second generation bioethanol processes and the importance of by-products. Bioresource Technology, v. 165, p. 3-8, 2014. 
LINDE, M.; GALBE, M.; ZACCHI, G. Simultaneous saccharification and fermentation of steam-pretreated barley straw at low enzyme loadings and low yeast concentration. Enzyme and Microbial Technology, v. 40, p. 1100-1107, 2007.

LUCCIO, E. D. I. et al. STRUCTURAL AND KINETIC STUDIES OF INDUCED FIT IN XYLULOSE KINASE FROM E. COLI. J Mol Biol., v. 365, n. 3, p. 783-798, 2007.

MACHADO, C. M. M. Microrganismos na Produção de Biocombustíveis Líquidos. 1a edição ed. Brasília: EMBRAPA, 2013. p. 319

MATSUSHIKA, A. et al. Ethanol production from xylose in engineered Saccharomyces cerevisiae strains: Current state and perspectives. Applied Microbiology and Biotechnology, v. 84, p. 37-53, 2009.

MENON, V.; RAO, M. Trends in bioconversion of lignocellulose: Biofuels, platform chemicals \& biorefinery concept. Progress in Energy and Combustion Science, v. 38, n. 4, p. 522-550, ago. 2012.

MicroPulser ${ }^{\mathrm{TM}}$ Electroporation Apparatus Operating Instructions and Applications Guide , 2000. Disponível em: <papers://89d36d58-78ed-4e44-9192-508166ce5564/Paper/p184>

MOES, C.; PRETORIUS, I.; ZYL, W. Cloning and expression of the Clostridium thermosulfurogenes D-xylose isomerase gene (xyLA) in Saccharomyces cerevisiae. Biotechnology Letters, v. 18, n. 3, p. 269-274, 1996.

MOREIRA, J. R.; GOLDEMBERG, J. The alcohol program. Energy Policy, v. 27, p. 229-245, 1999.

MUMBERG, D.; MULIER, R.; FUNK, M. Regulatable promoters of Saccharomyces cerevisiae: comparison of transcriptional activity and their use for heterologous expression. Nucleic Acids Research, v. 22, n. 25, p. 5767-5768, 1994.

NEVOIGT, E. Progress in metabolic engineering of Saccharomyces cerevisiae. Microbiology and molecular biology reviews : MMBR, v. 72, n. 3, p. 379-412, 2008.

NIELSEN, J. et al. Metabolic engineering of yeast for production of fuels and chemicals. Current opinion in biotechnology, v. 24, n. 3, p. 398-404, jun. 2013.

NIGAM, P. S.; SINGH, A. Production of liquid biofuels from renewable resources. Progress in Energy and Combustion Science, v. 37, p. 52-68, 2011.

NYLUND, N.-O.; AAKKO-SAKSA, P.; SIPILÄ, K. Status and outlook for biofuels, other alternative fuels and new vehicles, 2008. Disponível em: $<$ http://www.ieabioenergy.com/wp-content/uploads/2013/10/Status-and-outlook-forbiofuels-other-alternative-fuels-and-new-vehicles.pdf $>$. Acesso em: 6 mar. 2015. 
ÖHGREN, K. et al. Effect of hemicellulose and lignin removal on enzymatic hydrolysis of steam pretreated corn stover. Bioresource Technology, v. 98, p. 2503-2510, 2007.

OLSSON, L.; HAHN-HÄGERDAL, B. Fermentative performance of bacteria and yeasts in lignocellulose hydrolysates. Process Biochemistry, v. 28, p. 249-257, 1993.

PAES, B. G.; ALMEIDA, J. R. M. Genetic improvement of microorganisms for applications in biorefineries. n. Figure 1, p. 1-10, 2014.

PARACHIN, N. S.; ALMEIDA, J. R. M. MICRORGANISMOS PARA A PRODUÇÃO DE ETANOL: FERMENTAÇÃO DE PENTOSES E HEXOSES. In: Microrganismos na Produção de Bicombustíveis Líquidos. Brasília: EMBRAPA, 2013. p. 189- 204.

PARREIRAS, L. S. et al. Engineering and Two-Stage Evolution of a Lignocellulosic Hydrolysate-Tolerant Saccharomyces cerevisiae Strain for Anaerobic Fermentation of Xylose from AFEX Pretreated Corn Stover. PLoS One. v. 9, n. 9, 2014.

PETERSON, T. C.; CONNOLLEY, W. M.; FLECK, J. The myth of the 1970s global cooling scientific consensus. Bulletin of the American Meteorological Society, v. 89, n. February, p. 1325-1337, 2008.

PRONK, J. T. Auxotrophic Yeast Strains in Fundamental and Applied Research. Applied and environmental microbiology, v. 68, n. 5, p. 2095-2100, 2002.

PUPPÁN, D. Environmental evaluation of biofuels. Periodica Polytechnica, Social and Management Sciences, v. 10, n. 1, p. 95-116, 2002.

RÉMOND, C. et al. Combination of ammonia and xylanase pretreatments: Impact on enzymatic xylan and cellulose recovery from wheat straw. Bioresource Technology, v. 101, n. 17, p. 6712-6717, 2010.

RICHARD, P.; TOIVARI, M. H.; PENTTILÄ, M. The role of xylulokinase in Saccharomyces cerevisiae xylulose catabolism. FEMS Microbiology Letters, v. 190, p. $39-43,2000$.

ROBZYK, K.; KASSIR, Y. A simple and highly efficient procedure for rescuing autonomous plasmids from yeast. Nucleic acids research, v. 20, n. 14, p. 3790, 1992.

RODRIGUEZ-PEÑA, J. M. et al. The YGR194c (XKS1) gene encodes the xylulokinase from the budding yeast Saccharomyces cerevisiae. FEMS Microbiology Letters, v. 162, p. $155-160,1998$.

ROTHEN, S. A. et al. Growth characteristics of Escherichia coli HB101[pGEc47] on defined medium. Biotechnology and bioengineering, v. 58, n. 1, p. 92-100, 5 abr. 1998. 
SAHA, B. C. Lignocellulose Biodegradation and Applications in Biotechnology Structure and Composition of Lignocellulosic Biomass. American Chemical Society, p. 2-33, 2004.

SAMBROOK, J.; RUSSEL, D. W. Molecular Cloning: A laboratory Manual. Third Edit ed. Cold Spring Harbor, NY: Cold Spring Harbor Laboratory Press, 2001.

SANGER, F.; COULSON, A R. A rapid method for determining sequences in DNA by primed synthesis with DNA polymerase. Journal of molecular biology, v. 94, p. 441$448,1975$.

SARTHIY, A. V et al. Expression of the Escherichia coli Xylose Isomerase Gene in Saccharomyces cerevisiae S1. Applied and Environmental Microbiology. v. 53, n. 9, p. 1996-2000, 1987.

SAUER, U. Evolutionary engineering of industrially important microbial phenotypes. Advances in biochemical engineering/biotechnology, v. 73, p. 129-169, 2001.

SEDLAK, M.; HO, N. W. Y. Characterization of the effectiveness of hexose transporters for transporting xylose during glucose and xylose co-fermentation by a recombinant Saccharomyces yeast. Yeast, v. 21, p. 671-684, 2004.

SHEN, Y. et al. An efficient xylose-fermenting recombinant Saccharomyces cerevisiae strain obtained through adaptive evolution and its global transcription profile. Applied Microbiology and Biotechnology, v. 96, p. 1079-1091, 2012.

SLUITER, J. B. et al. Compositional analysis of lignocellulosic feedstocks. 1. Review and description of methods. Journal of Agricultural and Food Chemistry, v. 58, p. 9043-9053, 2010.

STAMBUK, B. U. et al. Brazilian potential for biomass ethanol: Challenge of using hexose and pentose co- fermenting yeast strains. Journal of Scientific \& Industrial Research. v. 67, n. November, p. 918-926, 2008.

SUBTIL, T.; BOLES, E. Competition between pentoses and glucose during uptake and catabolism in recombinant Saccharomyces cerevisiae. Biotechnology for Biofuels, v. 5, n. 1, p. 14, 2012.

TAYLOR, G. Biofuels and the biorefinery concept. Energy Policy, v. 36, n. 12, p. 44064409, dez. 2008.

TOIVARI, M. H. et al. Conversion of xylose to ethanol by recombinant Saccharomyces cerevisiae: importance of xylulokinase (XKS1) and oxygen availability. Metabolic engineering, v. 3, p. 236-249, 2001. 
TOIVARI, M. H. et al. Endogenous Xylose Pathway in Saccharomyces cerevisiae. Applied And Environmental Microbiology, V. 70, N. 6, P. 3681-3686, 2004.

TRÄFF- BJERRE, K.; JEPPSSON, M. Endogenous NADPH- dependent aldose reductase activity influences product formation during xylose consumption in recombinant Saccharomyces. Yeast, p. 141-150, 2004.

UENG, P. P. et al. D-XYLULOSE FERMENTATION IN YEASTS. Biotechnology letters, v. 3, n. 6, p. 315-320, 1981.

UNICA - UNIÃO DA INDÚSTRIA DE CANA-DE-AÇÚCAR -. Disponível em: <http://www.unicadata.com.br/>. Acesso em: 7 maio. 2015.

UNICA - UNIÃO DA INDÚSTRIA DA CANA DE AÇÚCAR. Carro flex com etanol : uma atitude inteligente ., 2010. Disponível em: <http://www.unica.com.br/documentos/publicacoes/>

UNICA - UNIÃO DA INDÚSTRIA DA CANA DE AÇÚCAR. Cartilha Movimento Mais Etanol, 2011a. Disponível em: <http://www.unica.com.br/documentos/publicacoes/>

UNICA - UNIÃO DA INDÚSTRIA DA CANA DE AÇÚCAR. Bagaço de cana pode ganhar valor substituindo areia na construção civil - Unica. Disponível em: <http://www.unica.com.br/noticia/33630022920327850689/bagaco-de-cana-podeganhar-valor-substituindo-areia-na-construcao-civil/>. Acesso em: 7 maio. 2015b.

VAN MARIS, A. J. A et al. Alcoholic fermentation of carbon sources in biomass hydrolysates by Saccharomyces cerevisiae: current status. Antonie van Leeuwenhoek, v. 90, n. 4, p. 391-418, nov. 2006.

VAN MARIS, A. J. A et al. Development of efficient xylose fermentation in Saccharomyces cerevisiae: xylose isomerase as a key component. Advances in biochemical engineering/biotechnology, v. 108, n. April, p. 179-204, jan. 2007.

VAN VLEET, J. H.; JEFFRIES, T. W. Yeast metabolic engineering for hemicellulosic ethanol production. Current Opinion in Biotechnology, v. 20, n. Figure 1, p. 300-306, 2009.

VASAVADA, N. One-way ANOVA with post-hoc Tukey HSD Calculator. Disponível em: <http://statistica.mooo.com/>. Acesso em: 17 mar. 2015.

WALFRIDSSON, M. et al. Ethanolic fermentation of xylose with Saccharomyces cerevisiae harboring the Thermus thermophilus xylA gene, which expresses an active xylose (glucose) isomerase. Applied and Environmental Microbiology, v. 62, n. 12, p. 4648-4651, 1996. 


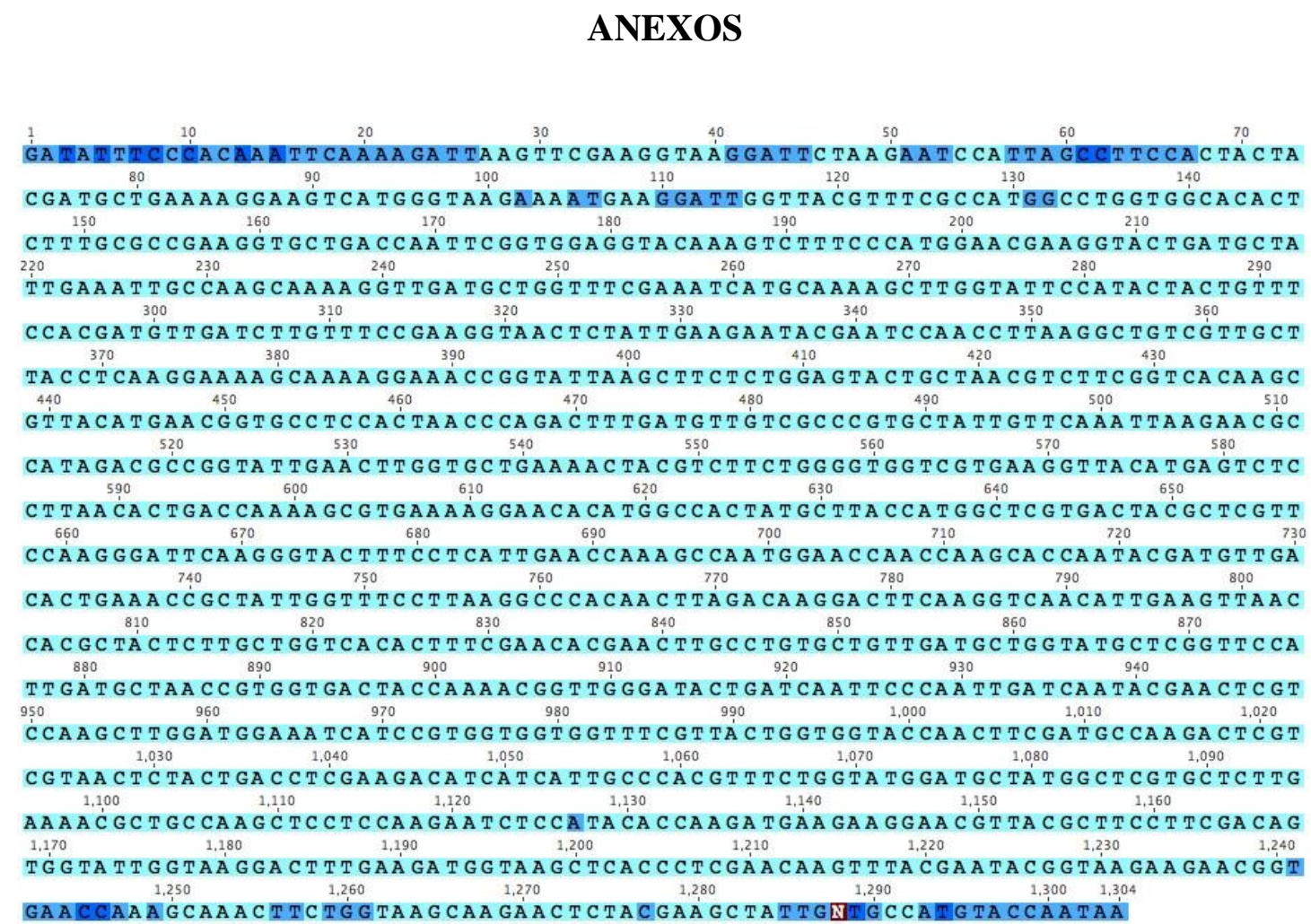

Figura 21: Sequência gerada a partir da montagem de contigs do sequenciamento do

plasmídeo p424-XI originalmente construído para transformação de linhagens, com par de oligonucleotídeos 11/12. 


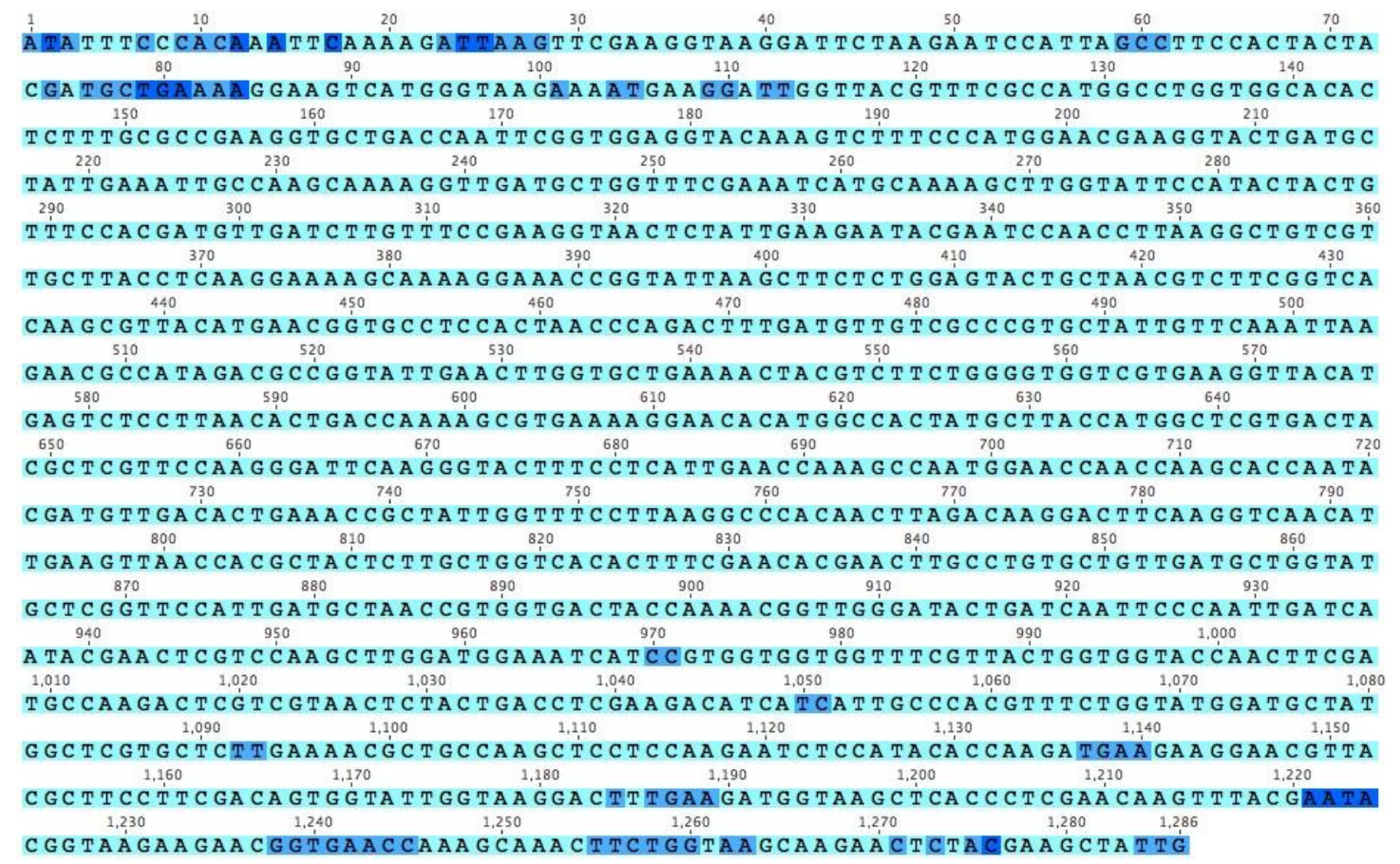

Figura 22: Sequência gerada a partir montagem de contigs do sequenciamento da PCR de XIPiro utilizando plasmídeo extraído da levedura L2XI Condicionada como molde com par de oligonucleotídeos 11/12. 


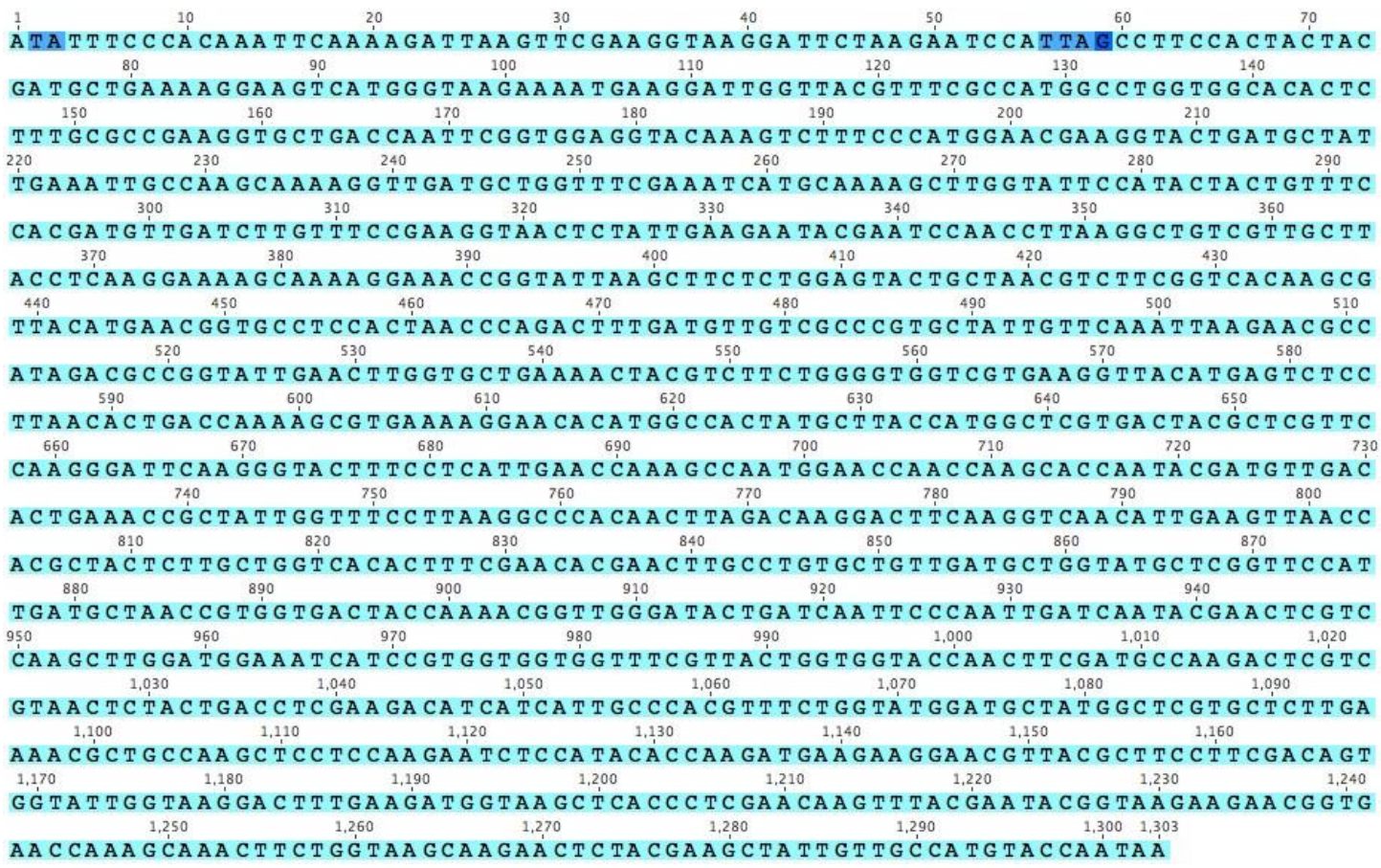

Figura 23: Sequência gerada a partir montagem de contigs do sequenciamento de XIPiro dos plasmídeos A B, C, D e E extraídos das colônias de E. coli transformadas com plasmídeo da levedura L7XIФ Condicionada, com par de oligonucleotídeos 11/12. 


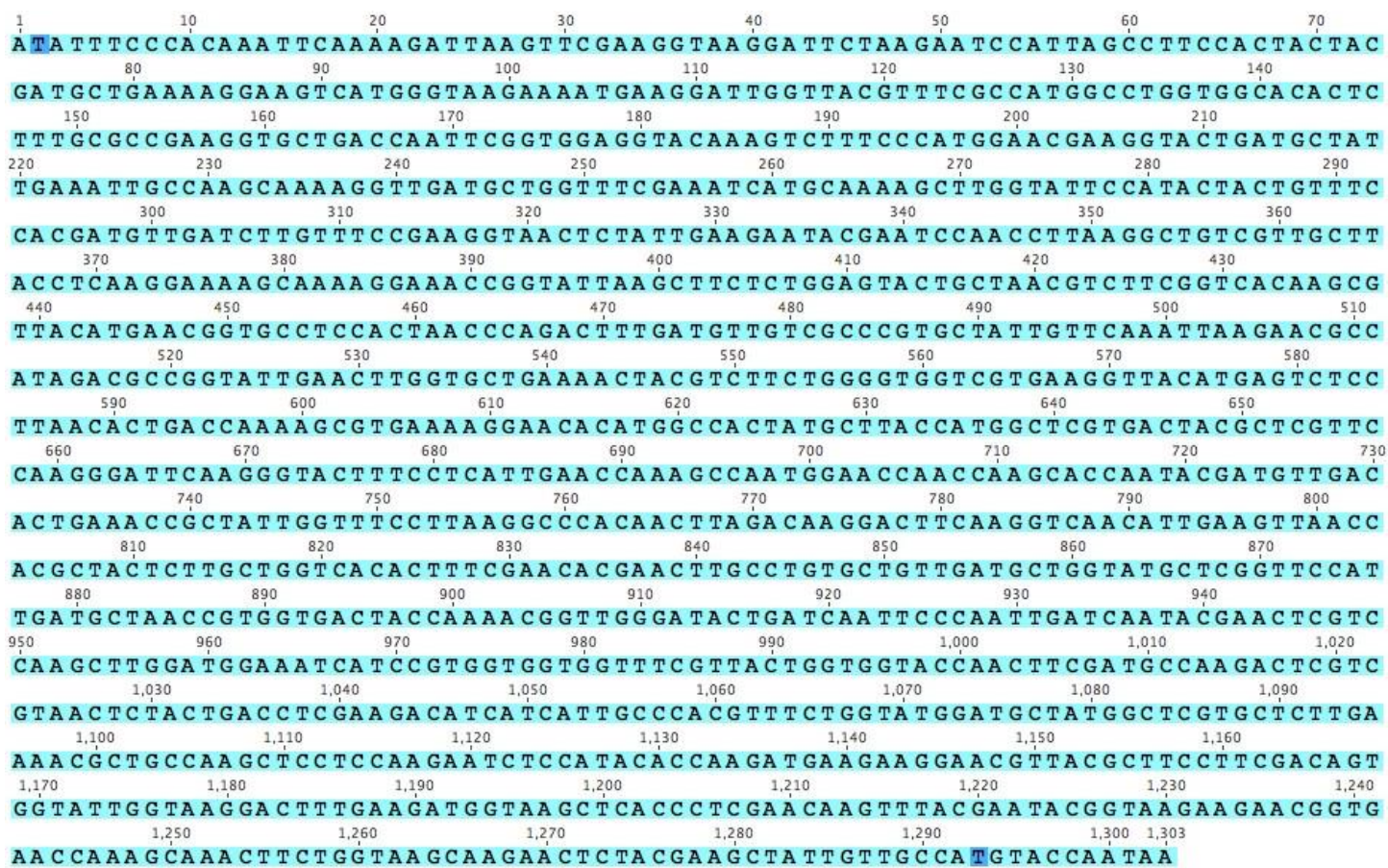

Figura 24: Sequência gerada a partir montagem de contigs do sequenciamento de XIPiro dos plasmídeos A B, C, D e F extraídos das colônias de E. coli transformadas com plasmídeo da levedura L7XIXK Condicionada, com par de oligonucleotídeos $11 / 12$ 
L $2 X I$ consensus sequence

P424XI Controle consensus sequence

L7XI0 consensus sequence

L 7XIXK consensus sequence

L2XI consensus sequence

P424XI Controle consensus sequence

L7XI0 consensus sequence

L 7XIXK consensus sequence

L $2 X I$ consensus sequence

P424XI Controle consensus sequence

L7XI0 consensus sequence

L7XIXK consensus sequence

L $2 X I$ consensus sequence p424XI Controle consensus sequence L 7XI0 consensus sequence

L7XIXK consensus sequence

L $2 X I$ consensus sequence

P424XI Controle consensus sequence

L 7XI0 consensus sequence

L 7XIXK consensus sequence

L $2 X I$ consensus sequence

P424XI Controle consensus sequence

L7XI0 consensus sequence

L 7XIXK consensus sequence

L2XI consensus sequence

P424XI Controle consensus sequence

L 7XI0 consensus sequence

L 7XIXK consensus sequence

L $2 X I$ consensus sequence

P424XI Controle consensus sequence

L7XI0 consensus sequence

L 7XIXK consensus sequence

L 2XI consensus sequence

P424XI Controle consensus sequence

L 7XI0 consensus sequence

L7XIXK consensus sequence

L $2 X I$ consensus sequence

P424XI Controle consensus sequence

L 7XI0 consensus sequence

L7XIXK consensus sequence

L2XI consensus sequence

P424XI Controle consensus sequence

L 7XI0 consensus sequence

L 7XIXK consensus sequence $\begin{array}{lllllll}1 & 10 & 20 & 30 & 40 & 50 & \text { 6C } \\ \text {-ATATTNCCNNCAAATTCAAAN-GATTAAGTTCGAAGGTAAGGATTCTAAGAATCCATTA }\end{array}$ GATATTNCCNNCAAATTCAAAA-GATTAAGTTCGAAGGTAAGGATTCTAAGAATCCATTA -ATATTTCCCNCAAATTCAAAANGATTAAGTTCGAAGGTAAGGATTCTAAGAATCCATTA -ATATTTCCNACAAATTCAAAA-GATTAAGTTCGAAGGTAAGGATTCTAAGAATCCATTA

-GCCTTCCACTACTACGATGCTGAAAAGGAAGTCATGGGTAAGAAAATGAAGGATTGGTI -GCCTTCCACTACTACGATGCTGAAAAGGAAGTCATGGGTAAGAAAATGAAGGATTGGTT SNCCTTCCACTACTACGATGCTGAAAAGGAAGTCATGGGTAAGAAAATGAAGGATTGGTT -GCCTTCCACTACTACGATGCTGAAAAGGAAGTCATGGGTAAGAAAATGAAGGATTGGTI

ACGTTTCGCCATGGCCTGGTGGCACACTCTTTGCGCCGAAGGTGCTGACCAATTCGGTGG ACGTTTCGCCATGGCCTGGTGGCACACTCTTTGCGCCGAAGGTGCTGACCAATTCGGTGG ACGTTTCGCCATGGCCTGGTGGCACACTCTTTGCGCCGAAGGTGCTGACCAATTCGGTGG ACGTTTCGCCATGGCCTGGTGGCACACTCTTTGCGCCGAAGGTGCTGACCAATTCGGTGG

AGGTACAAAGTCTTTCCCATGGAACGAAGGTACTGATGCTATIGAAATTGCCAAGCAAAA AGGTACAAAGTCTTTCCCATGGAACGAAGGTACTGATGCTATTGAAATTGCCAAGCAAAA AGGTACAAAGTCTTTCCCATGGAACGAAGGTACTGATGCTATTGAAATTGCCAAGCAAAA AGGTACAAAGTCTTTCCCATGGAACGAAGGTACTGATGCTATTGAAATTGCCAAGCAAAA

GGTTGATGCTGGTTTCGAAATCATGCAAAAGCTTGGTATTCCATACTACTGTTTCCACGA GGTTGATGCTGGTTTCGAAATCATGCAAAAGCTTGGTATTCCATACTACTGTTTCCACGA GGTTGATGCTGGTTTCGAAATCATGCAAAAGCTTGGTATTCCATACTACTGTTTCCACGA GGTTGATGCTGGTTTCGAAATCATGCAAAAGCTTGGTATTCCATACTACTGTTTCCACGA

TGTTGATCTMGTTCCGAAGGTAACTCTATTGAAGAATACGAATCCAACCTTAAGGCTGT TGTTGATCTTGTTTCCGAAGGTAACTCTATTGAAGAATACGAATCCAACCTTAAGGCTGT TGTTGATCTTGTTTCCGAAGGTAACTCTATTGAAGAATACGAATCCAACCTTAAGGCTGT TGTTGATCTTGTTTCCGAAGGTAACTCTATTGAAGAATACGAATCCAACCTTAAGGCTG

CGTTGCTTACCTCAAGGAAAAGCAAAAGGAAACCGGTATTAAGCTTCTCTGGAGTACTGC CGTTGCTTACCTCAAGGAAAAGCAAAAGGAAACCGGTATTAAGCTTCTCTGGAGTACTGC CGTTGCTTACCTCAAGGAAAAGCAAAAGGAAACCGGTATTAAGCTTCTCTGGAGTACTGC CGTTGCTTACCTCAAGGAAAAGCAAAAGGAAACCGGTATTAAGCTTCTCTGGAGTACTGC

TAACGTCTTCGGTCACAAGCGTTACATGAACGGTGCCTCCACTAACCCAGACTTTGATGT TAACGTCTTCGGTCACAAGCGTTACATGAACGGTGCCTCCACTAACCCAGACTTTGATGT TAACGTCTTCGGTCACAAGCGTTACATGAACGGTGCCTCCACTAACCCAGACTTTGATGT TAACGTCTICGGTCACAAGCGTTACATGAACGGTGCCTCCACTAACCCAGACTTTGATGT

TGTCG-CCCGTGCTATTGTTCAAATTAAGAACGCCATAGACGCCGGTATTGAACTTGGTG TGTCG-CCCGTGCTATTGTTCAAATTAAGAACGCCATAGACGCCGGTATTGAACTTGGTG TGTCGNCCCGTGCTATTGTTCAAATTAAGAACGCCATAGACGCCGGTATTGAACTTGGTG TGTCG-CCCGTGCTATTGTTCAAATTAAGAACGCCATAGACGCCGGTATTGAACTTGGTG

CTGAAAACTACGTCTTCTGGGGTGGTCGTGAAGGTTACATGAGTCTCCTTAACACTGACC CTGAAAACTACGTCTTCTGGGGTGGTCGTGAAGGTTACATGAGTCTCCTTAACACTGACC CTGAAAACTACGTCTTCTGGGGTGGTCGTGAAGGTTACATGAGTCTCCTTAACACTGACC CTGAAAACTACGTCTTCTGGGGTGGTCGTGAAGGTTACATGAGTCTCCTTAACACTGACC

AAAAGCGTGAAAAGGAACACATGGCCACTATGCTTACCATGGCTCGTGACTACGCTCGTI AAAAGCGTGAAAAGGAACACATGGCCACTATGCTTACCATGGCTCGTGACTACGCTCGTT AAAAGCGTGAAAAGGAACACATGGCCACTATGCTTACCATGGCTCGTGACTACGCTCGTT AAAAGCGTGAAAAGGAACACATGGCCACTATGCTTACCATGGCTCGTGACTACGCTCGTI 
L $2 \mathrm{XI}$ consensus sequence P424XI Controle consensus sequence L7XI0 consensus sequence L 7XIXK consensus sequence

L2XI consensus sequence P424XI Controle consensus sequence L7XI0 consensus sequence L7XIXK consensus sequence

L2XI consensus sequence P424XI Controle consensus sequence L7XI0 consensus sequence

L 7XIXK consensus sequence

L 2XI consensus sequence P424XI Controle consensus sequence L $7 X I 0$ consensus sequence

L7XIXK consensus sequence

L2XI consensus sequence

P424XI Controle consensus sequence L 7XI0 consensus sequence

L7XIXK consensus sequence

L2XI consensus sequence P424XI Controle consensus sequence L7XI0 consensus sequence L7XIXK consensus sequence

L $2 X I$ consensus sequence P424XI Controle consensus sequence L7XI0 consensus sequence L 7 XIXK consensus sequence

L2XI consensus sequence P424XI Controle consensus sequence L7XI0 consensus sequence L7XIXK consensus sequence

L2XI consensus sequence P424XI Controle consensus sequence L 7 XI0 consensus sequence L7XIXK consensus sequence

L $2 \mathrm{XI}$ consensus sequence P424XI Controle consensus sequence L7XI0 consensus sequence

L 7XIXK consensus sequence

L2XI consensus sequence P424XI Controle consensus sequence L7XI0 consensus sequence L 7XIXK consensus sequence
CCAAGGGATTCAAGGGTACTTTCCTCATTGAACCAAAGCCAATCGAACCAACCAAGCACC CCAAGGGATTCAAGGGTACTTTCCTCATTGAACCAAAGCCAATGGAACCAACCAAGCACC CCAAGGGATTCAAGGGTACTTTCCTCATTGAACCAAAGCCAATGGAACCAACCAAGCACC CCAAGGGATTCAAGGGTACTTTCCTCATTGAACCAAAGCCAATGGAACCAACCAAGCACC

AATACGATGTTGACACTGAAACCGCTATTGGTTTCCTTAAGGCCCACAACTTAGACAAGG AATACGATGTTGACACTGAAACCGCTATTGGTTTCCTTAAGGCCCACAACTTAGACAAGG AATACGATGTTGACACTGAAACCGCTATTGGTTTCCTTAAGGCCCACAACTTAGACAAGG AATACGATGTIGACACTGAAACCGCTATTGGTTCCTIAAGGCCCACAACTTAGACAAGC

ACTTCAAGGTCAACATTGAAGTTAACCACGCTACTCTTGCTGGTCACACTTTCGAACACC ACTTCAAGGTCAACATTGAAGTTAACCACGCTACTCTTGCTGGTCACACTTTCGAACACC ACTTCAAGGTCAACATTGAAGTTAACCACGCTACTCTTGCTGGTCACACTTTCGAACACG ACTTCAAGGTCAACATTGAAGTTAACCACGCTACTCTTGCTGGTCACACTTTCGAACACG

AACTTGCCTGTGCTGTTGATGCTGGTATGCTCGGTTCCATTGATGCTAACCGTGGTGACI AACTTGCCTGTGCTGTTGATGCTGGTATGCTCGGTTCCATTGATGCTAACCGTGGTGACT AACTTGCCTGTGCTGTTGATGCTGGTATGCTCGGTTCCATTGATGCTAACCGTGGTGACT AACTTGCCTGTGCTGTTGATGCTGGTATGCTCGGTTCCATTGATGCTAACCGTGGTGACT

ACCAAAACGGTTGGGATACTGATCAATTCCCAATTGATCAATACGAACTCGTCCAAGCTT ACCAAAACGGTTGGGATACTGATCAATTCCCAATTGATCAATACGAACTCGTCCAAGCT ACCAAAACGGTTGGGATACTGATCAATTCCCAATTGATCAATACGAACTCGTCCAAGCT? ACCAAAACGGTTGGGATACTGATCAATTCCCAATTGATCAATACGAACTCGTCCAAGCTT

GGATGGAAATCATCCGTGGTGGTGGTTTCGTTACTGGTGGTACCAACTTCGATGCCAAGA GGATGGAAATCATCOGTGGTGGTGGTTCGTACTGGTGGTACCAACTTCGATGCCAAGA GGATGGAAATCATCOGTGGTGGTGGTTTCGTTACTGGTGGTACCAACTTCGATGCCAAGA GGATGGAAATCATCCGTGGTGGTGGTTCGTTACTGGTGGTACCAACTTCGATGCCAAGA

CTCGTCGTAACTCTACTGACCTCGAAGACATCATCATTGCCCACGTTTCTGGTATGGATG CTCGTCGTAACTCTACTGACCTCGAAGACATCATCATTGCCCACGTTTCTGGTATGGATG CTCGTCGTAACTCTACTGACCTCGAAGACATCATCATTGCCCACGTTTCTGGTATGGATG CTCGTCGTAACTCTACTGACCTCGAAGACATCATCATTGCCCACGTTTCTGGTATGGATE

CTATGGCTCGTGCTCTTGAAAACGCTGCCAAGCTCCTCCAAGAATCTCCATACACCAAGA CTATGGCTCGTGCTCTTGAAAACGCTGCCAAGCTCCTCCAAGAATCTCCATACACCAAGA CTATGGCTCGTGCTCTTGAAAACGCTGCCAAGCTCCTCCAAGAATCTCCATACACCAAGA CTATGGCTCGTGCTCTTGAAAACGCTGCCAAGCTCCTCCAAGAATCTCCATACACCAAGA

TGAAGAAGGAACGTTACGCTTCCTTCGACAGTGGTATTGGTAAGGACTTTGAAGATGGTA TGAAGAAGGAACGTTACGCTTCCTTCGACAGTGGTATTGGTAAGGACTTTGAAGATGGTA TGAAGAAGGAACGTTACGCTTCCTTCGACAGTGGTATTGGTAAGGACTTTGAAGATGGTA TGAAGAAGGAACGTTACGCTTCCTTCGACAGTGGTATTGGTAAGGACTTTGAAGATGGTA

AGCTCACCCTCGAACAAGTTTACGAATACGGTAAGAAGAACGGTGAACCAAAGCAAACTI AGCTCACCCTCGAACAAGTTTACGAATACGGTAAGAAGAACGGTGAACCAAAGCAAACTT AGCTCACCCTCGAACAAGTTTACGAATACGGTAAGAAGAACGGTGAACCAAAGCAAACT2 AGCTCACCCTCGAACAAGTTTACGAATACGGTAAGAAGAACGGTGAACCAAAGCAAACTT

CTGGTAAGCAAGAACTCTACGAAGCTATTG-

CTGGTAAGCAAGAACTCTACGAAGCTATTGNTGCCATGTACCAATAA

CTGGTAAGCAAGAACTCTACGAAGCTATTGTTGCCATGTACCAATAA

CTGGTAAGCAAGAACTCTACGAAGCTATTGTTGCCATGTACCAATAA

Figura 25: Alinhamento entre sequências obtidas, dos plasmídeos p424-XI, L2XI, L7XIФ e L7XIXK Condicionadas. 